\title{
The Okanogan Subbasin Water Quality and Quantity Report for Anadromous Fish in 2006
}
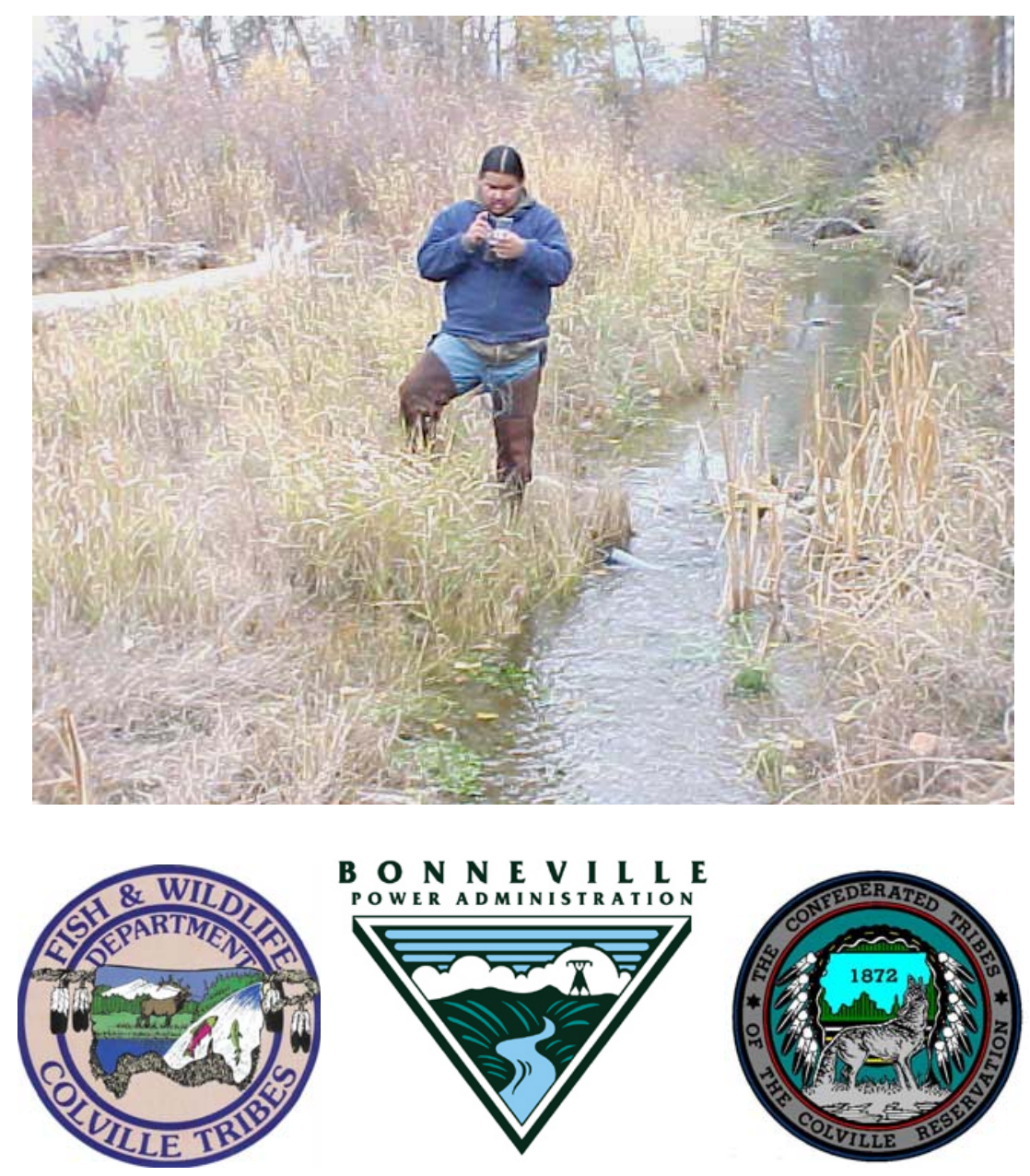

CCT/AF-2007-7

December 2007

\section{COLVILLE TRIBES}

DEPARTMENT OF FISH \& WILDLIFE

ANADROMOUS FISH DIVISION-OMAK OFFICE

\author{
23 Brooks Tracts Road \\ Omak WA 98841 \\ Voice (509) 422-7424 \\ Fax (509) 422-7428
}




\title{
The Okanogan Subbasin Water Quality and Quantity Report for Anadromous Fish in 2006
}

\author{
BPA Project \# 200302200
}

\author{
Prepared by \\ Keith Kistler and John Arterburn
}

Prepared for

U.S. Department of Energy

Bonneville Power Administration

Division of Fish and Wildlife

P.O. Box 3621

Portland, OR 97208-3621

\section{December 2007}




\section{Table of Contents}

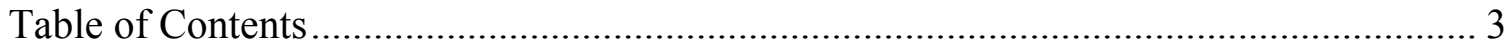

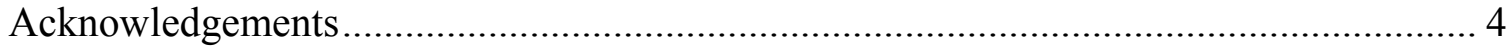

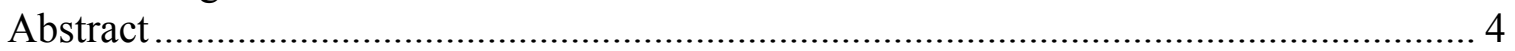

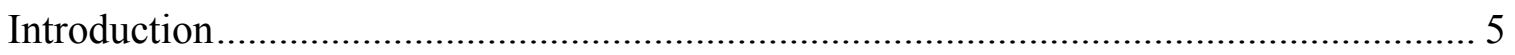

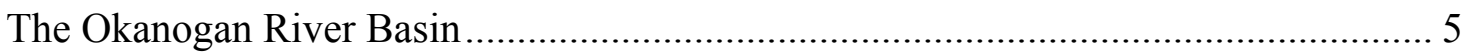

The Fisheries Resource ................................................................................ 5

Historical Data Collection..................................................................................... 5

Expanded monitoring through OBMEP............................................................... 6

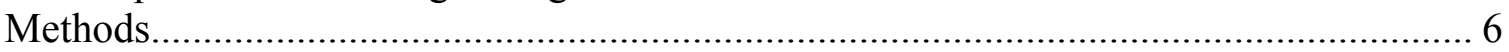

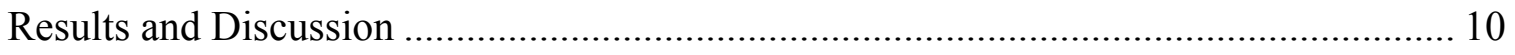

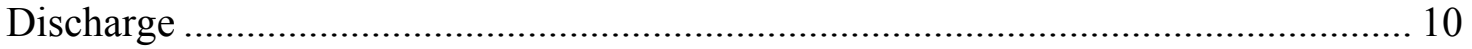

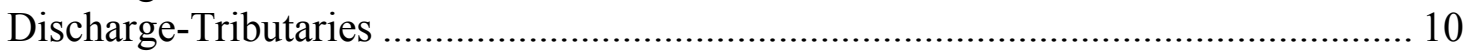

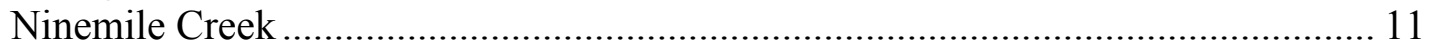

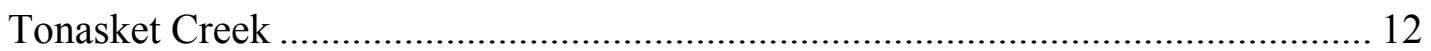

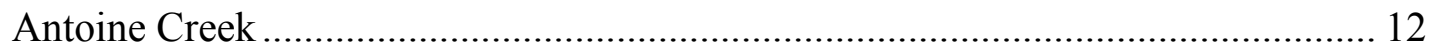

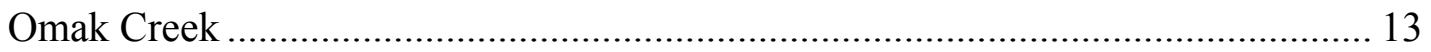

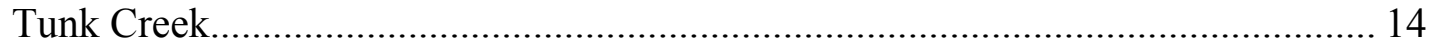

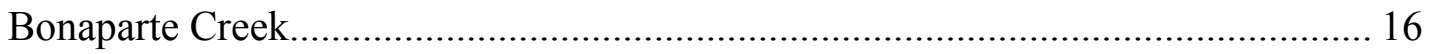

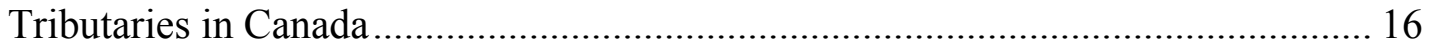

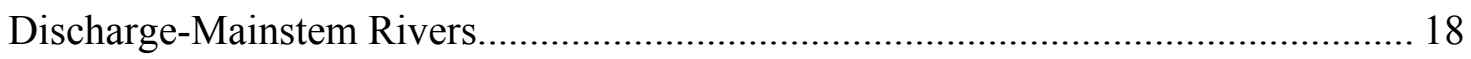

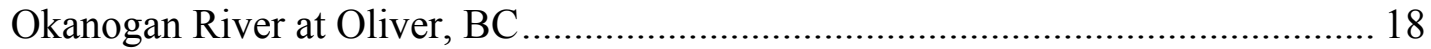

Okanogan River at Oroville, WA .................................................................. 19

Similkameen River at Oroville, WA.................................................................. 20

Okanogan River below the Confluence with the Similkameen River ....................... 20

Twelve Year Discharge trends on the Okanogan and Similkameen Rivers ............. 21

Water Quality indicators other than discharge and temperature................................... 24

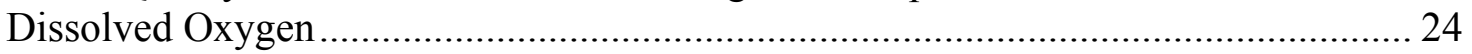

Dissolved Oxygen-Main-stem Status and Trend ................................................ 25

Dissolved Oxygen-Tributary Status.................................................................. 28

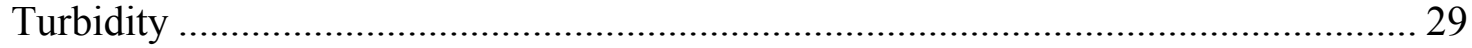

Turbidity-Main-stem Status and Trend.............................................................. 29

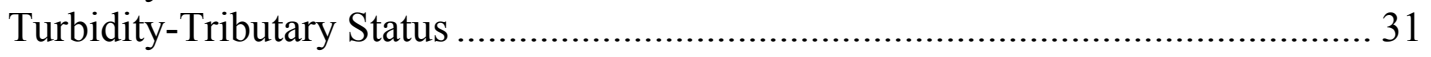

$\mathrm{pH}$

pH-Main-stem Status and Trend .......................................................................... 31

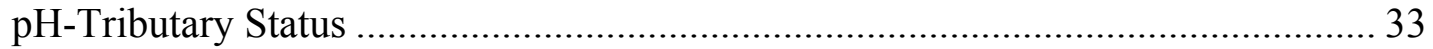

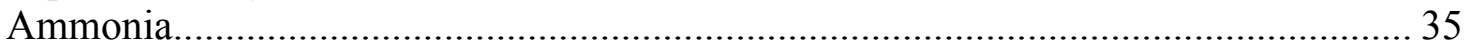

Ammonia-Main-stem Status and Trend.............................................................. 35

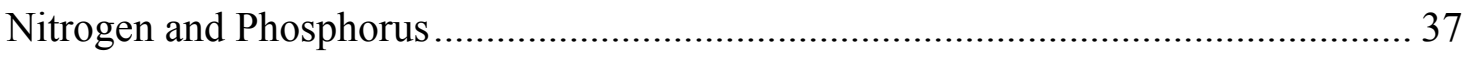

Nitrogen and Phosphorus-Main-stem Status and Trend .......................................... 38

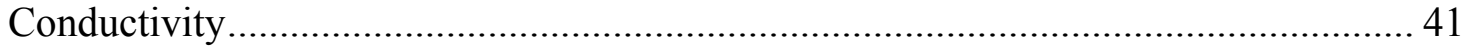

Conductivity-Main-stem Status and Trend .......................................................... 41

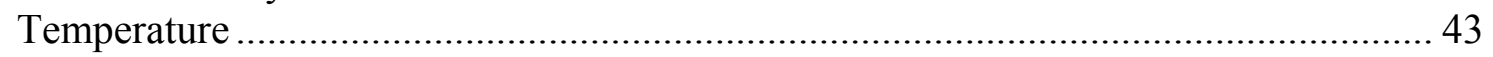

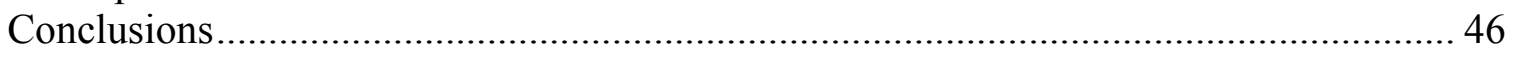

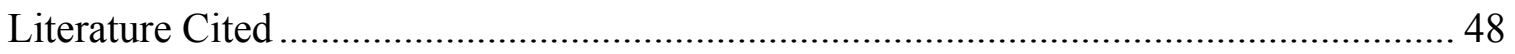




\section{Acknowledgements}

We would like to thank Michael Rayton and Chris Fisher for reviewing this report. Special thanks go out to Sidryn Sam, Tim Erb Jr., Kevin Manuel, Fred Jordan, Ed Berrigan, Richard Tonasket, Jordan Leskinan and Tony Moore for their help in field data collection, entering, and compiling data for this report. The administrative assistance of Joe Peone, Jerry Marco, Loni Seymour, Colette Adolph, Mari Duran, Cindy McCartney, Shelly Davis, and the other Colville Fish and Wildlife Department staff members that helped this project succeed. We also thank: Summit Environmental, BioAnalysts, Environmental Trust of the Colville Tribes, Okanagan Nation Alliance, Washington State Department of Ecology, Environment Canada and the United States Geological Survey for their data collection efforts and willingness to share their data.

The Okanogan Basin Monitoring and Evaluation Program (OBMEP) is funded by Bonneville Power Administration (BPA). We thank BPA staff Sarah Branum, Christine L. Read, and Kimberly R. St Hilaire for their support and cooperation with various parts of this project.

\section{Abstract}

Fish need water of sufficient quality and quantity in order to survive and reproduce. The list of primary water quality indicators appropriate for monitoring of anadromous fish, as identified by the Upper Columbia Monitoring Strategy, includes: discharge, temperature, dissolved oxygen, $\mathrm{pH}$, turbidity, conductivity, nitrogen, phosphorus and ammonia.

The Colville Tribes' Fish and Wildlife Department began evaluating these water quality indicators in 2005 and this report represents data collected from October 1, 2005 through September 30, 2006. We collected empirical status and trend data from various sources to evaluate each water quality indicator along the main stem Okanogan and Similkameen Rivers along with several tributary streams. Each water quality indicator was evaluated based upon potential impacts to salmonid survival or productivity. Specific conductance levels and all nutrient indicators remained at levels acceptable for growth, survival, and reproduction of salmon and steelhead. These indicators were also considered of marginal value for monitoring environmental conditions related to salmonids within the Okanogan subbasin. However, discharge, temperature, turbidity, dissolved oxygen and $\mathrm{pH}$ in that order represent the water quality indicators that are most useful for monitoring watershed health and habitat changes and will help to evaluate threats or changes related to salmon and steelhead restoration and recovery. On the Okanogan River minimum flows have decreased over the last 12 years at a rate of $-28.3 \mathrm{CFS} /$ year as measured near the town of Malott, WA. This trend is not beneficial for salmonid production and efforts to reverse this trend should be strongly encouraged. Turbidity levels in Bonaparte and Omak Creek were a concern because they had the highest monthly average readings. Major upland disturbance in the Bonaparte Creek watershed has occurred for decades and agricultural practices within the riparian areas along this creek have lead to major channel incision and bank instability. High sediment loads continue to threaten Omak and Bonaparte subwatersheds. Major rehabilitation efforts are needed within these sub-watersheds to improve salmonid habitats. We found that for the past 12 years dissolved oxygen levels have been on a slightly downward trend during summer/fall Chinook egg incubation. Dissolved oxygen readings in early October, for summer/fall Chinook and from June 
through early July for summer steelhead can occasionally drop to the range from 8 to 10 $\mathrm{mg} / \mathrm{L}$ and therefore warrant continued monitoring. Levels of $\mathrm{pH}$ represent an indicator that has little monitoring value throughout most of the subbasin. The Similkameen River drainage showed dramatic annual changes in the mean $\mathrm{pH}$ values and a declining trend for $\mathrm{pH}$ thus warranting continued monitoring. Average daily temperatures, in 2006, exceeded $25^{\circ} \mathrm{C}$ for eight days in July in the Okanogan River at Malott. Due to increased warm water temperatures, delays in migration have increased at a rate of 1.82 days per year over the last 10 years. Increases in water temperature can be linked to many anthropogenic activities. Increasing water temperatures within the Okanogan River watershed represent the single most limiting factor facing salmonids in main-stem habitats.

\section{Introduction}

\section{The Okanogan River Basin}

The Okanogan River watershed covers approximately 2,123,800 hectares. The confluence with the Columbia River is located in north-central Washington State, but $70 \%$ of the watershed is located in Canada. The Okanogan River is like two rivers in one: the United States (US) portion of the river is strongly influenced by the Similkameen River, which provides most of the water and sediment from a flashy, snowmelt-driven watershed; while the Okanagan River above the Similkameen confluence provides a lesser quantity of water from a stable, clear, lake-drained watershed.

\section{The Fisheries Resource}

The Okanogan River is the most northern watershed accessible to anadromous fish in the entire Columbia River basin. Due to an extremely low gradient, high water temperatures during summer months and turbid water, the habitat in the mainstem Okanogan River differs greatly from the traditional environments most people consider ideal for anadromous fish production. Returning fish must transverse nine major hydroelectric dams and several smaller impediments. Many tributary streams of the Okanogan basin have been diverted in part or whole to support the agrarian economy of the region. In spite of all this, a healthy stock of summer Chinook, and the most robust stock of sockeye salmon remaining in the Columbia River Basin call the Okanogan River home along with endangered summer steelhead.

\section{$\underline{\text { Historical Data Collection }}$}

The Washington State Department of Ecology (WDOE) has collected monthly water quality grab samples along the mainstem Okanogan and Similkameen Rivers for many years. The United States Geological Survey (USGS) and Environment Canada have collected discharge information along the main-stem Okanogan and Similkameen Rivers for many years. Recognizing the importance of monitoring discharge and temperature, WDOE expanded their data collection efforts to a select group of tributary streams beginning in 1997. Discharge and temperature data collection has also expanded due to the Okanogan Basin Monitoring and Evaluation Program (OBMEP) since 2004. Water quality information on tributary streams of the US and Canadian portions of the 
Okanogan basin had not expanded beyond the main-stem reaches until the efforts of OBMEP in 2005.

\section{Expanded monitoring through OBMEP}

OBMEP was developed in an attempt to improve our understanding of the anadromous fish populations and habitat that exists within the Okanogan River basin. The water quality/quantity and temperature part of OBMEP is designed to document water quality, discharge and temperature changes over time by addressing the question: is there a statistically significant difference in selected water quality parameters for the Okanogan basin over time (7-20+ year time frame).

Since 2004, the Okanogan Basin Monitoring and Evaluation Program (OBMEP) has contributed monetarily to the collection of real time temperature data at the USGS flow monitoring sites along the main-stem Okanogan River. Additionally, since 2005, this project has installed new real-time discharge and temperature gauging stations in four tributaries throughout the US and Canada. Temperature and discharge data will continue to be collected in future years by the Colville Tribes in cooperation with USGS, Environment Canada, and WDOE until 2024 or as long as funding is continued.

In March of 2005, OBMEP began water quality surveys throughout the US. Twenty-five sites were surveyed for dissolved oxygen, $\mathrm{pH}$, specific conductivity, turbidity and temperature. Water quality surveys occurred three times a month at tributary and selected main-stem sites. Data was collected at nineteen sites on small tributary streams and five sites on the main-stem Okanogan River, and one site on the Similkameen River.

In 2006, twenty-five sites were surveyed in the US including; 19 sites on small tributary streams and 5 sites on the Okanogan River with 1 site on the Similkameen River. An additional 16 sites were monitored in Canada by the Okanagan Nation Alliance (ONA.) including; 12 sites on small tributary streams and 4 sites on the main-stem Okanagan River (Benson et al 2006). These OBMEP water quality surveys were concluded at the end of February 2007 due to a lack of funding provided from the Northwest Power and Conservation Council and Bonneville Power Administration. The Colville Tribes hope to reinstate these data collection activities in the near future if alternative funding can be secured.

\section{$\underline{\text { Methods }}$}

Water Quality and temperature data was collected in 2006 at all EMAP sites located on tributary streams of the Okanogan River as identified in the Colville Tribes physical habitat protocol (Arterburn et al. 2006). Discharge, Temperature, and water quality data was gathered from WDOE, Environment Canada, and USGS real-time gauging locations along the Okanogan and Similkameen Rivers (Figures 1\&2). Temperature data was also collected at all tributary EMAP sites by OBMEP, these data will be complied into a future report. Limited temperature data was compiled for this report primarily for the purpose of explaining results of other water quality indicators that are covariates with temperature. 
Water Quality data collected as part of the OBMEP by the Colville Tribes in the US or the ONA in Canada follows specific protocols (Arterburn et al. 2005). The Colville Tribes water quality protocols were developed to be consistent with, but expand from, the Upper Columbia strategies (Hillman 2006). The OBMEP water quality protocols can be viewed at: (http://nrd.colvilletribes.com/obmep/Reports.htm). The Colville Tribes and ONA collected $\mathrm{pH}$, conductivity, dissolved oxygen, and turbidity data using a Eureka Manta ${ }^{\circledR}$ water quality probe coupled to a Eureka Amphibian ${ }^{\circledR}$ field recorder.

Measurements at each site were collected three times per month.

Discharge grab samples were measured at the downstream extent of Ninemile Creek, Tonasket Creek, and Antoine Creek. Discharge garb samples were not collected on a consistent basis but rather haphazardly. The Okanogan Conservation District and WDOE are primarily responsible for these data but the Colville Tribes are attempting to supplement this information through a coordinated effort when crews are available to do so. When collecting discharge data we used a Marsh-McBirney Flo-Mate model 2000. The Flo-Mate measures flow using the Faraday law of electromagnetic induction. This law states that as a conductor moves through a magnetic field, a voltage is produced. The magnitude of this voltage is directly proportional to the velocity at which the conductor moves through the magnetic field. We divided the width of the channel into equal segments, did a velocity profile and calculated the flow for each segment and finally summed the segment flows for the total flow.

Water quality data was compiled from WDOE's four real-time flow monitoring stations, three periodic grab sample stations and three water quality grab sample stations within the Okanogan River basin following the Quality Assurance Monitoring Plan for a streamflow Gauging Network (Butkus 2005). OBMEP compiled discharge and temperature data from the USGS at three flow and temperature monitoring sites on the Okanogan River and one on Ninemile Creek. Data collected at these sites follows the protocols outlined in the document titled "Surface-Water Quality-Assurance Plan for the Washington District, U.S. Geological Survey, Water Resources Discipline” (Kresch and Tomlinson 2004).

Environment Canada discharge and temperature data is collected from 4 sites. These realtime data are available on their web site and is fed from both satellite (data collection platforms) and land-line (telephone) transmissions from the hydrometric stations. Satellite transmissions are on a scheduled basis, typically every 1 to 3 hours. Land-line hydrometric stations are polled on a scheduled basis varying from every hour to once a day, depending on the station. The real-time data acquisition and decode is managed by NewLeaf ${ }^{\mathrm{TM}}$. Once data is decoded in NewLeaf ${ }^{\mathrm{TM}}$, it is transferred to an Oracle ${ }^{\mathrm{TM}}$ database which feeds the web site. Data transfer between the two systems occurs on a scheduled basis every hour. 


\section{US Water Quality, Water Quantity and Temperature Survey Sites 2005-2007}

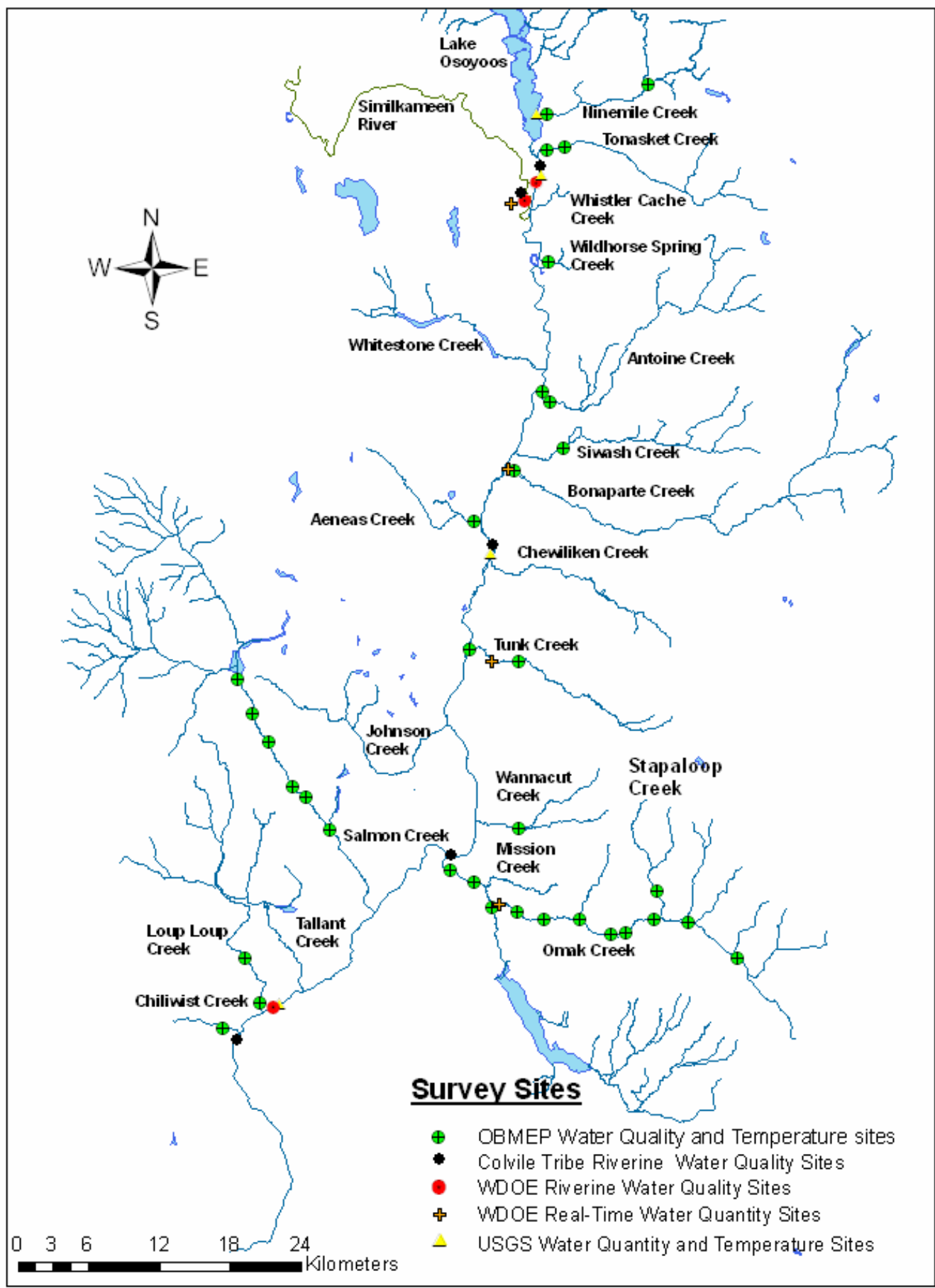

Figure 1: Water quality, quantity, and temperature data collection sites throughout the US portion of the Okanogan Basin, 2005 to 2007. 


\section{Canada Water Quality, Water Quantity and Temperature Survey Sites 2006-2007}

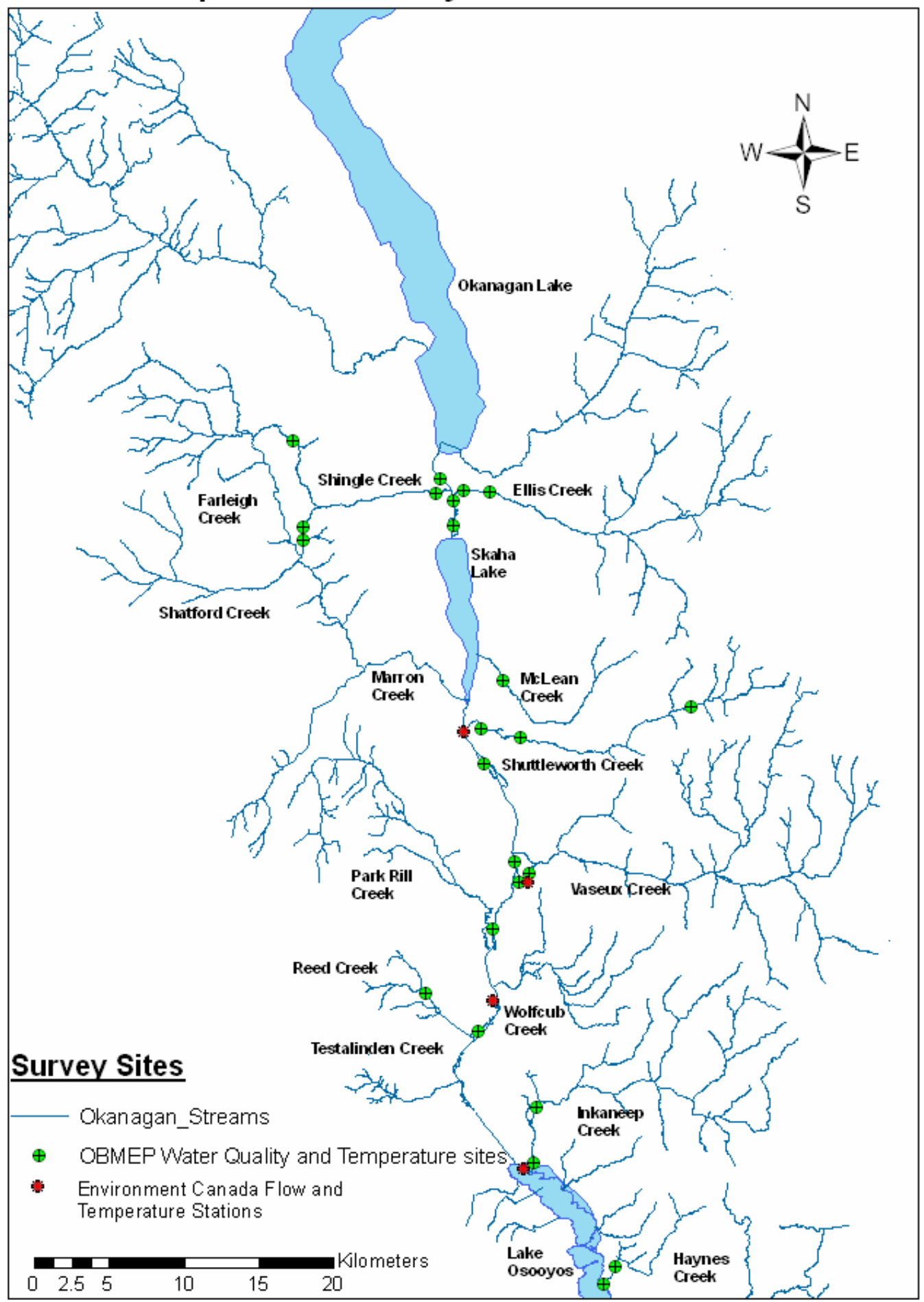

Figure 2: Water quality, quantity, and temperature data collection sites throughout the Canadian portion of the Okanogan Basin, 2005 to 2007. 


\section{$\underline{\text { Results and Discussion }}$}

\section{Discharge}

Discharge impacts survival of salmonids by manifestation of the first law of fisheries which states that; "fish need water". When discharge reaches zero so do the supportable fish populations. At discharge readings above zero the quantity of habitat available is directly related to the amount of discharge and this is especially true during low or base flow periods. In the Okanogan River basin low flow periods typically occur during the months of August and September. During mild or extremely cold winters this low flow period can extend from August all the way through February. Activities that occur during these periods such as spawning, incubation, and juvenile rearing can heavily influence the annual production of summer steelhead and Chinook salmon. The minimum amount of discharge during these life stages influences the maximum amount of habitat available to fish during each of their life stages.

Status data within a given year can be used to help determine; if any production is possible by determining if discharge remained above zero throughout the year and secondly, determine if the amount of habitat available for critical life stages were higher or lower than recent historical averages. Further trend analysis can be used to determine if these conditions only apply to this year or are part of an ongoing issue that is likely to impact the population over the longer-term.

Water quality, discharge, and temperature data presented in this report is for the 2006 water year (October 2005-September 2006) unless otherwise noted. Discharge data is represented in cubic feet per second (CFS) for all US and Canadian sites. Twelve year trend data for discharge was only possible for the USGS gauging station sites along the Okanogan and Similkameen Rivers. Real-time discharge information for Okanogan River tributary streams have only been collected for 4-years therefore no trend analysis was conducted.

\section{Discharge-Tributaries}

Discharge data is divided into two categories; 1) grab sample data that are sporadically collected by measuring width, depth, and velocity then calibrating these measures to a staff gauge and stage discharge curve. Streams where this type of data is collected include Nine-mile Creek, Tonasket Creek, and Antoine Creek. The second category is; 2) Real-time gauging station data that is collected electronically several times each day and is much more accurate and reliable. Streams with real-time gauging stations include; Nine-mile (as of July 2006), Omak, Tunk, and Bonaparte creeks.

In 2006, most tributary streams show low-flow characteristics from August through January in the US portion of the Okanogan River basin. Peak discharges occurred during the months of April and May depending on the size and altitude of the drainage. Low flows in most tributary streams occur during the months of August or September when air temperatures are the highest, precipitation is the least, and irrigation demand is the highest. 


\section{$\underline{\text { Ninemile Creek }}$}

Stream measurements have been taken since 2002 by WDOE https://fortress.wa.gov/ecy/wrx/wrx/flows/station.asp?sta=49J060. Discharge or staff gauge measurements taken when no water was present are extremely rare. However, base flow periods are typically less than 1-CFS. The Colville Tribes in cooperation with the USGS installed a real-time flow and temperature gage at river mile 1.1 of Ninemile Creek. This data began being collected on 7/17/2006 and can be viewed at: http://nwis.waterdata.usgs.gov/nwis/uv?12438900. Comparing data collected from grab samples with that collected at the real-time gauge show good correlation for the short period of overlap.

In 2006, peak discharge was recorded at the WDOE staff gauge on 5/4/2006 at 11.1-CFS. The lowest discharge was recorded for the period from $8 / 15 / 2006$ through $8 / 17 / 2006$ at 0.28 -CFS at the USGS gauging site. However, on $8 / 15 / 2007$ a staff gauge reading at the WDOE site was recorded at $0.7-\mathrm{CFS}$ and this reading represented the largest discrepancy during the entire overlap period to date. Staff gauge readings are much more susceptible to human error and have much more variation when compared to electronic equipment used at the USGS site. We compiled grab sample data collected by WDOE from 2002 to 2006 at the WDOE gauging site and real time data collected by the USGS further upstream (Figure 3). Peak discharge in 2006 was slightly less than twice the average discharge recorded from 2002-2006 with the low discharge period in 2006 being similar to historic averages. Peak discharge occurred in May, 2006 rather than in April, as in previous years. Although minimal, discharge was conducive to salmonid production for the entire period of record from 2002-2006. Efforts to increase discharge would have a positive benefit toward salmonid production especially during the low flow period from mid-June through September when discharge occasionally reaches zero as in 2005.

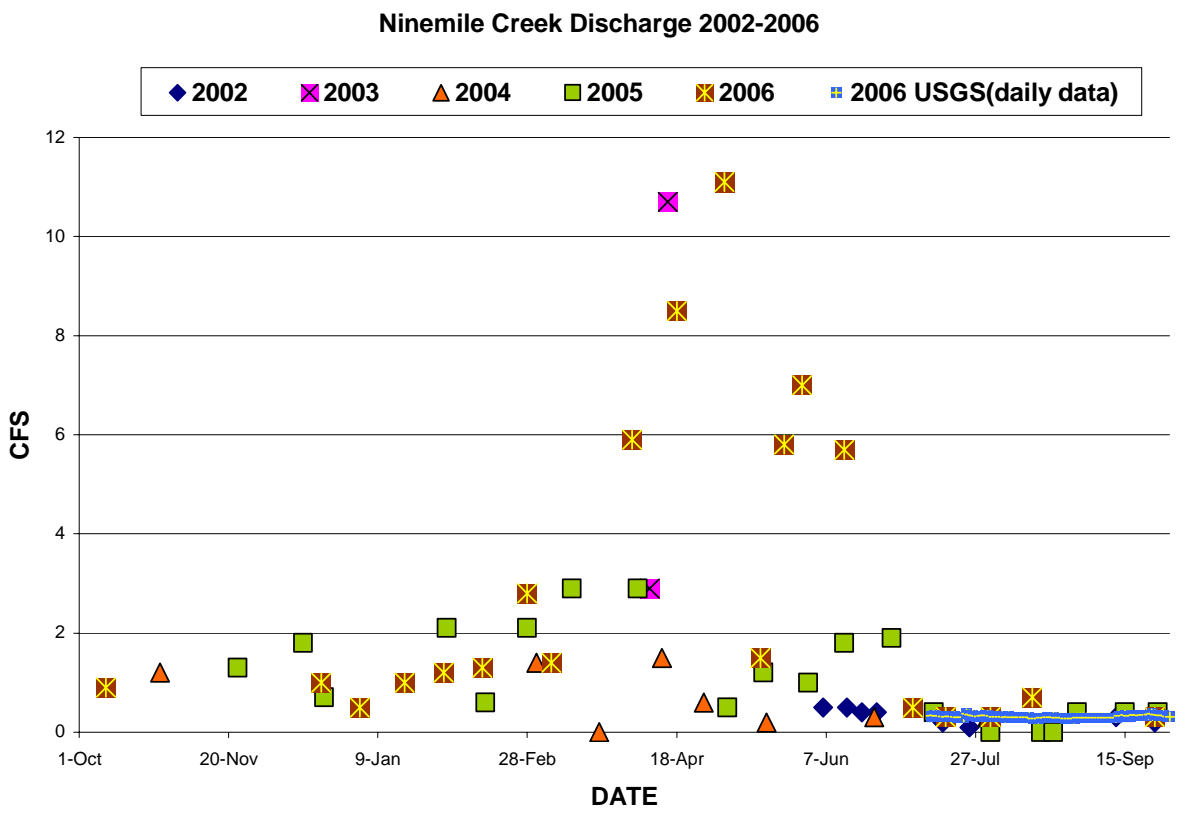

Figure 3: Ninemile Creek discharge showing all data collected in 2002-2006(data from the period of record at this site). 


\section{Tonasket Creek}

Based upon data collected at the WDOE staff gauge, lower Tonasket Creek would be considered intermittent. In most years, water is present from March through July https://fortress.wa.gov/ecy/wrx/wrx/flows/station.asp?sta=49H080. However, very few data points are collected on an annual basis.

In 2006, measurable flows were present prior to 3/7/2006 when the first readings for the water year were taken and after 5/24/2006 when the last readings for the water year were taken (Figure 4). Peak discharge was measured on 5/4/2006 by WDOE personnel at 15.0-CFS. This peak discharge was the highest recorded during the period of record with the next closest value being 12.7-CFS, recorded on 4/15/2003. Although summer steelhead are known to spawn in Tonasket Creek a lack of water throughout most of the year severely limits any opportunity for steelhead smolt production.

\section{$\underline{\text { Antoine Creek }}$}

Antoine Creek is a regulated watershed so discharge measurements are highly influenced by operations at Fancher Dam. Based upon data collected at the WDOE staff gauge, lower Antoine Creek would be considered a perennial stream.

Discharge measurements spanned from 1/3/2006 to 9/25/2006 with base flows of approximately 2 to 3-CFS. Peak discharge was measured on 5/24/2006 by WDOE personnel at 28.4-CFS surpassing the old record discharge of 11.1-CFS taken on $11 / 23 / 2004$. High discharge in 2006, provided rare access to spawning areas for adult summer steelhead and redds were observed (Arterburn and Kistler 2006). However, two data points were collected as a zero in the summer of 2006 (Figure 5) which likely resulted in a loss of summer steelhead production. https://fortress.wa.gov/ecy/wrx/wrx/flows/station.asp?sta=49G060. Preliminary information suggests that with improved water management sufficient water quality and quantity would exist for consistent summer steelhead spawning and smolt production. 
Tonasket Creek Discharge 2002-2006

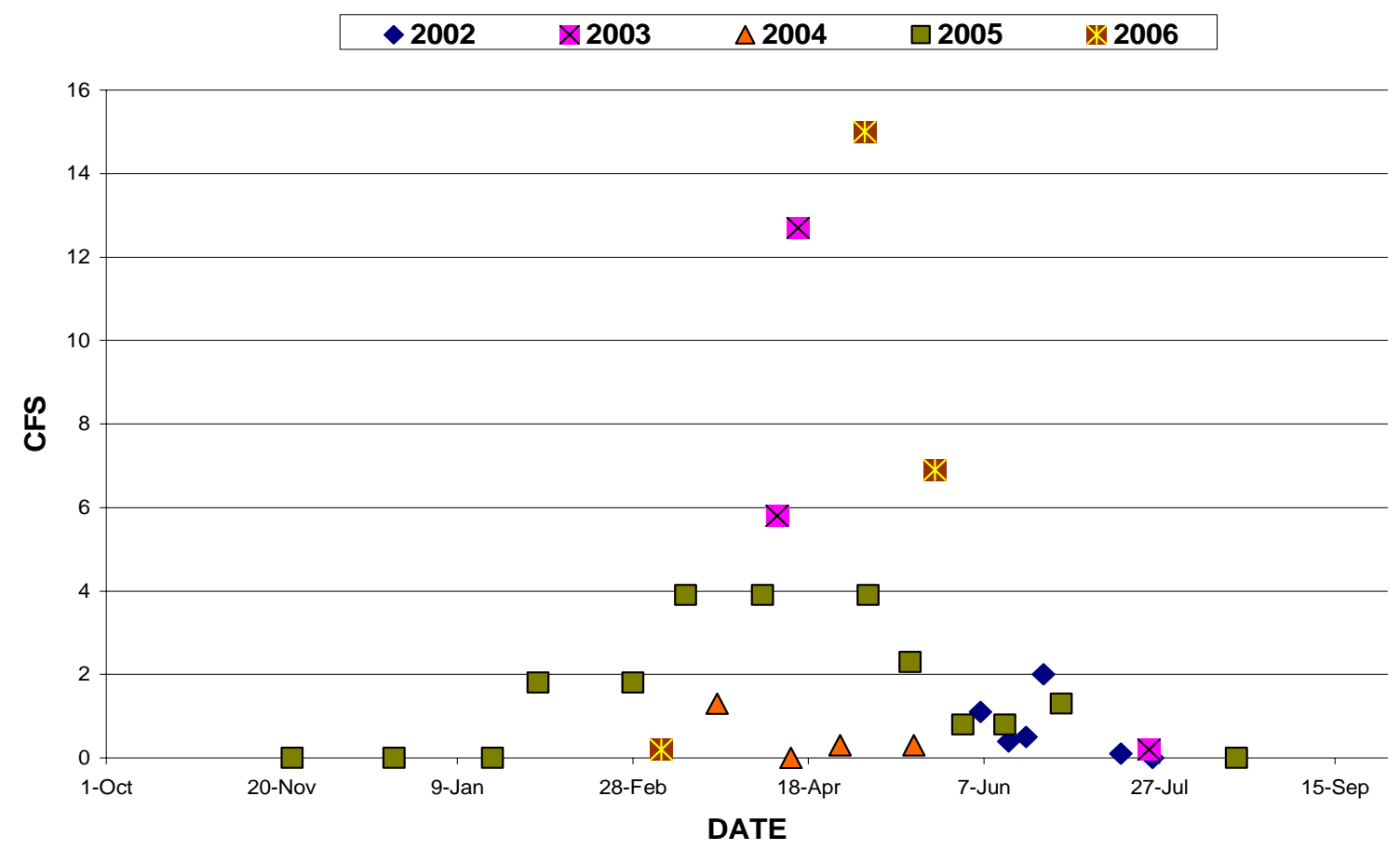

Figure 4: Tonasket Creek daily discharge comparing data collected from 2002-2006 data for the period of record at this site.

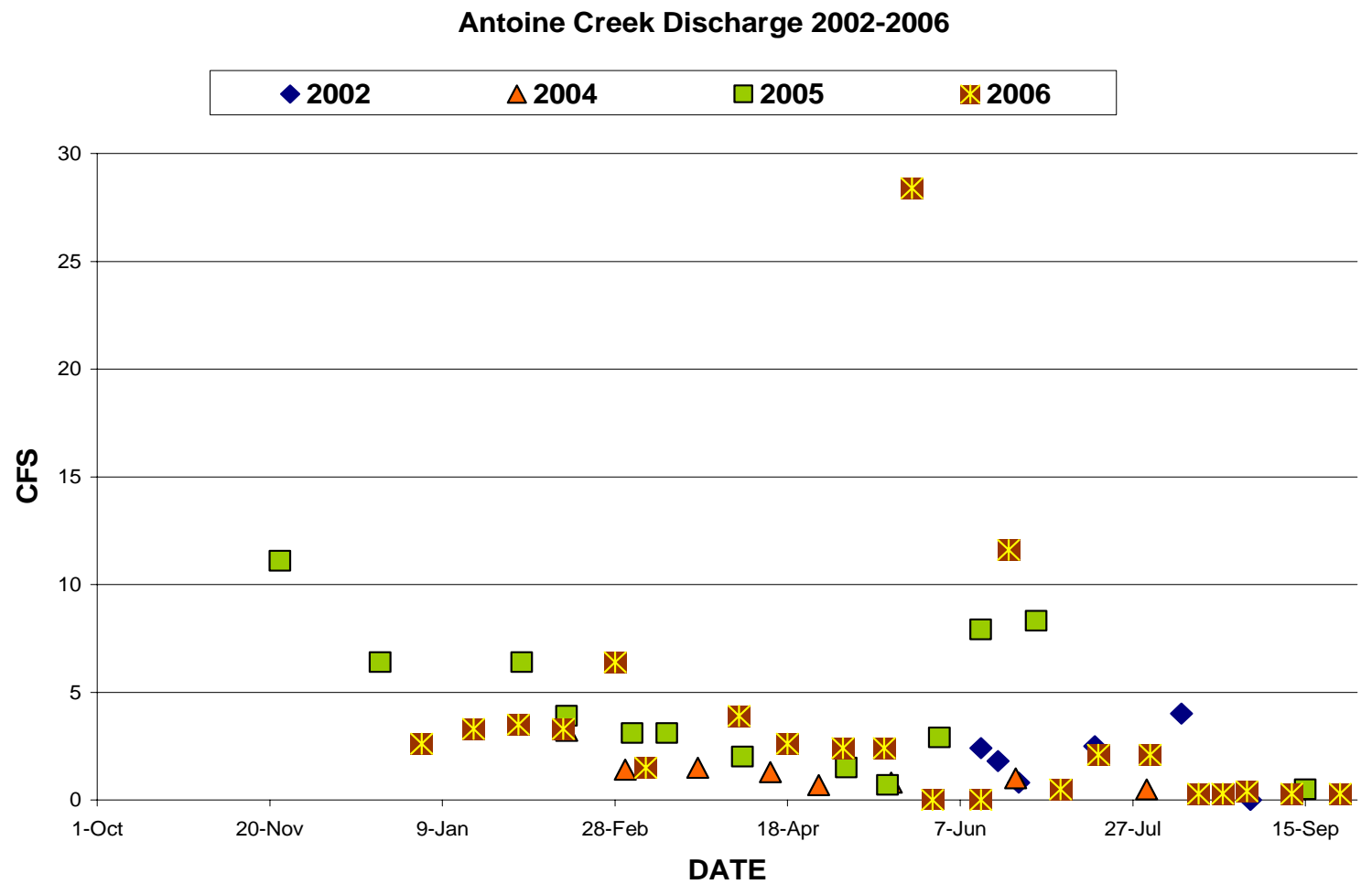

Figure 5: Antoine Creek daily discharge comparing data collected from 2002-2006

$\underline{\text { Omak Creek }}$ 
A review of past discharge data suggest that Omak Creek is a perennial stream https://fortress.wa.gov/ecy/wrx/wrx/flows/station.asp?sta=49C100. Discharge data collected for Omak Creek is monitored by WDOE at a real-time telemetry gauging station located near the Saint Mary's Mission. Discharge and temperature data have been recorded consistently at this site since 2003. The hydrograph of Omak Creek typically shows a narrow high flow peak (April) with rapidly increasing (March)/decreasing (May) limbs and base flows that typically range from 3-4 CFS in August and September (Figure $6)$.

In 2006, a record peak mean daily discharge was measured on 4/9/2006 at 228-CFS with an instantaneous peak of 283-CFS. The previous record discharge was measured on $4 / 25 / 2003$ at $195-$ CFS with an instantaneous peak of 227-CFS. The lowest discharge measured in 2006 was $1.7-$ CFS on 10/1/2006 which was well above the minimum discharge record in both 2004 and 2005 of 0.7-CFS. High spring discharge provided good access to spawning habitats for adult salmonids and good base flows of between 3-4 CFS provide for plentiful rearing habitat. Because 2006, was a good water year summer steelhead smolt production was likely higher than it has been for the last couple of years. Increased summer steelhead smolt production likely benefited from flows being maintained throughout the year along the lower mile of Omak Creek during the months of August and September. In 2004 and 2005 the lower mile section went dry. Missing data was due to malfunctions caused by ice.

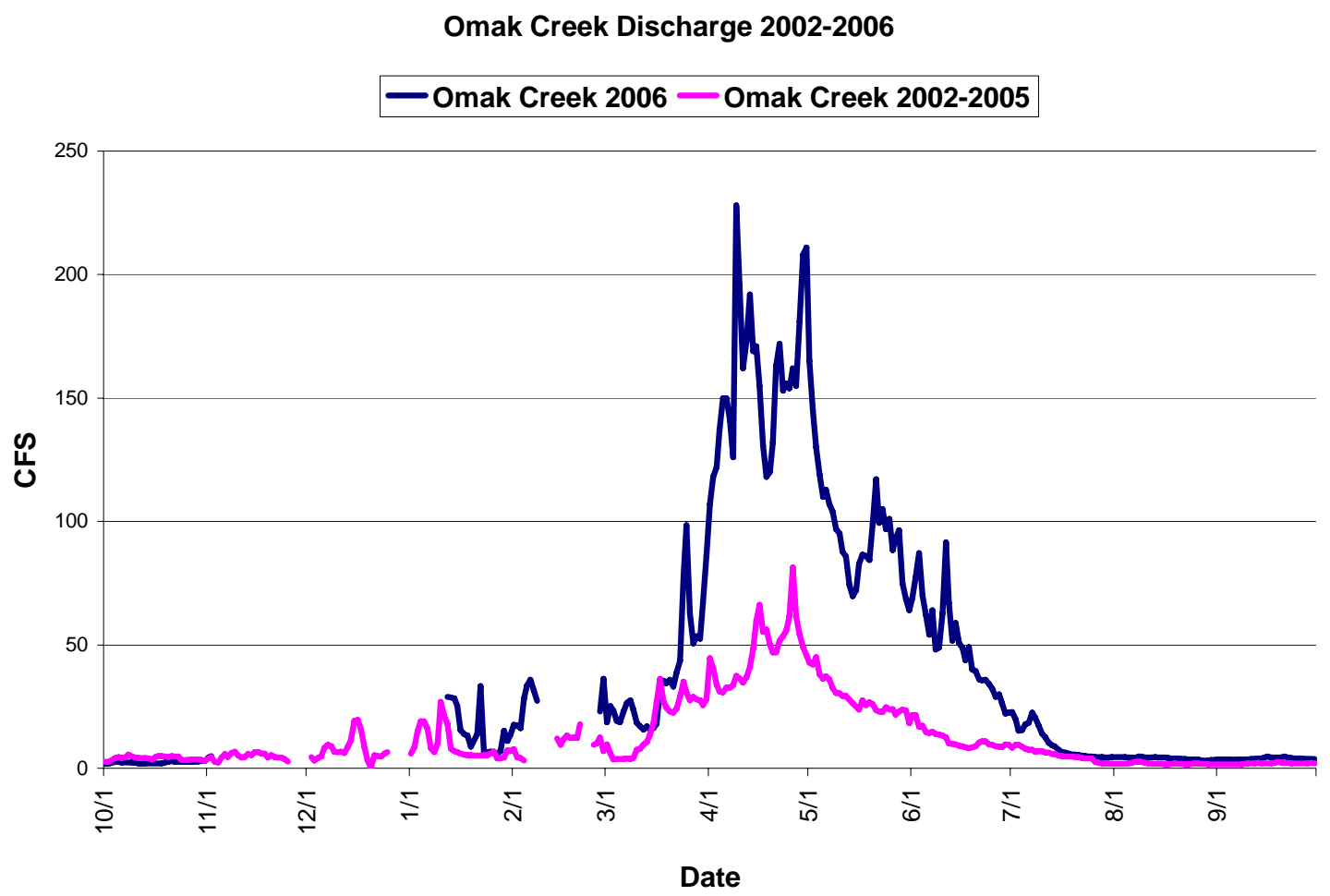

Figure 6: Omak Creek mean daily discharge hydrograph comparing data collected in 2006 with mean discharge from 2002-2005.

\section{Tunk Creek}


Discharge data has been collected for Tunk Creek since 2003 at a real-time telemetry gauging station owned and operated by WDOE that is located a short distance above Tunk Falls https://fortress.wa.gov/ecy/wrx/wrx/flows/station.asp?sta=49E080. From these data it could be presumed that Tunk Creek is perennial but based on field observations of the lower reach (below Tunk Falls) it would more properly be defined as intermittent. Since 2005, OBMEP has attempted to conduct annual snorkel surveys but on August $30^{\text {th }}$ of 2005 and again on August $28^{\text {th }}$ of 2006 no water was present at the mouth of Tunk Creek so no snorkel surveys were possible (Kistler et al. 2006, Kistler and Arterburn 2007). Upon review of discharge data collected upstream it has been determined that any flows below 0.2-CFS at the WDOE gauge results in a dry stream bed below Tunk Falls. These conditions typically occur from mid-July through the first week in September. The lack of persistent overland flows downstream of Tunk Falls greatly reduces the likelihood that summer steelhead production in Tunk Creek will add to overall smolt production for the Okanogan River population.

The typical hydrograph peaks in April with low flows in August (Figure 7). In 2006, a record peak mean daily discharge was measured on 4/12/2006 at 54.8-CFS with an instantaneous peak of 83.8-CFS. The previous record discharge was measured on $4 / 25 / 2003$ at 38.3-CFS with an instantaneous peak of 45.5-CFS. The lowest discharges measured in 2006 were 0.2 -CFS and this occurred on several dates from 8/7/2006 through 9/10/2006. These minimum discharge readings have been correlated with zero discharge at the mouth of Tunk Creek. Although, discharge data show sufficient water was available for good access to spawning habitats for adult steelhead, discharge during the fall was reduced to the point that no production was likely to occur from any redds that were created.

Tunk Creek Discharge 2002-2006

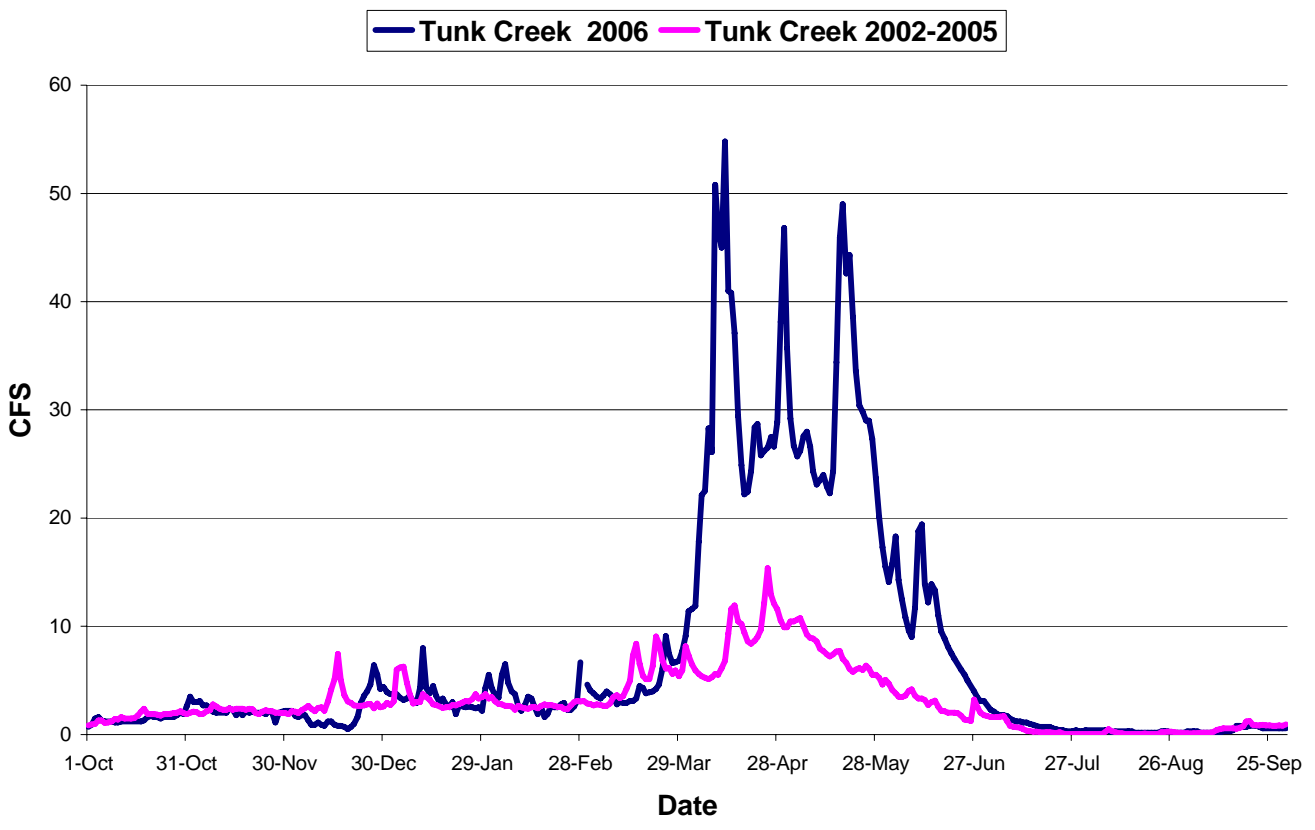

Figure 7: Tunk Creek mean daily discharge hydrograph comparing data collected in 2006 with mean data from 2002-2005. 


\section{Bonaparte Creek}

Discharge data collected for Bonaparte Creek is monitored by WDOE at a real-time telemetry gauging station located at the Highway 97 Bridge in the town of Tonasket, Washington. Discharge and temperature data have been recorded consistently since 2003. The hydrograph of discharge in Bonaparte Creek typically shows a high flow during the period from March through June with low flows typically occurring in the period from July through October and base flows in August. Winter rain typically increase flows to an intermediate level during the period from November through February (Figure 8). Low flows were relatively consistent in 2006 compared to average flow data from 2002 to 2006. In 2006, a record peak mean daily discharge was measured on 5/27/2006 at 38CFS. The lowest discharge measured in 2006 was 0.3 -CFS on $08 / 25 / 2006$ which was thirty times above the minimum discharge record in 2003 to 2005 of 0.01 CFS. Data from 2006 shows a greater peak discharge and a steeper ascending limb than the average of previous years (Figure 8). Missing values for 2003-2005 represent isolated days when no data was being collected due to ice or other equipment malfunctions.

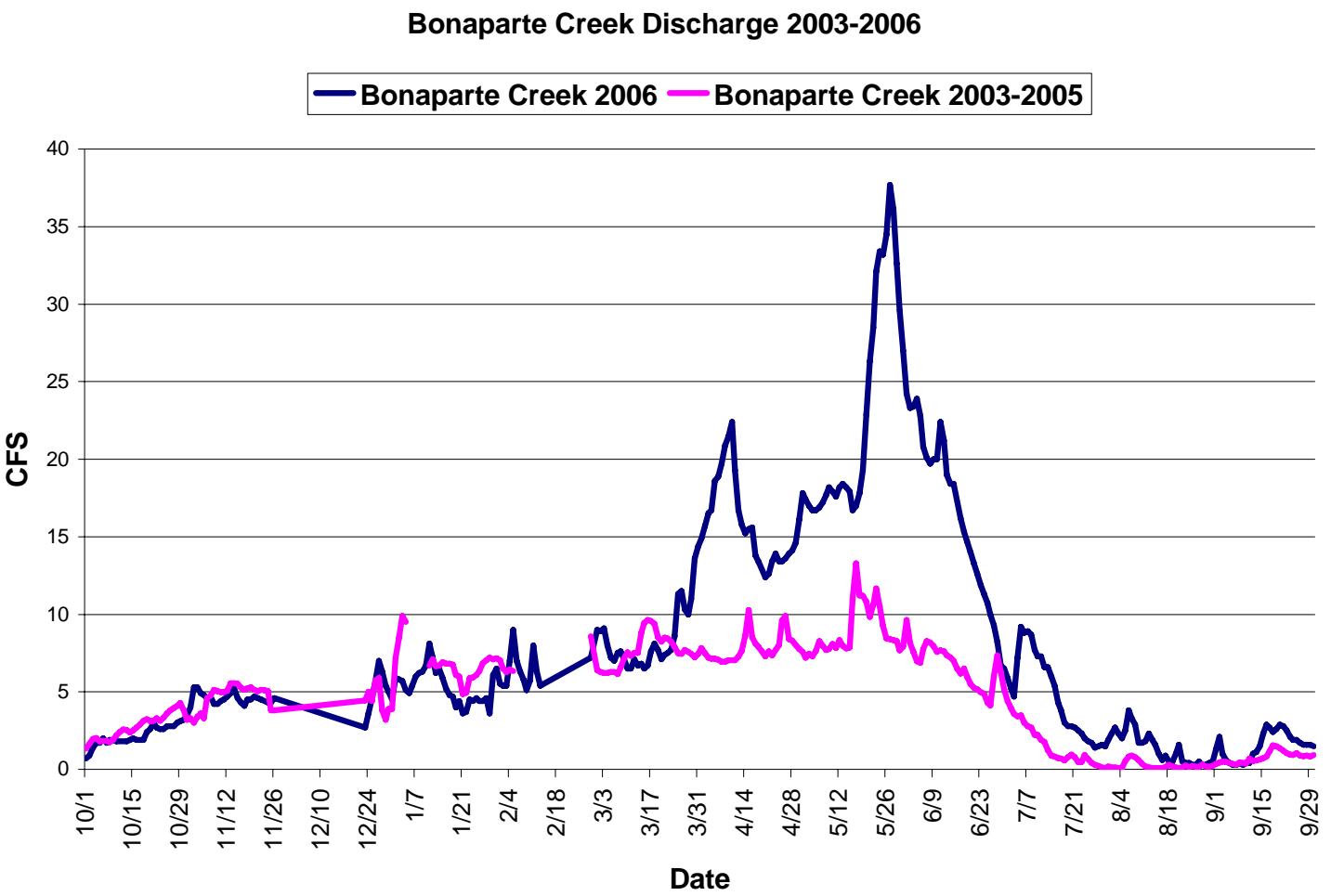

Figure 8: Discharge for Bonaparte Creek in 2006 compared to the average flow from 2003-2005.

\section{$\underline{\text { Tributaries in Canada }}$}

Flow data in Canada on tributary streams near the mouth have been collected by the Colville Confederated Tribes OBMEP program through a contract with Environment 
Canada. Data has been collected at Vaseux, Inkaneep, and Shuttleworth creeks since March of 2006.

Vaseux Creek had a very steep ascending limb and a prolonged high flow period from April 26th to June $16^{\text {th }}$. The highest mean daily discharge was 556 CFS on 5/20/2006 and the low mean daily discharge was zero from $7 / 28 / 06$ to $11 / 29 / 06$. This is a snow pack driven watershed as it drains Mount Baldy. This stream is perennial in most portions of the watershed and there is a lot of potential here for salmon and steelhead spawning and rearing. However, the lower portion of the creek has gone dry in recent years (Figure 9) likely resulting in minimal production.

Inkaneep Creek is a perennial stream that drains the west side of Mount Baldy emptying into the northern basin of Osoyoos Lake. Anadromous fish are able to access 2.4 river miles of the creek from the confluence with the lake. In 2006, there was a steep ascending limb to reach peak discharge. Mean daily peak flow of 157 CFS, occurred on $5 / 21 / 06$. The low flow value was, 0.9 CFS and occurred on $8 / 29 / 06$. Oncorhynchus Mykiss have been live trapped in the creek (Long 2006). At the present time this creek supports the majority of summer steelhead spawning and smolt production in Canada (Kistler 2006, Arterburn 2006, 2007).

Shuttleworth Creek currently is outside the range of anadromous fish due to McIntyre Dam which is located south of Okanogan Falls, BC. This creek appears to be perennial and has the potential for steelhead spawning and rearing once passage at McIntyre Dam is achieved. The mean daily peak flow of 95 CFS occurred on 5/20/06 and the lowest value recorded in 2006 was 0.03 CFS from $7 / 25 / 06$ to $9 / 11 / 06$. The impacts to coldwater salmonids in this stream from extremely low discharge such as occurred during 2006 are not well understood. Little is currently known about the mechanisms that control, regulate, or impact discharge in Shuttleworth Creek.

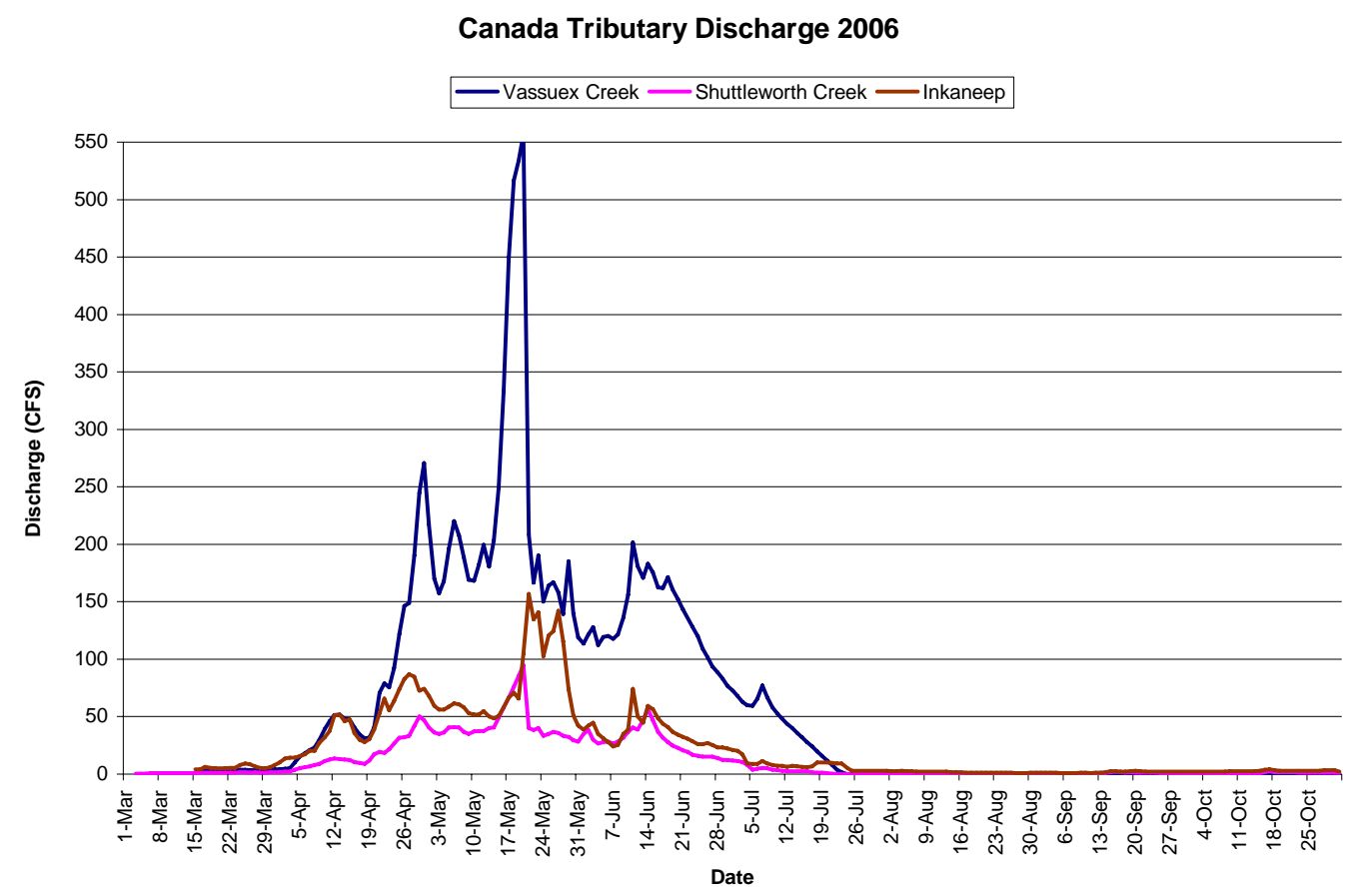

Figure 9: Real-time discharge for Environment Canada gauge on Vaseux, Inkaneep and Shuttleworth Creeks in 2006. 


\section{Discharge-Mainstem Rivers}

Most mainstem flow monitoring is conducted by the United States Geological Survey (USGS) with the exception of one site on the Similkameen River operated by WDOE and one site near the town of Oliver in Canada operated by Environment Canada. All the United States gauging stations provide real-time discharge data but the site in Canada is only a near real-time station and complete yearly data are not posted until results are one year old.

The Okanagan River as it flows out of Canada is regulated at dams located at outlets of Okanagan, Skaha, Vassuex, and Osoyoos lakes. Because discharge from these lakes is highly managed for; flood control, to maintain lake elevation, irrigation, and to enhance fish production the hydrograph is muted with lower peak flows, higher low flows and higher inter-daily variability than would be expected from the historically unregulated system (Figures 10\&11). Flows typically peak in late May to early June with low flows in October to January. The remainder of the year is contained in the ascending limb (February to May) or descending limb (July to October) of the hydrograph (Figure 10).

Once in the United States the Similkameen River dominates the hydrograph of the Okanogan River. During peak flows the Similkameen River contributes about 6.5 times more water than the Okanogan carries coming out of Canada. However, during the heat of summer (July through September) and base flow periods (October through January) each river contributes approximately equal amounts of water to the confluence. Peak discharge typically occurs in late may to early June with an ascending limb that occurs from mid-march through early may and a descending limb that exists from July through September.

\section{$\underline{\text { Okanogan River at Oliver, BC }}$}

In 2006, an abundance of snow produced a peak discharge of 2758 CFS on 06/11/2006 (Figure 10). However, flow management resulted in discharges that were considerably below the historic averages during the periods from November through January, late March to early May, and late July through early September. Due to the low flow periods the total amount of water produced from the Okanogan River basin was only slightly above average. Because these flows are managed for the benefit of sockeye salmon using a Fish \&Water Management Tool (http://www.essa.com/projects/descriptions/1250.htm) it is likely that these flows are highly productive for this species and other fall spawners. However, the full impacts resulting from these managed flows on spring spawning salmon and steelhead remain unknown. In 2006, steelhead spawning likely occurred during flows that were less than historic flows. Peak runoff however, was closely aligned with the emergence timing for Okanogan River summer steelhead whereas historic data align summer steelhead emergence with the descending limb of the hydrograph. 


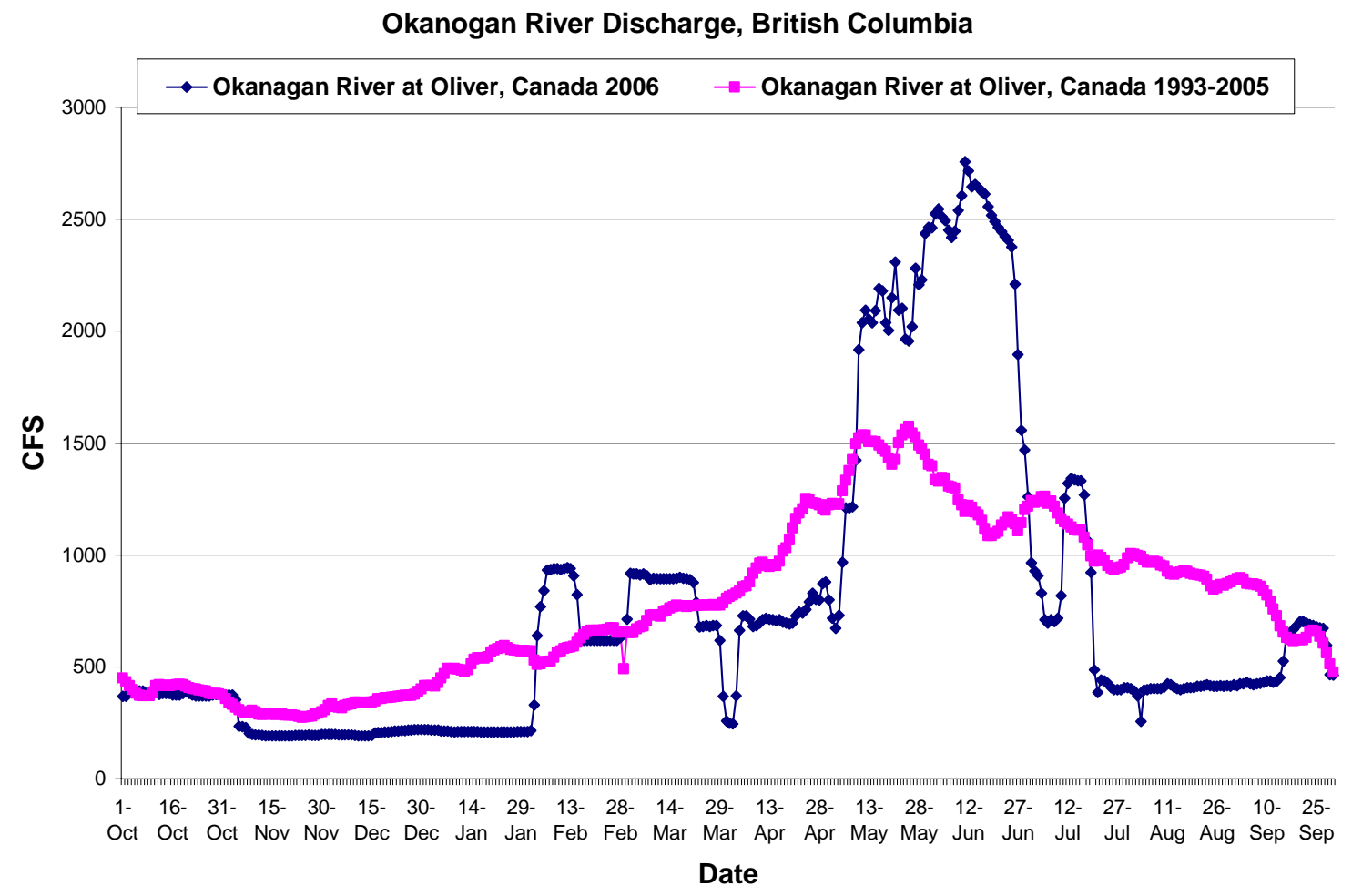

Figure 10: Real-time discharge from gauge on the Okanogan River located at the town of Oliver in Canada showing the historic average from 1993 to 2005 compared to 2006.

\section{Okanogan River at Oroville, WA}

In 2006, peak flows were 2,640 CFS on June $17^{\text {th }}$, compared to the average peak flow in May of 1,500 CFS (Figure 11). Multiple flow manipulations upstream resulted in discharges that were considerably below the historic averages during the periods from late November through early February, and from Late July through September. Discharge was highly volatile from February through May. The total amount of water produced from the Okanogan River basin was only slightly above average. However, discharges below Zosel Dam are highly regulated by the rules set forth by the International Joint Commission and flows released by Canadian water managers who have agreed to use the FWMT. These rules result in major operational constraints that can result in discharge patterns that are not beneficial to salmonid using habitats downstream. For example, extremely low discharges during early April have negative impacts on spawning summer steelhead by encouraging them to spawn in areas that will become scour zones during high flows, resulting in high egg to fry mortalities. Approaches to reduce these impacts and increase operational flexibility to meet multiple uses for water from Osoyoos Lake are currently being considered by WDOE who owns Zosel Dam. 


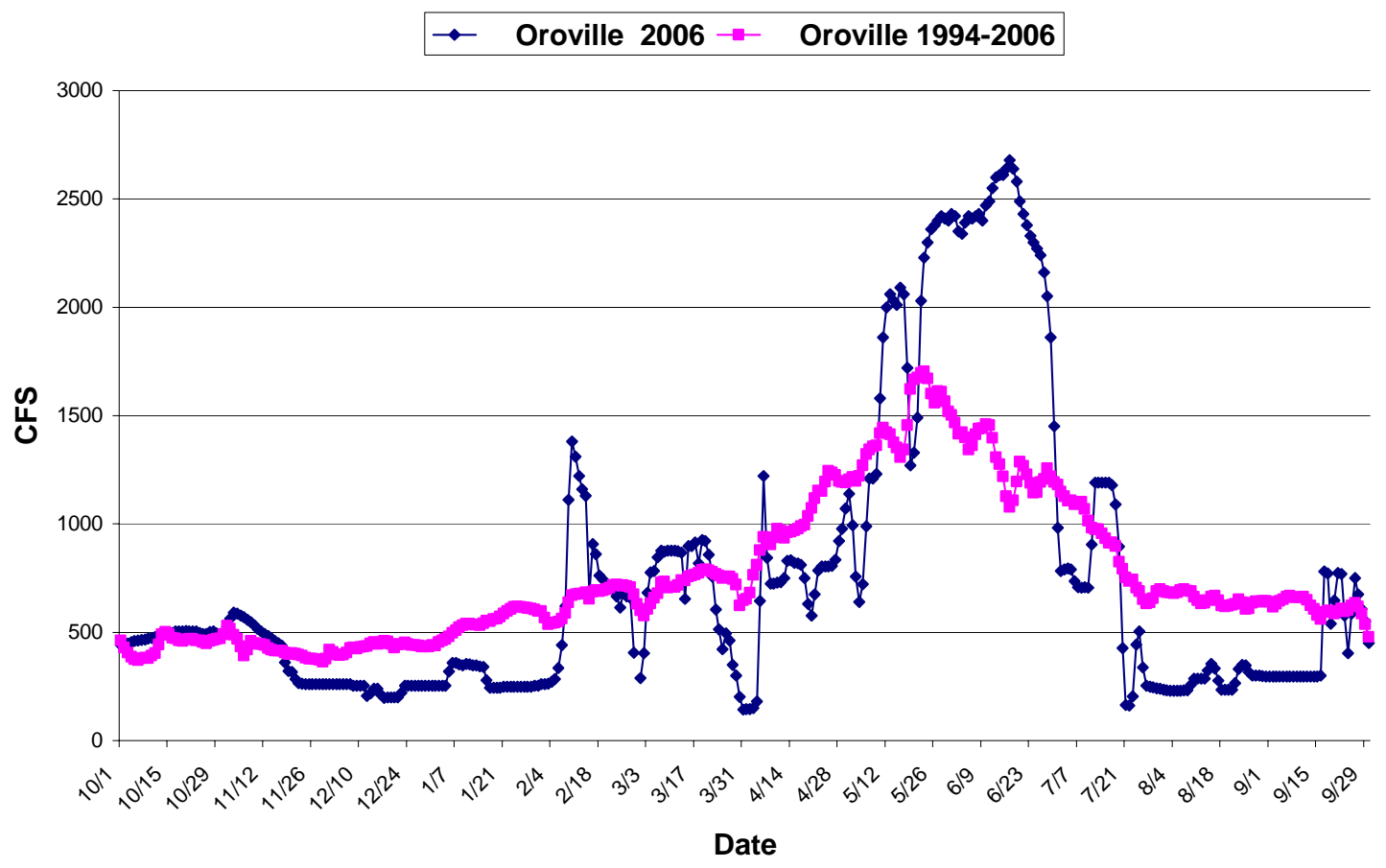

Figure 11: Real-time discharge for USGS gauge on Okanogan River located at the Highway 97 Bridge at the town of Oroville in 2006 compared to the historic average from 1993 to 2005 . Flows are highly regulated resulting in an irregular hydrograph.

\section{$\underline{\text { Similkameen River at Oroville, WA }}$}

The hydrograph for the Similkameen River shows a high flow period from May through mid-June and a low flow period that lasts from August to March (Figure 12) . Most of the flow in this drainage is generated directly from snowmelt. In 2006 , daily average peak flow data was 19,500 CFS on the $22^{\text {nd }}$ of May, compared to the average daily peak flow from 2002-2005 of 9,885 CFS on the $12^{\text {th }}$ of June. Run-off was delayed by 2 weeks in 2006 compared to the historical averages and peaked rapidly in May. However, the low flow period from October to March and from July through September approximated the historical averages. For example, extremely low discharges during early April could have encouraged spawning summer steelhead to build redds in areas that will become scour zones during high flows, potentially resulting in higher than normal egg to fry mortalities.

Okanogan River below the Confluence with the Similkameen River

The mainstem Okanogan River downstream of the confluence with the Similkameen River is monitored by the USGS at two sites; one near the town of Tonasket (Figure 13) and one near the town of Malott, Washington (Figure 14). Peak flows in 2006 were approximately 6,000 CFS higher than the twelve year average. Peak flows were 16,700 CFS at Tonasket and 17,600 CFS at Malott on May 21st. Twelve year, average daily peak flows were on May $31^{\text {st }}$ and only reached 10,855 CFS at Tonasket and 11,180 CFS at Malott. Peak flows in 2006 were ten days earlier in May then average peak flows at 
both gauges. Base flow conditions from October to mid-March and again in September approximated normal compared to the historic averages.

The 2006 water year had an abundance of water due to above average snow packs in the mountains but run-off proceeded rapidly resulting in a tall but narrow hydrograph. The extreme discharges recorded in 2006 are likely to have benefited the spawning reaches along the main-stem Okanogan River by disturbing gravels and flushing fine sediments from areas that would be used for spawning in normal water years. Although eggs in the gravels may have experience scouring in 2006 this disturbance will likely benefit mainstem salmonid production for the next several years to come. Missing data was due to malfunctions caused by ice.

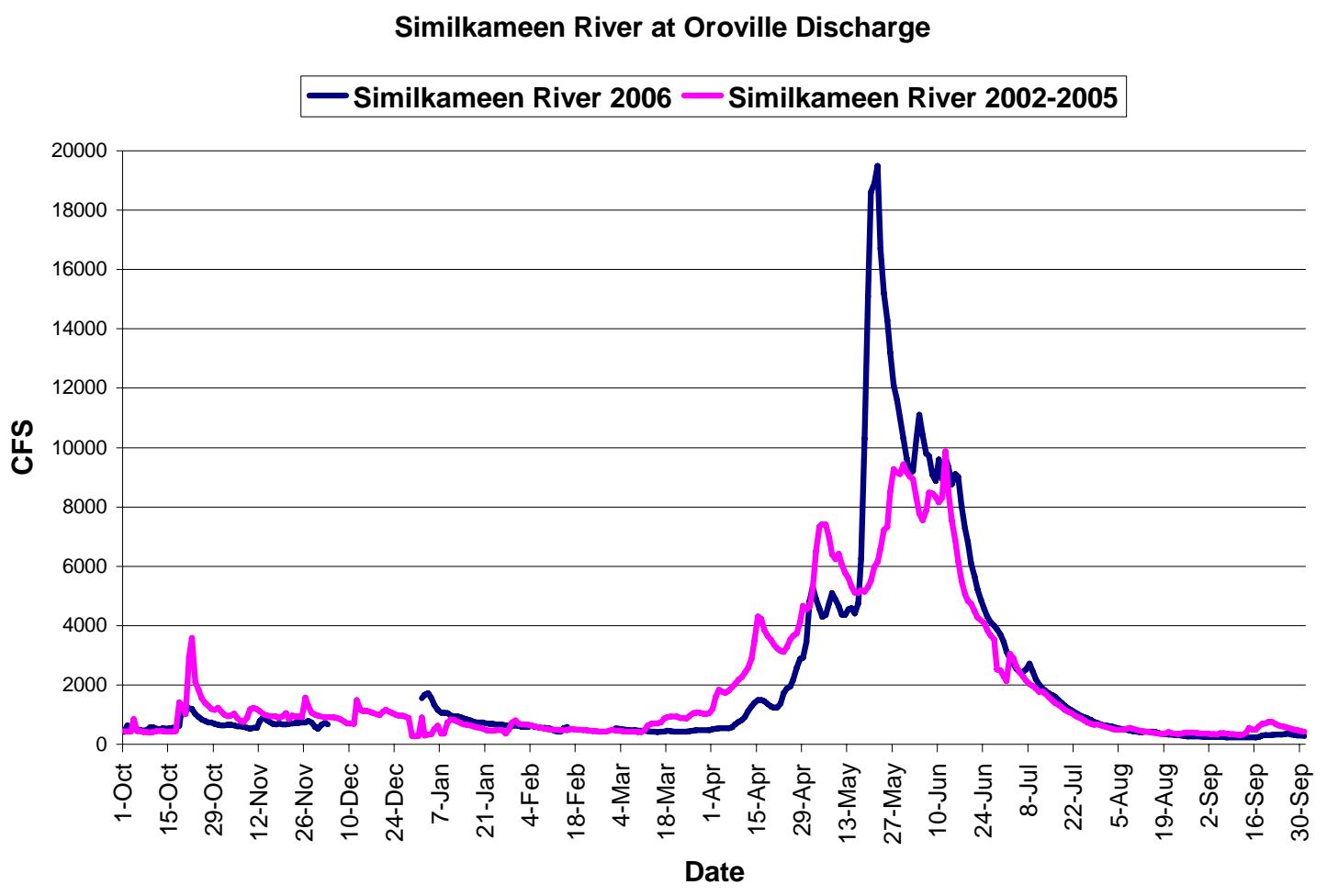

Figure 12: Real-time discharge for WDOE gauge on Similkameen River located at the town of Oroville comparing the historic daily average from 2002 to 2005 to 2006 .

\section{Twelve Year Discharge trends on the Okanogan and Similkameen Rivers}

We graphed 12 year discharge trends for the Okanogan River subbasin at; Oliver, British Columbia, Oroville and Malott, Washington, and on the Similkameen River at Nighthawk, Washington. We compared the minimum mean daily discharge value across the 12 year period from 1995-2006. We selected the minimum mean daily value because it ultimately influences the maximum amount of rearing or spawning habitat that would be available to salmonids within a given year reflecting the maximum carrying capacity.

Our results indicate that in general, the discharge trend supports that headwater areas remain little impacted by changes to minimum instream flows with the impact becoming more defined as you move down stream through the watershed. All sites graphed had 
what appeared to be a slightly decreasing trend. However, based upon our statistical analysis we discovered that the Similkameen River as it flows into Washington State did not have a discernible trend and should therefore be considered stable in regard to minimum annual discharge. On the Okanogan River minimum flows have decreased over the last 12 years and the rate of change was estimated at $-2.1 \mathrm{CFS} / \mathrm{yr}$ at Oliver, $-7.4 \mathrm{CFS} / \mathrm{yr}$ at Oroville, and -28.3CFS/year at Malott (Figure 15). This trend is not beneficial for salmonid production and efforts to reverse this trend should be strongly encouraged.

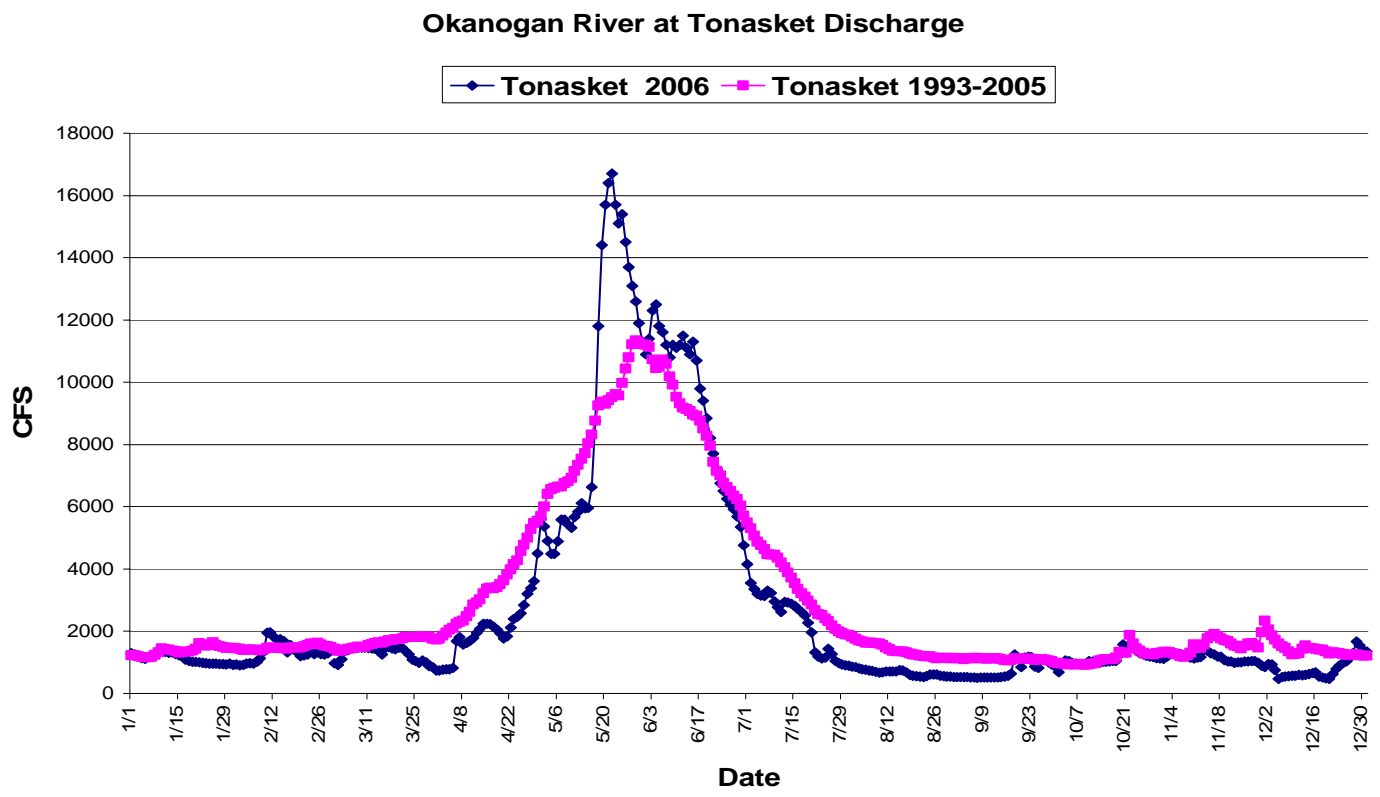

Figure 13. Real-time discharge form the USGS gauge on the Okanogan River located near the town of Tonasket, WA comparing 2006 to the historic daily average from 1993 to 2005.

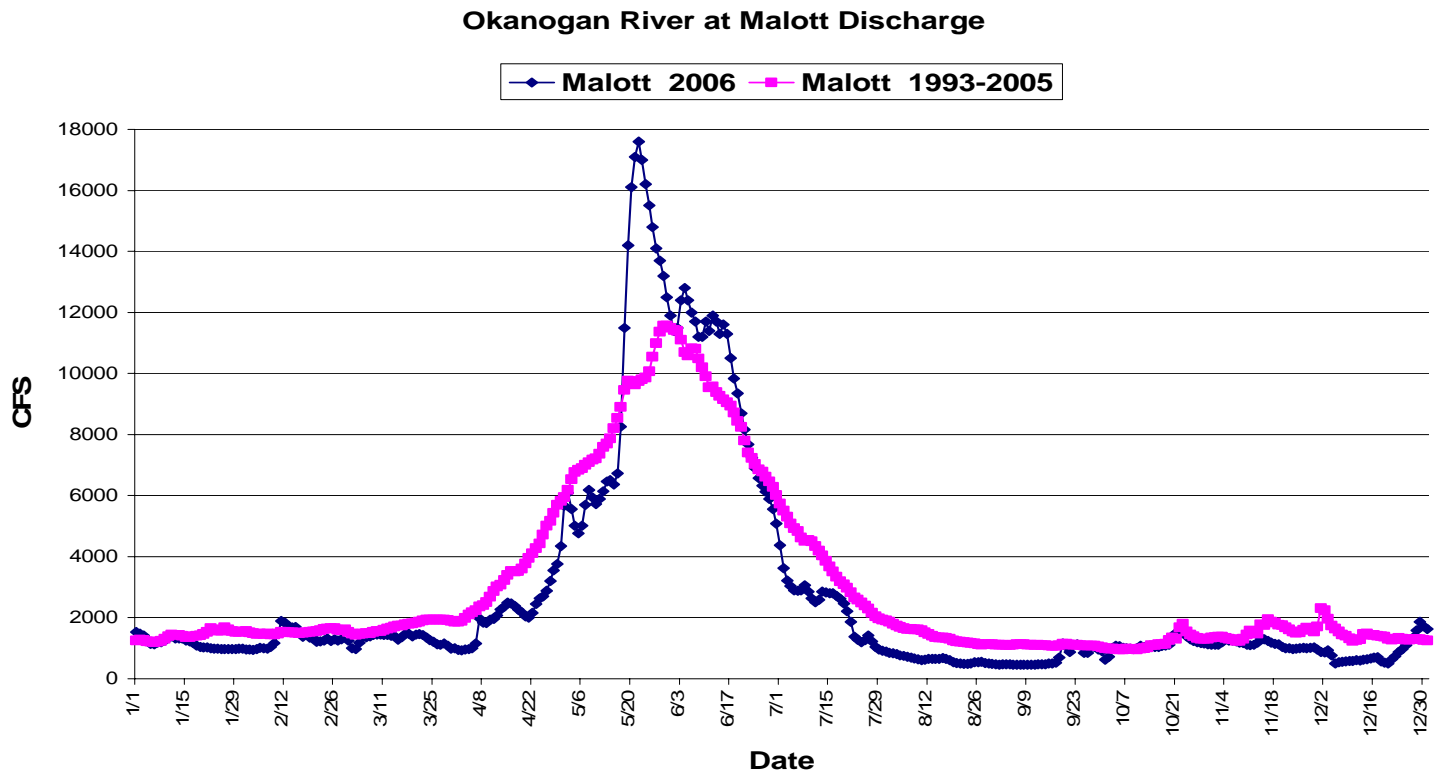

Figure 14. Real-time discharge for WDOE gauge on the Okanogan River located near the town of Malott comparing the historic daily average from 1993 to 2005 compared to 2006 data. 


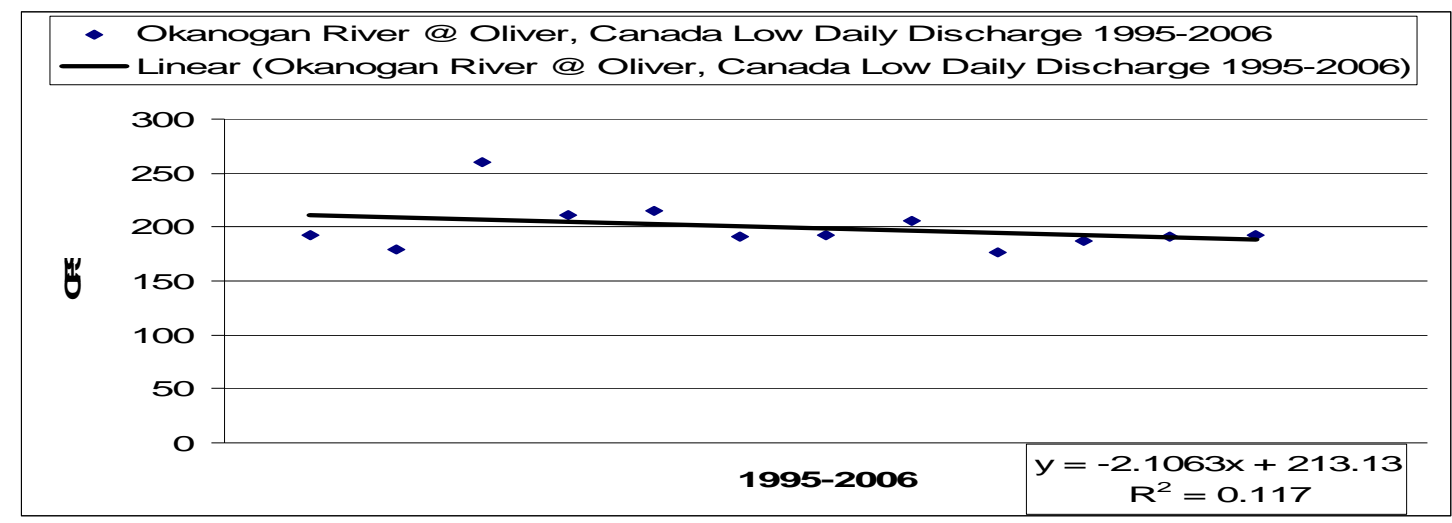

- Okanogan River @ Oroville, Washington Low Daily Discharge 1995-2006 Linear (Okanogan River@ Oroville, Washington Low Daily Discharge 19952006)
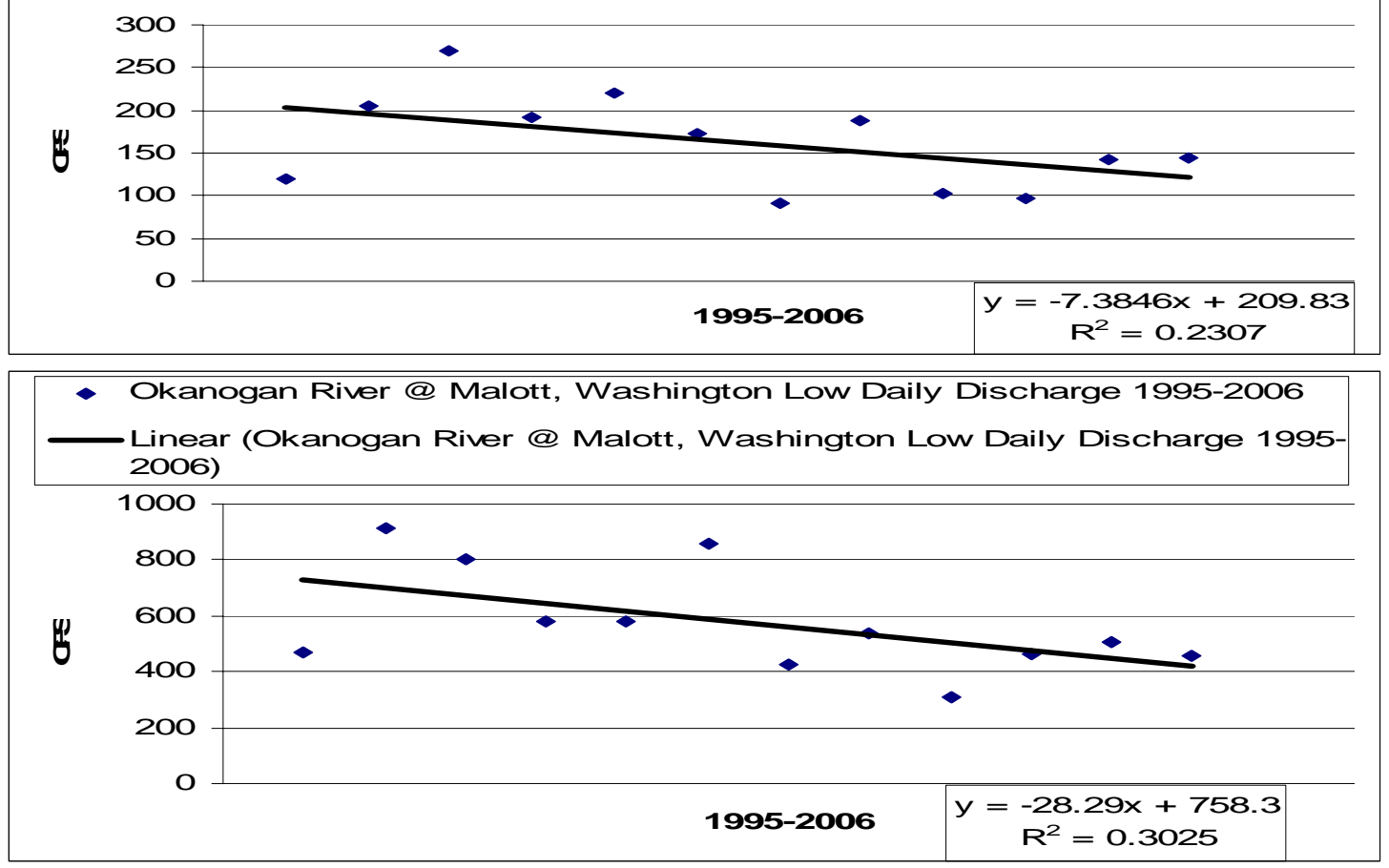

- Similkameen River @ Nighthawk, Washington Low Daily Discharge 1995-2006

- Linear (Similkameen River @ Nighthawk, Washington Low Daily Discharge 1995-2006)

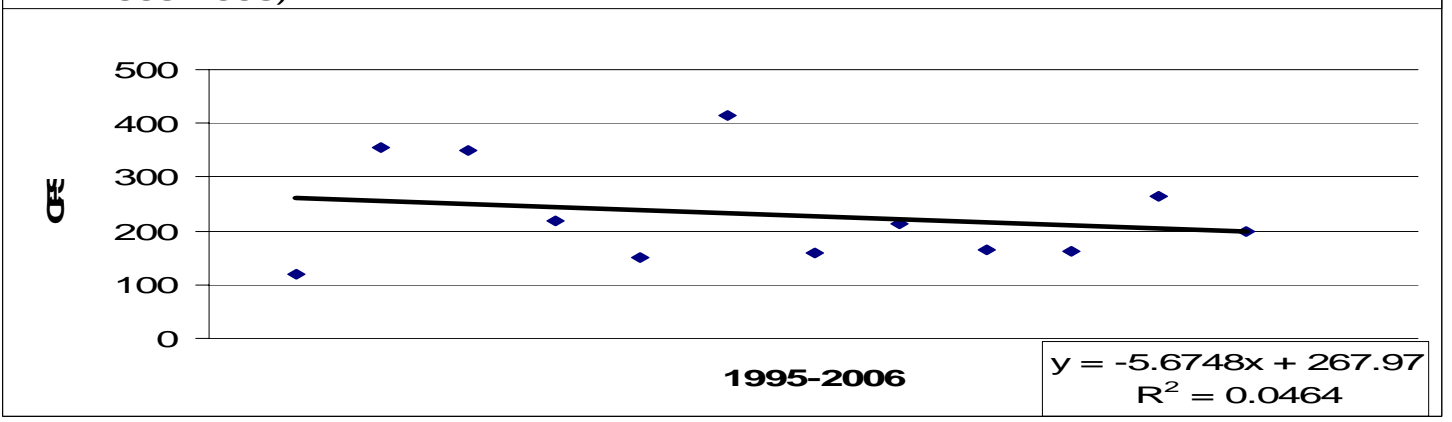

Figure 15. Minimum, mean daily discharge trend over a 12 year period from 1995-2006 taken from realtime gauging stations located along the Okanogan and Similkameen rivers 
These results indicate that consumptive uses of water are magnified as you progress downstream resulting in less water remaining instream during low discharge periods. Although changes in headwater areas appear small by comparison to the cumulative impacts of many headwater areas that help contribute to large downstream changes. Many of the impacts to headwater streams occurred many years ago (i.e. diversions, etc.) thus, little water remains during the low flow periods. Small headwater changes as measured on the mainstem Okanogan and Similkameen Rivers could mask major changes within certain sub watersheds. Future discharge monitoring should attempt to expand real or near real-time gauging sites to additional tributary watersheds in the future and then use these data to analyze changes over time.

\section{Water Quality indicators other than discharge and temperature}

Water Quality information other than discharge and temperature were collected as part of OBMEP at all EMAP sites located on tributary streams of the Okanogan River (Figure 1 \& 2). During the 2007-2009 Northwest Power and Conservation Councils, Fish and Wildlife Program funding allocations, insufficient funds were awarded for continued water quality data collection under the OBMEP project. Therefore, these data were only collected from May of 2005 through February of 2007. This decision has greatly reduced or at least delayed the twenty year experimental OBMEP design for water quality data in the tributaries. Regardless, information is collected by WDOE at fixed sites located at the Okanogan River in Oroville (upper Okanogan River), Malott (lower Okanogan River) and on the Similkameen River at Oroville. The WDOE sites collect additional data such as nutrient parameters which were always considered beyond the OBMEP scope due to fiscal limitations.

For this report we have compared and analyzed the following water quality indicators for each WDOE monitoring site: dissolved oxygen, turbidity, $\mathrm{pH}$, ammonia, nitrogen phosphorous and conductivity. When and where possible we compared twelve year status averages from 1993-2005 with status data collected in 2006 and developed trends for the period from 1994-2006. Because no historical data exists for the OBMEP tributary sites only between site status comparisons based on 2006 data were possible. The biological linkages for each water quality parameter on anadromous fish found within the Okanogan River basin are provided as part of each indicators description. Water quality information is presented for each indicator and presented in graphic form below (Figures16-35).

\section{Dissolved Oxygen}

Oxygen is critical for fish and when oxygen levels drop below $6 \mathrm{mg} / \mathrm{L}$ adult salmonids can become stressed, this is rarely the case in fluvial environments (Davis 1975). Research has determined that a correlation between the rate of development and survival of salmonid eggs with dissolved oxygen levels exists as they begin to hatch (Piper et al. 1982). If dissolved oxygen levels are below $8 \mathrm{mg} / \mathrm{L}$ survival and development at time of hatching reduces rapidly. At levels above $8 \mathrm{mg} / \mathrm{L}$ salmonid survival and development benefits increase at a slower rate until $10 \mathrm{mg} / \mathrm{L}$. The amount of oxygen that can be dissolved in water is a function of temperature and pressure. To reduce solubility below 
$6 \mathrm{mg} / \mathrm{L}$ requires temperatures greater than $25^{\circ} \mathrm{C}$ and atmospheric pressures below $560 \mathrm{~mm}$ $\mathrm{Hg}$ (Colt and Tomasso 2001). For fluvial systems these impacts are isolated due to air to surface water exchange processes that are enhanced through the turbulence of moving waters. In the Pacific Northwest dissolved oxygen readings below $8 \mathrm{mg} / \mathrm{L}$ are isolated to lentic environments, areas with high biological oxygen demands (i.e sewage returns), or during times when streams become dewatered.

The average barometric pressure in the Okanogan valley is $760 \mathrm{~mm} \mathrm{Hg}$ and water temperatures rarely exceed $25^{\circ} \mathrm{C}$ therefore the theoretical minimum dissolved oxygen would be approximately $8 \mathrm{mg} / \mathrm{L}$ (http://www.weatherunderground.com ). Most experts believe that at $8 \mathrm{mg} / \mathrm{L}$ or more dissolved oxygen is considered to be excellent for salmonids and that levels above $6 \mathrm{mg} / \mathrm{L}$ are adequate provided no eggs are actively hatching. Although it is unlikely that barometric pressures will likely change in the foreseeable future global warming issues could result in increased water temperatures in the near term that could result in reduced dissolved oxygen levels.

\section{$\underline{\text { Dissolved Oxygen-Main-stem Status and Trend }}$}

Empirical data collected from 1993 to 2005 supports the scientific literature findings that show a close correlation between temperature and dissolved oxygen. In the Okanogan River subbasin this mean high levels of dissolved oxygen (12-14 mg/l) present from December through March during the cold water months and low levels of dissolved oxygen occurring from mid-July through September during the warm water months. In 2006, dissolved oxygen levels on the lower Okanogan River stayed just above $8 \mathrm{mg} / \mathrm{L}$, with the lowest reading of $8.2 \mathrm{mg} / \mathrm{L}$ occurring on September 14, 2006 (Figure 16). Dissolved oxygen levels in the Similkameen River stayed above $8 \mathrm{mg} / \mathrm{L}$ for all of 2006, with the lowest reading of $8.78 \mathrm{mg} / \mathrm{L}$ on September 14, 2006 (Figure 17). Egg incubation and hatching occurs for summer/fall Chinook from October through January and for summer steelhead late-March through early-July. Dissolved oxygen readings typically exceed $10 \mathrm{mg} / \mathrm{l}$ during this timeframe and therefore this indicator is unlikely to adversely impact these fish species. Dissolved oxygen readings in early October for summer/fall Chinook and from June through early July for summer steelhead can occasionally drop to the range from 8 to $10 \mathrm{mg} / \mathrm{L}$ and therefore warrants continued monitoring. Especially near Oroville which is near primary spawning areas to ensure that readings do not drop below $8 \mathrm{mg} / \mathrm{l}$ in the future.

We studied 12 year trends for mean dissolved oxygen levels in the Okanogan and Similkameen Rivers for the period from 1995 to 2006. We focused our trend analysis on the time of egg incubation for summer/fall Chinook (October thru January, Figure 18) and summer steelhead (late-March through early-July, Figure 19). We found that for the past 12 years dissolved oxygen levels have been on a slightly downward trend during summer/fall Chinook egg incubation. Reductions in the mean dissolved oxygen levels are occurring at a rate from -0.054 to $-0.086 \mathrm{mg} / \mathrm{L} / \mathrm{yr}$ at the Similkameen River and Okanogan River at Oroville sites respectively (Figure 18). Trends for the summer steelhead incubation period were less defined. Statistics indicated that dissolved oxygen levels at the Similkameen River and Okanogan River at Malott remained stable. A slightly downward trend was marginally detectable for the site on the Okanogan River at Oroville with dissolved oxygen levels declining at a rate of $-0.033 \mathrm{mg} / \mathrm{l} / \mathrm{yr}$ (Figure 19). 
The cause for these declining trends in dissolved oxygen levels is likely related to increasing water temperatures but the extent that other factors could be influencing these results remains unknown. Although this trend is moving in a direction that is of concern, dissolved oxygen levels are high enough, at present, that they are unlikely to have a negative impact on salmonids.

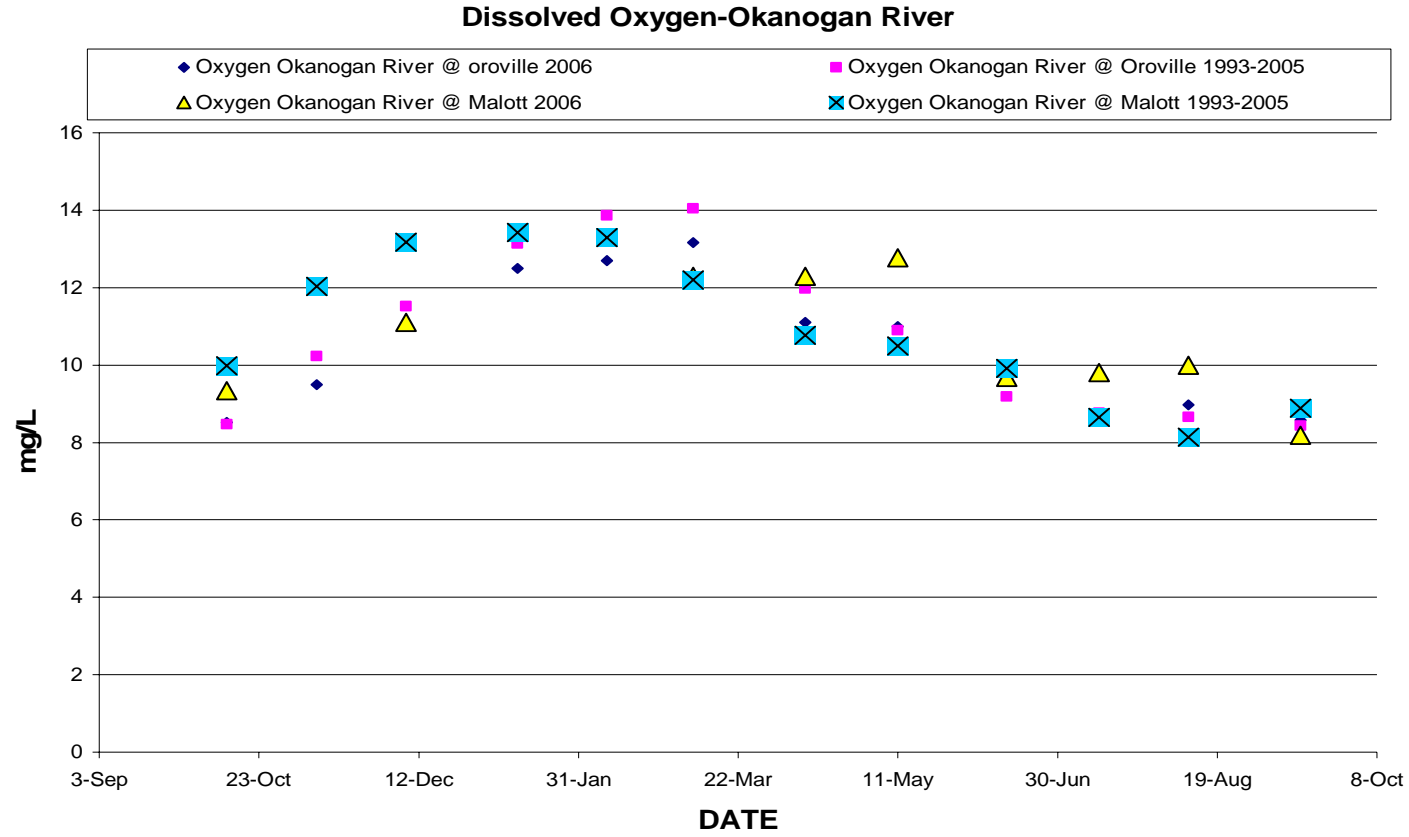

Figure 16. Status data for dissolved oxygen levels collected by WDOE for the Okanogan River sites located near the town of Malott, and Oroville, Washington comparing the historic average from 1993 to 2005 compared to 2006 data.

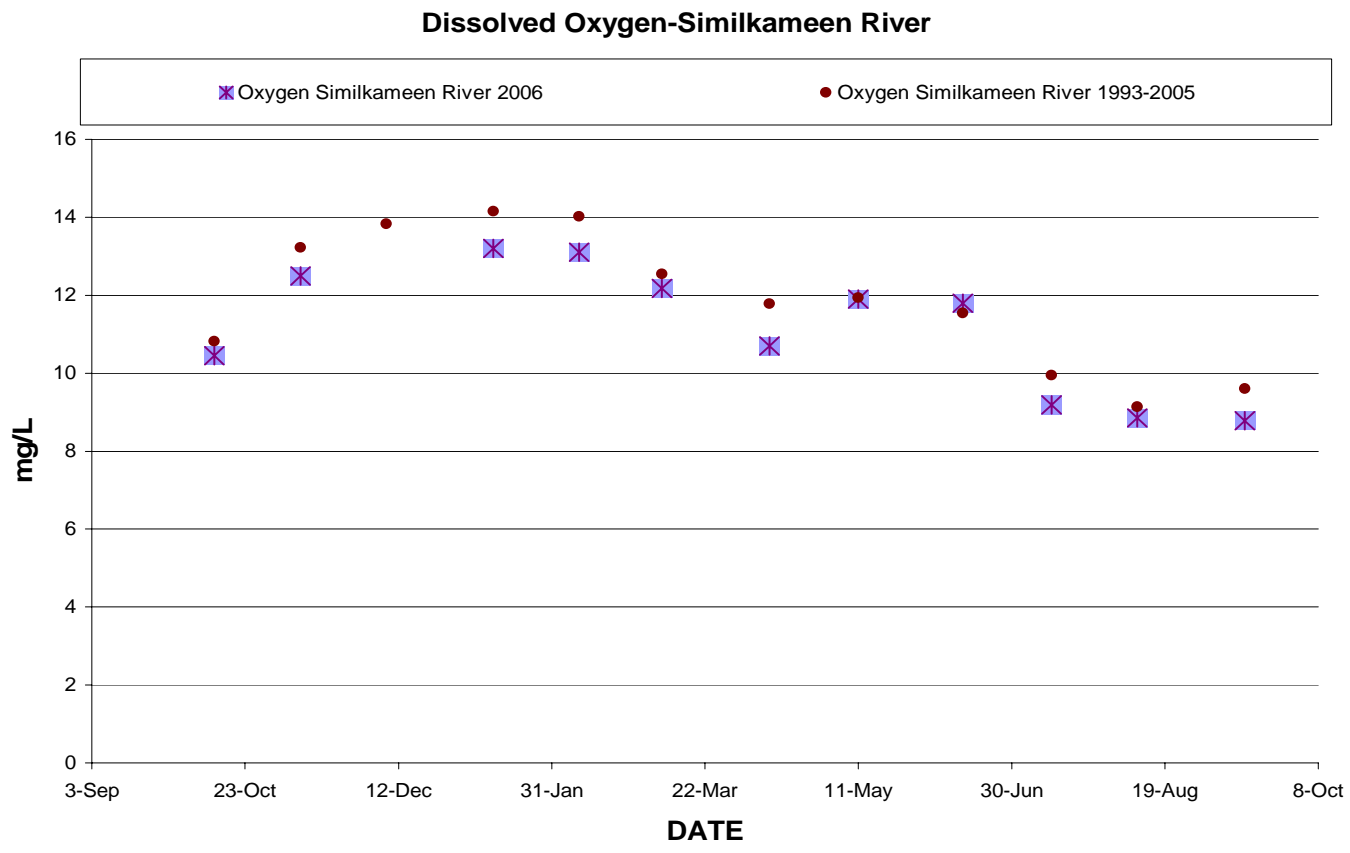

Figure 17. Status data for dissolved oxygen levels collected by WDOE for the Similkameen River sites located near the town Oroville, Washington comparing the historic average from 1993 to 2005 compared to 2006 data. 
Dissolved Oxygen 12 year Trend During Summer/Fall Chinook Egg Incubation in the Okanogan and Similkameen Rivers
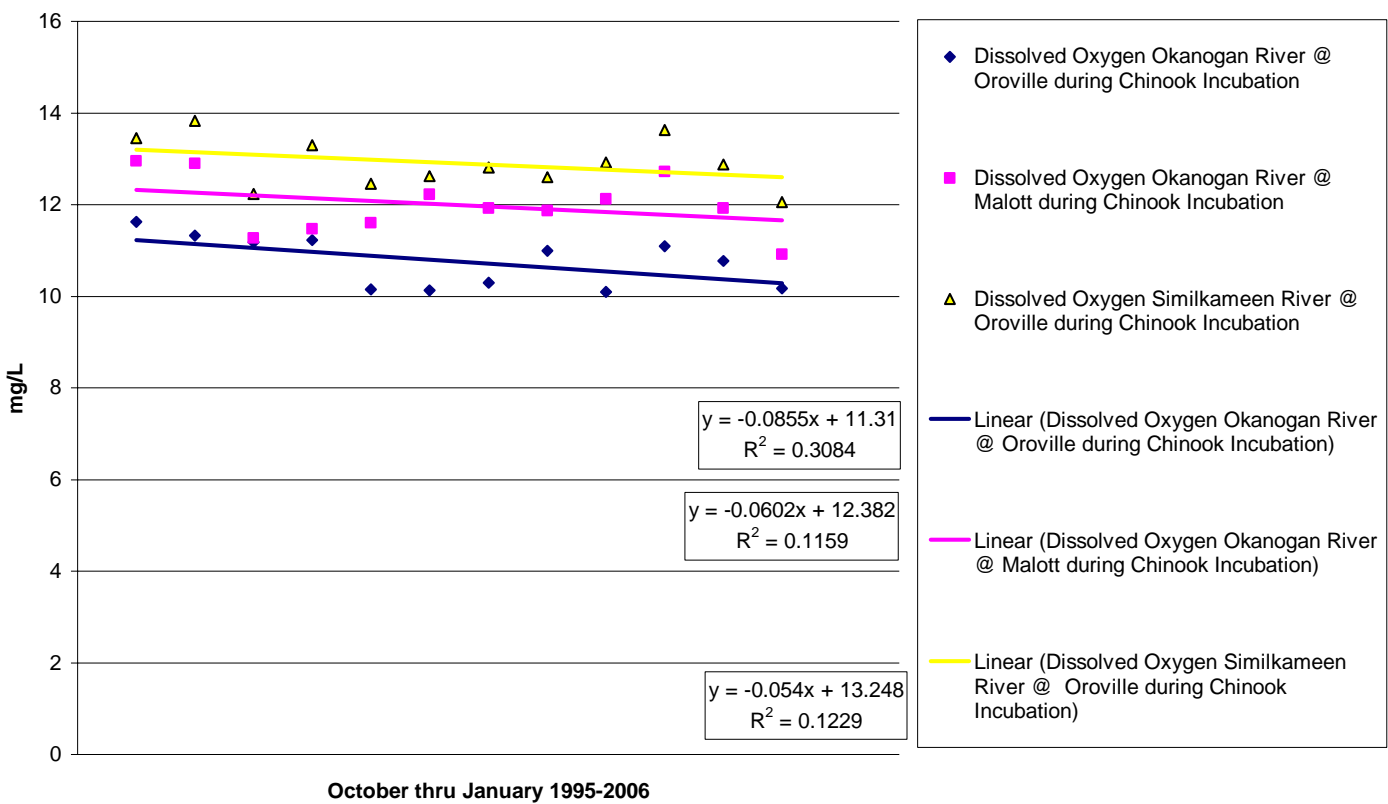

Figure 18. Mean annual dissolved oxygen levels recorded for the period from October through January (when summer/fall Chinook eggs are incubating) from 1995 to 2006. Dissolved oxygen levels represent the mean values that were derived using WDOE grab sample data for the Okanogan River and Similkameen River sites located near the town of Malott, and Oroville, Washington.

\section{Dissolved Oxygen 12 Year Trend During Steelhead Egg Incubation in the Okanogan and Similkameen Rivers}
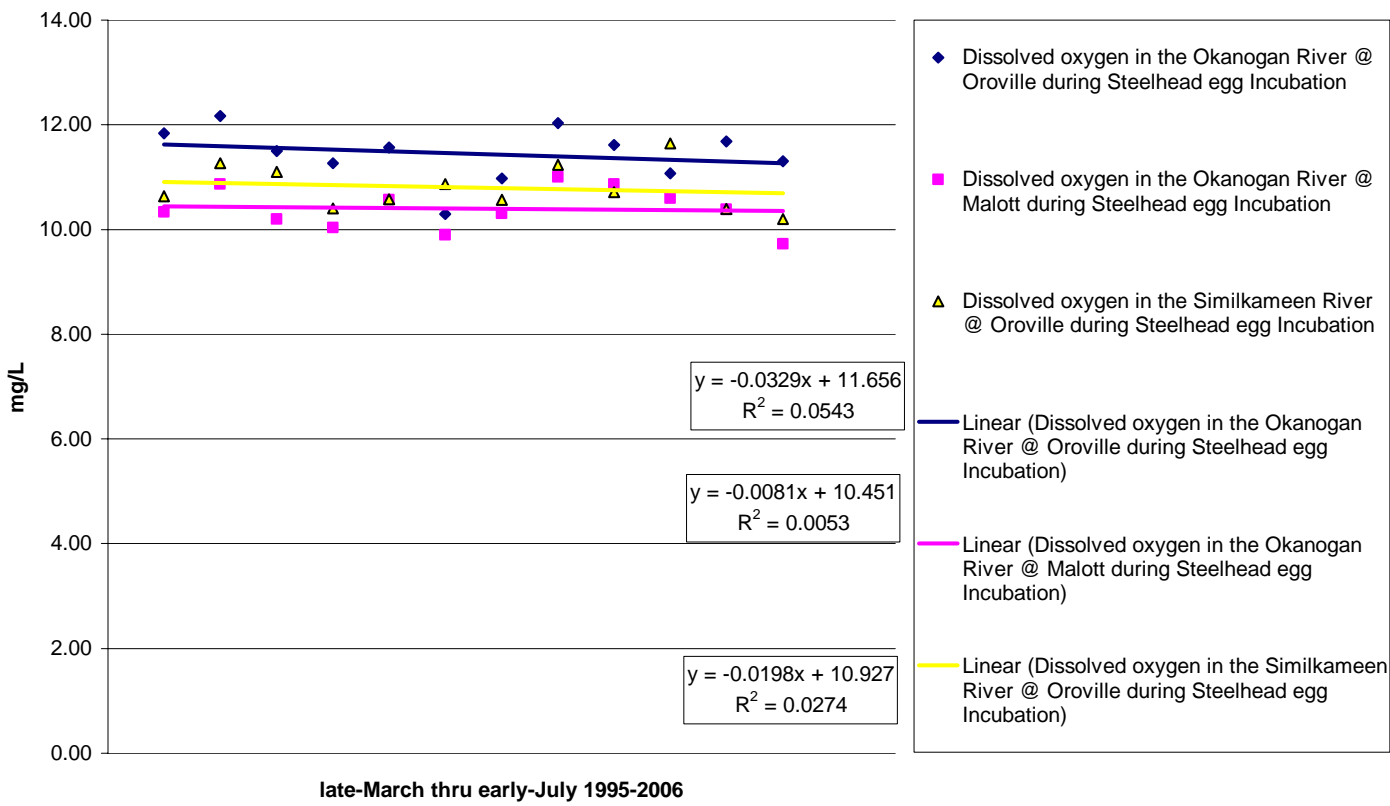

Figure 19. Mean annual dissolved oxygen levels recorded for the period from March through May (when summer steelhead eggs are incubating) from 1995 to 2006. Dissolved oxygen levels represent the mean values that were derived using WDOE grab sample data for the Okanogan River and Similkameen River sites located near the town of Malott, and Oroville, Washington. 


\section{Dissolved Oxygen-Tributary Status}

Temporal patterns of dissolved oxygen levels in the tributaries were similar to those observed along the main stem sites with high levels occurring during cold water months and low levels occurring during the warm water months. Dissolved oxygen levels at tributary sites bottomed out earlier than main-stem sites which is consistent with temperature patterns that show warm temperatures peaking earlier in small tributaries. However, with only one year of data to look at making accurate and meaningful statements is difficult and potentially misleading. However, our data suggests that low dissolved oxygen levels in the tributaries remained above $8 \mathrm{mg} / \mathrm{L}$ throughout 2006. The lowest monthly average reading occurred on Mill Creek and was $8.16 \mathrm{mg} / \mathrm{L}$ along with the second lowest mean value of $8.45 \mathrm{mg} / \mathrm{L}$ which occurred in August. Mill Creek has extensive grazing activities throughout this watershed therefore it is likely that biological oxygen demand is higher for this stream than others. The lowest reading on a perennial stream was $8.91 \mathrm{mg} / \mathrm{L}$ on Salmon Creek during the month of June. All dissolved oxygen readings in tributary streams were within the acceptable parameters for salmonid production (Figure 20).

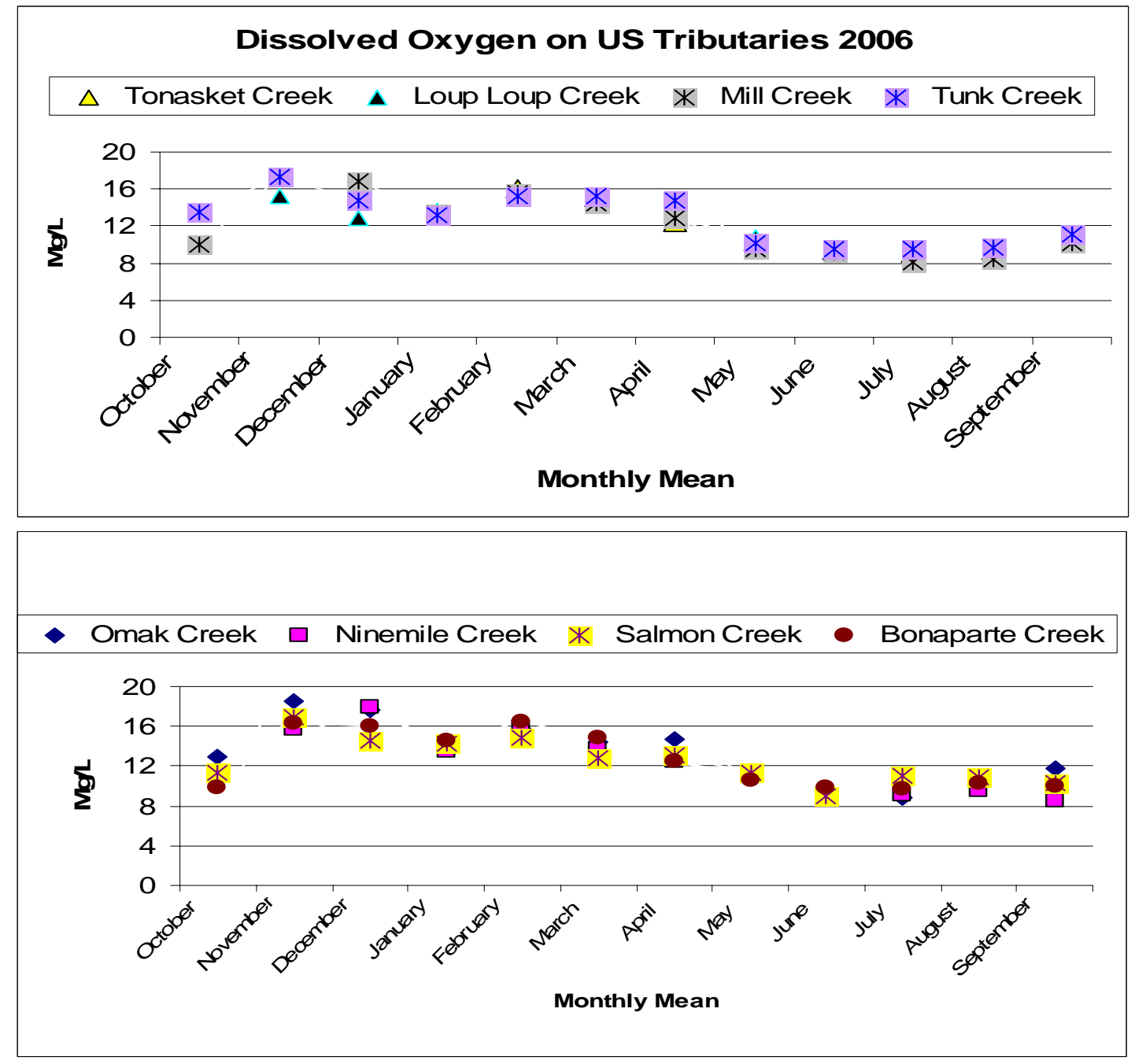

Figure 20: Status data for dissolved oxygen levels collected by OBMEP for the tributary sites sampled in 2006. Top graph represents streams that have sections which are intermittent and bottom graph represents streams that are considered perennial. 


\section{Turbidity}

In most streams, there are periods when the water is relatively turbid and contains variable amounts of suspended sediments (Bjornn and Reiser 1991). Turbidity has been found to be linked to primary productivity $\left(\mathrm{g} \mathrm{O}_{2} / \mathrm{m}^{2}\right)$ and increases from $1 \mathrm{NTU}$ to 170 NTU reduces productivity by $50 \%$ and productivity can be reduced to zero at turbidities of 1,100 NTU or higher (LaPerriere et al 1983, VanNieuwenuyse and LaPerriere 1982). An increase of 25 NTU over normal background levels has been found to reduce primary productivity from 13 to $50 \%$ (Lloyd et al. 1987). Newly emerged salmon and steelhead fry show reduced growth and tend to emigrate from areas were turbidities ranged from 25-50 NTU (Sigler et al. 1984). Juvenile salmon avoid areas with turbidities above 70 NTU whereas older fish appear to be little affected by ephemerally high concentrations of suspended sediments (Bisson and Bilby 1982, Sorenson et al. 1977).

\section{Turbidity-Main-stem Status and Trend}

In 2006, and historically, the Okanogan River exiting Canada had turbidity levels well below any threshold of biological importance, see, Okanogan River at Oroville (Figure 21). This is most likely due to the large lakes that are contained within this watershed that act as very effective sediment traps. Historical averages from the lower Okanogan and Similkameen Rivers show that turbidities from July to March typically occur at levels that would have no impact on salmonids as levels are below 30 NTU throughout this time of the year (Figure 21). The historic twelve year average and 2006 data on the lower Okanogan River at Malott show turbidities from May through June approaching 30 NTU. The Similkameen River in 2006 peaked at 70 NTU in May with historic averages of 30 NTU. Juvenile steelhead and summer/fall Chinook are in the river at this time. The 2006 level of turbidity in the Similkameen had the potential to reduce primary productivity and reduce growth of newly hatched fish. This level may also have been helpful as a catalyst for smolt out-migration as juvenile fish are known to avoid areas with turbidities over 70 NTU.

We looked at the trend in the Okanogan and Similkameen Rivers of the level of turbidity during salmonid egg hatching and smolt outmigration, the months of April thru June. Over the last 12 years, the Okanogan River at Oroville turbidity levels were stable at below 5 NTU's. The Okanogan River site at Malott and the sampling site on the Similkameen River at Oroville had a marginally detectable decreasing trend in turbidity (Figure 22). However, these data were highly variable and appear to be more influenced by the magnitude of spring runoff than by changes in upland conditions or road densities. The rate of change was greatest for the Similkameen River at $-1.2 \mathrm{NTU} / \mathrm{yr}$. A trend toward reduced turbidity would be considered a positive for the Okanogan River and with average values below 40 NTU in all years it is unlikely that turbidity levels are having a negative impact on salmonid populations. 


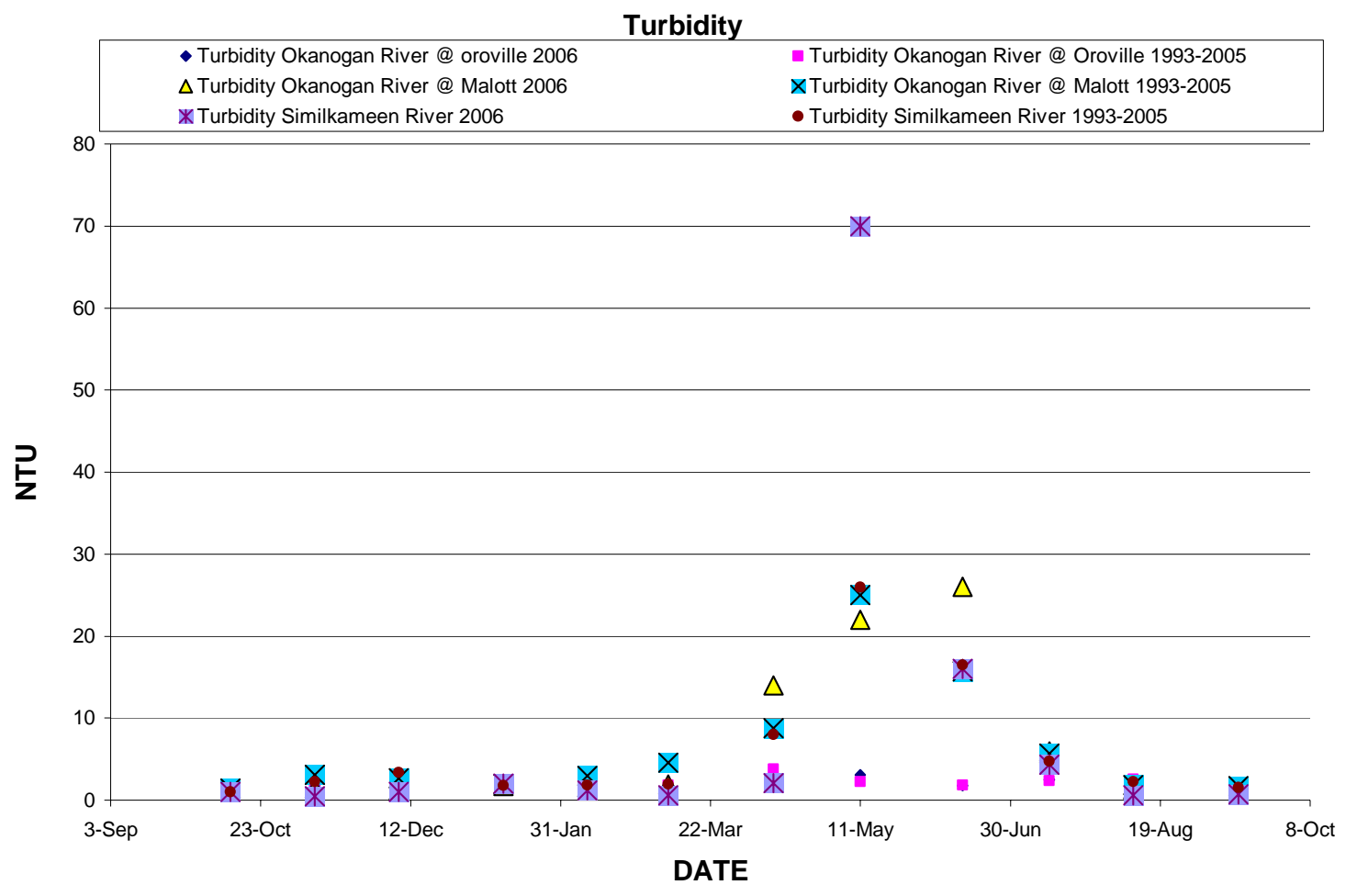

Figure 21. Turbidity levels for the Okanogan River and Similkameen River sites located near the town of Malott, and Oroville, Washington comparing 2006 data to the historical average from 1993 to 2005.

Turbidity 12 Year Trend During Salmonid Egg Hatching and Smolt Outmigration in the Okanogan and Similkameen Rivers

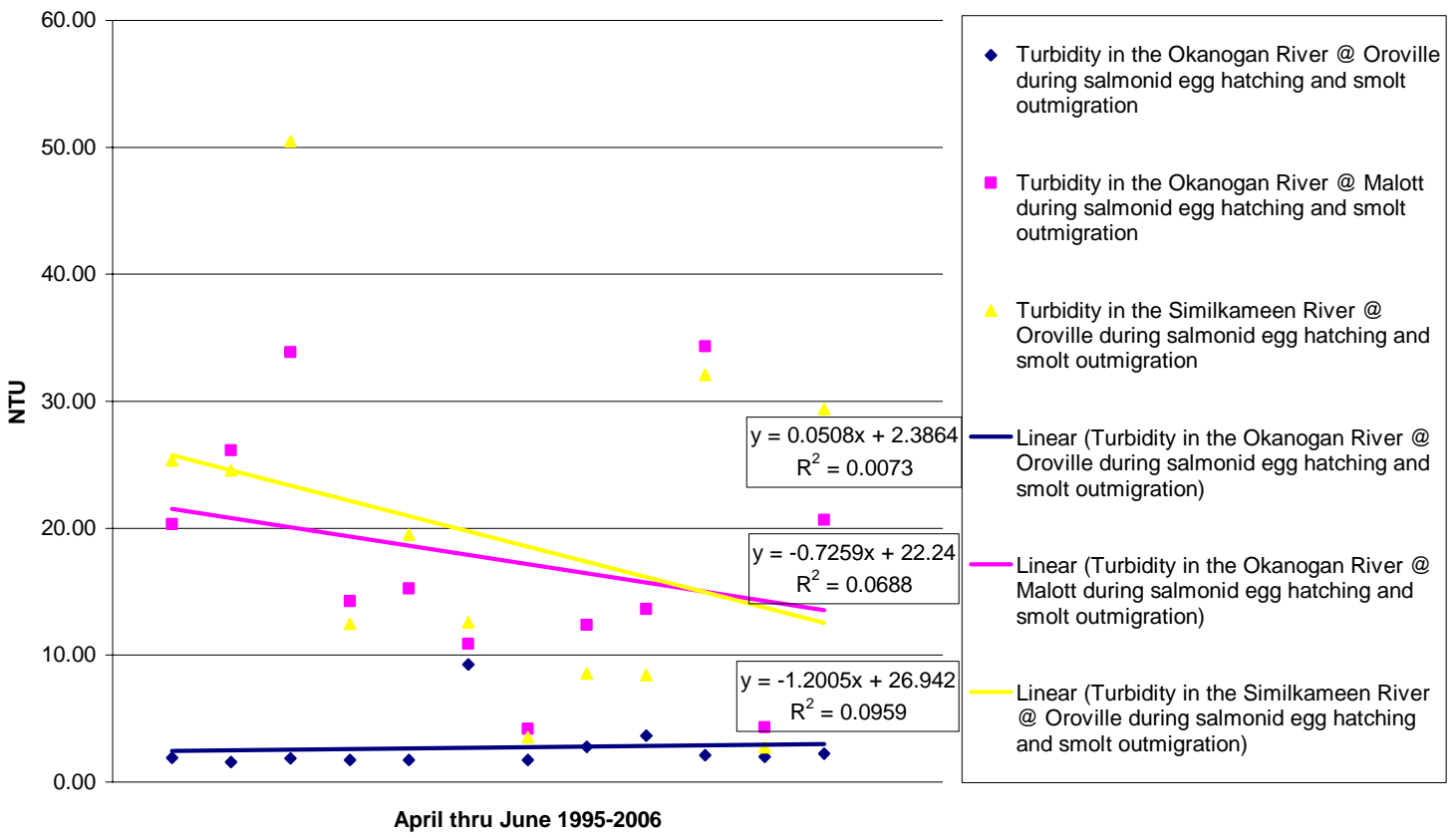

Figure 22. Trend data for turbidity collected from 1995 to 2006 during salmonid egg hatching and smolt outmigration (April through June) by WDOE for the Okanogan River and Similkameen River at sites located near the town of Malott, and Oroville, Washington. 


\section{$\underline{\text { Turbidity-Tributary Status }}$}

We collected data on turbidity levels at OBMEP tributary sites along the Okanogan River in 2006. Grab samples at the tributary sites were collected three times a month and averaged by month and between sites for each of the eight sub watersheds were data were collected (Figure 23). Empirical data at these sites were highly variable when it came to the NTU levels but using averaged data defined more consistent patterns. Turbidity levels peaked during spring runoff and remained low during the low discharge time frame. However, two intermittent tributaries had high turbidity levels during the winter months that are unexplained but likely linked to localized runoff events. Bonaparte and Omak Creek were the only tributaries that had monthly average readings above 70 NTU (Figure 23). Major upland disturbance in the Bonaparte Creek watershed has occurred for decades and agricultural practices within the riparian areas along this creek have lead to major channel incision and bank instability. High sediment loads continue to threaten this watershed and reduce the salmonid productivity of this tributary. Major rehabilitation efforts are needed within the Bonaparte Creek sub watershed to improve salmonid habitats. Within the Omak Creek watershed major sediments loads due to extremely high road densities and years of high sediment inputs will take decades to be processed by natural means. Extensive rehabilitation efforts over the past few years to replace culverts decommission roads, and exclude livestock from riparian areas will help reduce sediment inputs. Measurable changes in turbidity levels are unlikely to occur in the near future.

\section{pH}

The sensitivity of fishes to extremes of $\mathrm{pH}$ varies; however, a range of 6.5-9.0 is recommended for salmonid species (Piper et al. 1982). Environmental $\mathrm{pH}$ affects the toxicity of ammonia, hydrogen sulfide, metals, and other pollutants. Alkalinity is a measure of the buffering capacity of water therefore it has a major impact on the fluctuation of $\mathrm{pH}$ values.

\section{pH-Main-stem Status and Trend}

$\mathrm{pH}$ remained relatively consistent in 2006 when compared to the 1993-2005 average for all the Okanogan and Similkameen rivers sites with one notable exception (Figure 24). During 2006, the $\mathrm{pH}$ values for the Similkameen River dropped to near 7 in April and the exact cause of this remains unknown. However, this value was still within the recommended range for salmonid species.

The 12 year trends for $\mathrm{pH}$ indicate that levels are remaining stable along the entire Okanogan River (Figure 25.). However, within the Similkameen drainage dramatic annual changes in the mean $\mathrm{pH}$ values have occurred resulting in a declining trend for $\mathrm{pH}$ at a rate of $-0.024 \mathrm{pH}$ units/yr. The high variability in these data could be the result of sporadic acidic inputs or a lack of sufficient buffering to stabilize this indicator. The long history and present day mining activities within the Similkameen drainage have the potential to produce point sources of a highly acidic nature. Sporadic releases from mining activities would closely mimic the data that we observed in figure 25 but the sources of these inconsistent acidic release sights remain unknown. Other possible 
explanations for the acidification occurring within the Similkameen drainage might include such things as increased densities of conifer trees or acid rain but both would be more likely to result in gradual changes in average $\mathrm{pH}$ levels. Although $\mathrm{pH}$ values are within the optimal range for salmonids localized impacts from acidic point sources could negatively impact salmonid production within the Similkameen River and warrant further investigation.
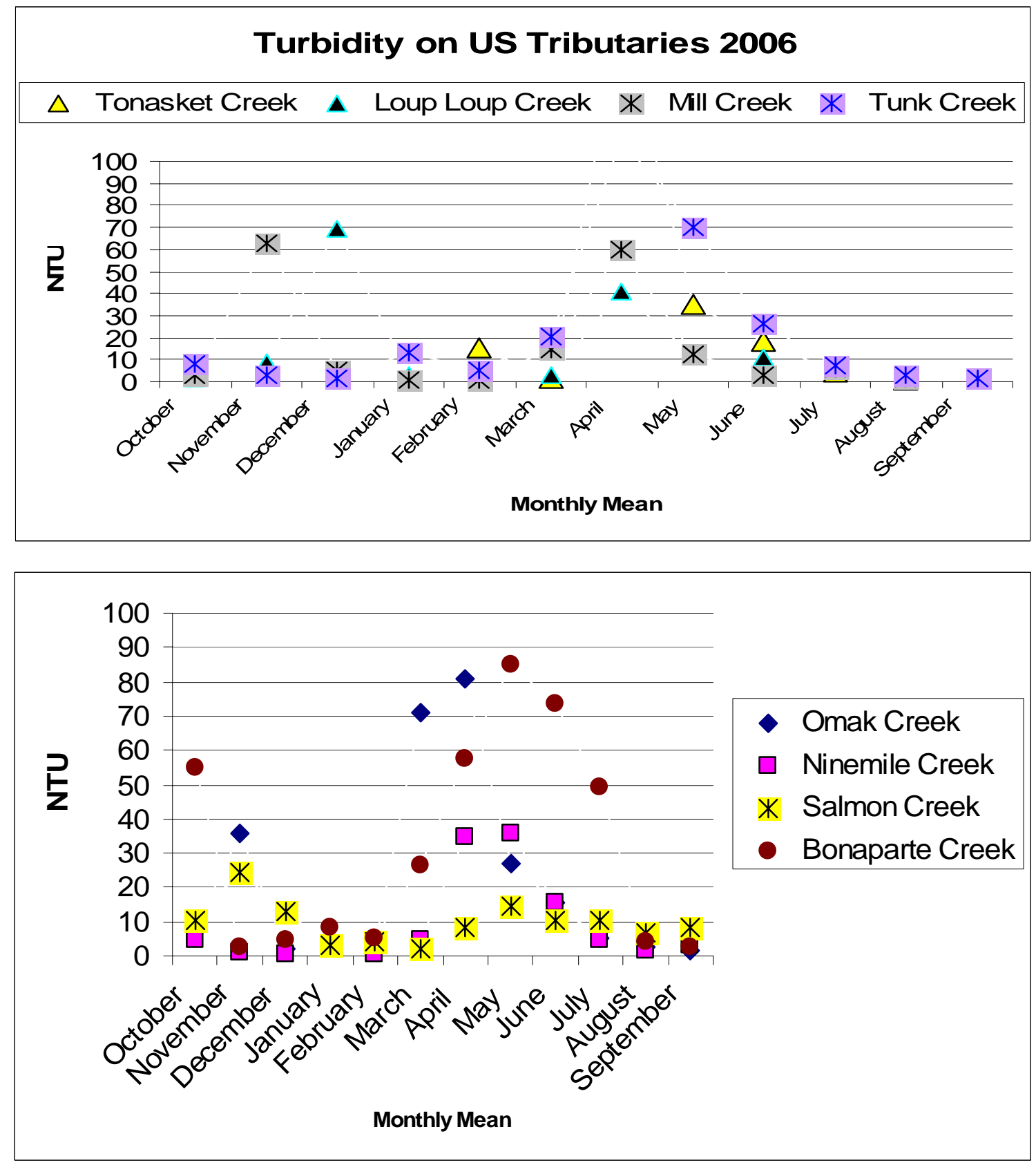

Figure 23. Average monthly turbidity for 2006 from 8 tributary sub watersheds within the Okanogan River basin. 


\section{pH-Tributary Status}

$\mathrm{pH}$ was consistently within the recommended range for salmonid fish species at all the OBMEP tributary sites surveyed by the Colville Tribes during 2006 (Figure 26). The lack of fluctuation between space and over time indicates that these tributaries have excellent buffering characteristics that protect them from fluctuating $\mathrm{pH}$ levels. With a stable reading for $\mathrm{pH}$ between 7.2 and 8.7 these waters would be considered weakly basic and excellent for invertebrates and fish (Figure 26). The stability of $\mathrm{pH}$ values means that $\mathrm{pH}$ levels are likely to remain so in the future. Monitoring efforts for this indicator could be reduced to the most downstream site within each sub watershed if data are to be collected in the future.

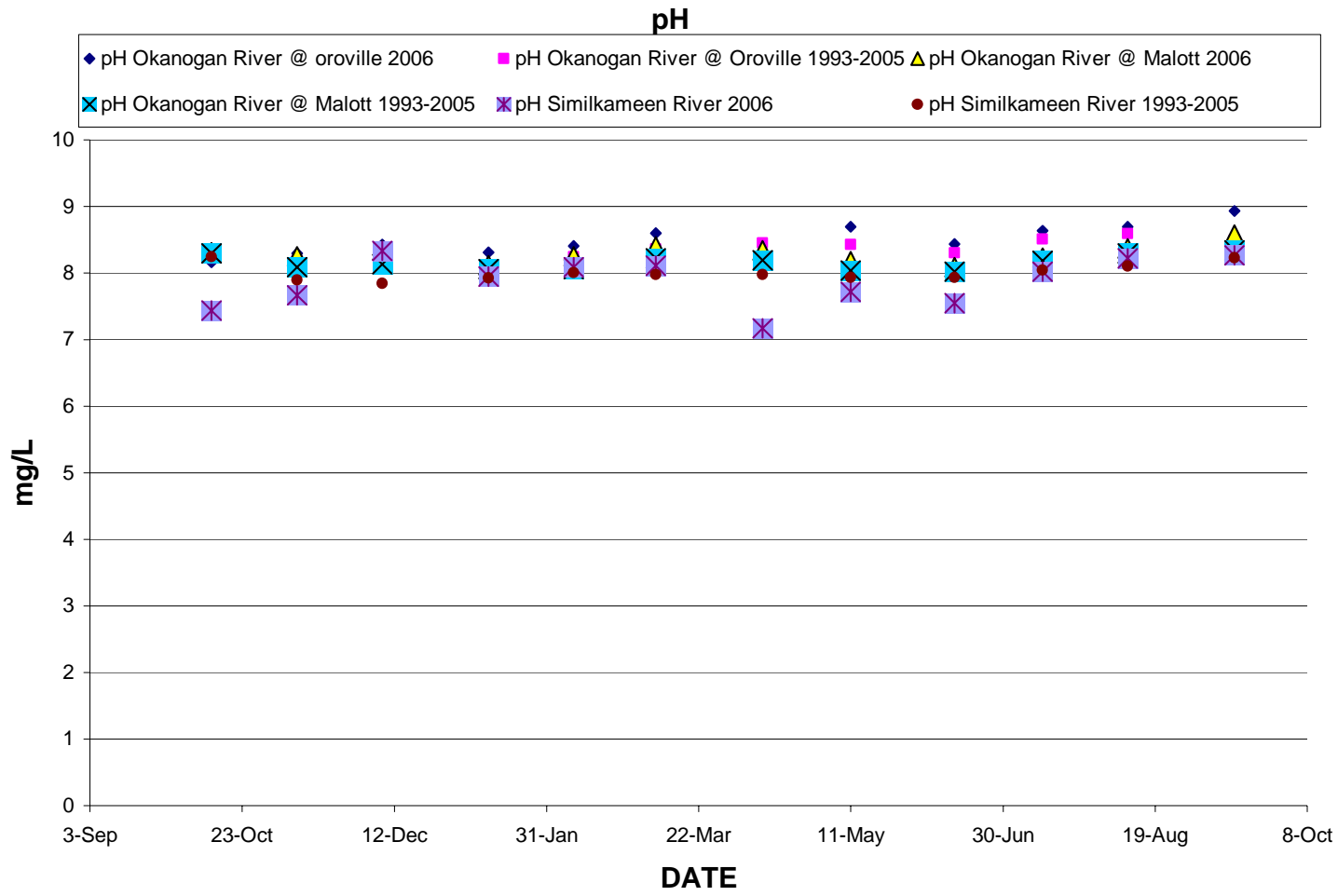

Figure 24. Status data for $\mathrm{pH}$ comparing 2006 values to the average values recorded from 1993 to 2005 on the upper Okanogan River and Similkameen River site located at the town of Oroville, WA, and the lower Okanogan River site near the town of Malott, WA. 
pH 12 Year Trend in the Okanogan and Similkameen Rivers

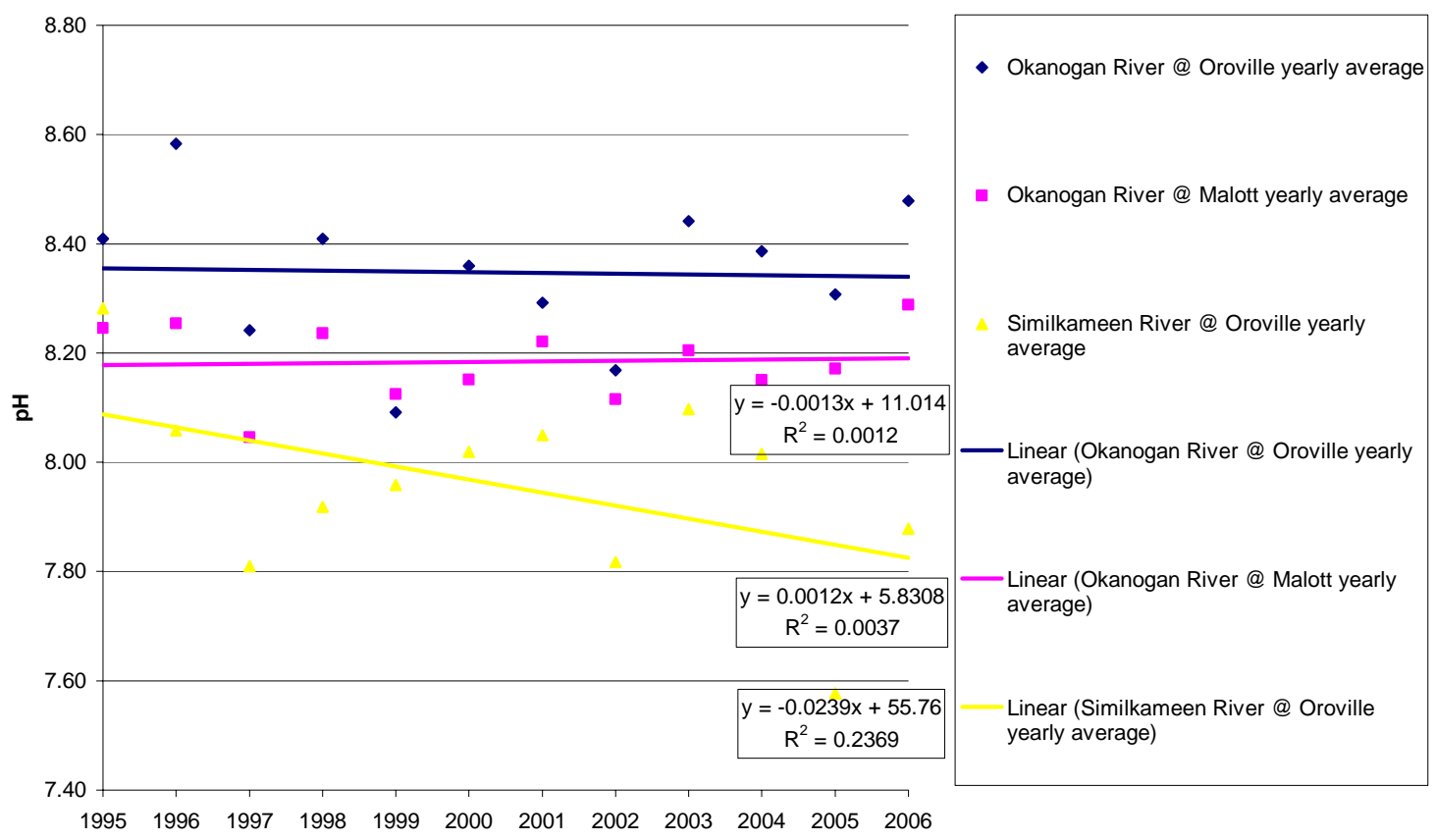

Figure 25. Mean annual pH values collected at WDOE sites along the Okanogan River and Similkameen River near the towns of Malott, and Oroville, Washington over a 12 year period from 1995 to 2006.

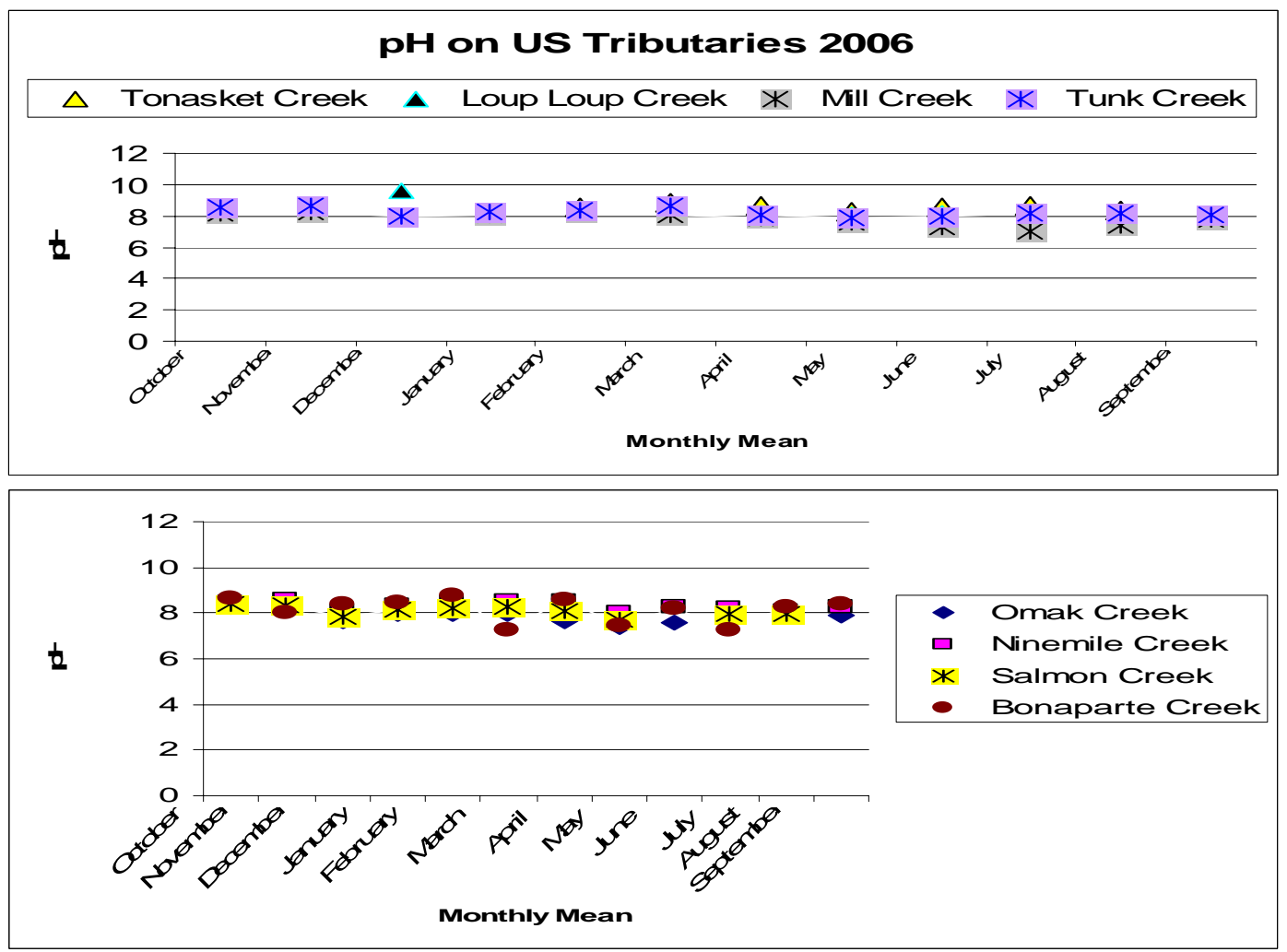

Figure 26. Mean monthly $\mathrm{pH}$ values for 8 tributary sub watersheds within the Okanogan River basin derived from data collected by the Colville Tribes during 2006. 


\section{Ammonia}

Ammonia in its un-ionized form $\left(\mathrm{NH}_{3}\right)$ is highly toxic to fish but the ionized form, $\left(\mathrm{NH}_{4}{ }^{+}\right)$usually referred to as ammonium is not toxic. The amount of each form found in water is mainly influenced by the ionic concentration, $\mathrm{pH}$, and temperature of the water. If the $\mathrm{pH}$ is below 7 no un-ionized ammonia exists. On the Okanogan River, $\mathrm{pH}$ may reach 8.8 (Figure 27) and temperature can exceed $20^{\circ} \mathrm{C}$ (Figure 36) during the months of July and August therefore as much as $20 \%$ of the ammonia-nitrogen measured could be in the un-ionized form.

Salmonids are known to be highly sensitive to ammonia $\left(\mathrm{NH}_{3}\right)$ toxicity and concentrations below $0.03 \mathrm{mg} / \mathrm{L}$ are considered optimal (Wedemeyer 1996). Ammonia concentrations between 0.05 and $0.2 \mathrm{mg} / \mathrm{L}$ are not typically considered lethal for salmonids but have been shown to significantly reduce growth (Wedemeyer 1996) and long-term exposures can cause physiological and histopathological effects along with gill hyperplasia that can result in indirect mortalities (Piper et al. 1982, Burrows 1964). The literature shows the minimum lethal level for ammonia, $\mathrm{NH}_{3}$, for rainbow trout is 0.2 $\mathrm{mg} / \mathrm{L}$ (Norris et al 1991) however the instantaneous mortality concentrations are more widely believed to occur at levels greater than $0.32 \mathrm{mg} / \mathrm{L}$ for salmonids (Summerfelt et al 2001).

Values recorded by WDOE are for ammonia-nitrogen which is a measure of total ammonia in both ionized and un-ionized form. Because only the un-ionized form has a bearing on fish health and given the information already documented for the Okanogan and Similkameen Rivers ( $\mathrm{pH}$, temperature) a maximum of $20 \%$ of the measured ammonium-nitrogen would be found in the un-ionized form (Piper et al. 1982). Concentrations of ammonia-nitrogen should not exceed $0.15 \mathrm{mg} / \mathrm{L}$ of optimum water quality (Piper et al. 1982). Ammonia-nitrogen levels below $0.25 \mathrm{mg} / \mathrm{L}$ are unlikely to result in any adverse impacts to salmonids and levels below $1 \mathrm{mg} / \mathrm{L}$ are unlikely to have any impact during months outside of the June through September period.

\section{$\underline{\text { Ammonia-Main-stem Status and Trend }}$}

In 2006, the highest recorded values of ammonia-nitrogen occurred in October for the Okanogan River $(0.032 \mathrm{mg} / \mathrm{L})$ and for the Similkameen River $(0.040 \mathrm{mg} / \mathrm{L})$. However, during the cold water months much less of the unionized form that is toxic to fish is present. During the warmer water months from June through September both historically and in 2006 all readings were less than $0.015 \mathrm{mg} / \mathrm{L}$ which is well below any levels considered harmful to salmonids (Figure 27). Historically, ammonia readings along the Okanogan and Similkameen rivers have shown very minor variation at all sites and over time. The reason for the increased level of ammonia-nitrogen in October of 2006 is unknown but levels are still below those that would represent a negative impact to salmonid fish species (Figure 27). The most common reading during all the hot summer months since 1994 is 0.01 or less and this represents the lowest reading possible given the methodology employed by WDOE therefore the actual values are likely to be less. After

analyzing data on this indicator for 12-years at the WDOE sites ammonia levels have 
been well below any levels that would have any biological impact, this brings into question the value of continued monitoring for this indicator.

We conducted a trend analysis on the mean annual values for ammonia and found that over the last 12 years the Similkameen River had remained definitively stable (Figure 28). However, data was more varied for the Okanogan River especially near Oroville, WA where at first glance it would appear that a trend existed; statistics show that no discernible trend existed. At the Malott site on the Okanogan River a marginally detectable declining trend does exist with ammonia levels declining at a very slow rate of $-0.002 \mathrm{mg} / \mathrm{L} / \mathrm{yr}$. With a trend toward lower levels and because current levels are well below those that would have any impact on salmonids continued monitoring of this indicator for salmonids is of questionable value.

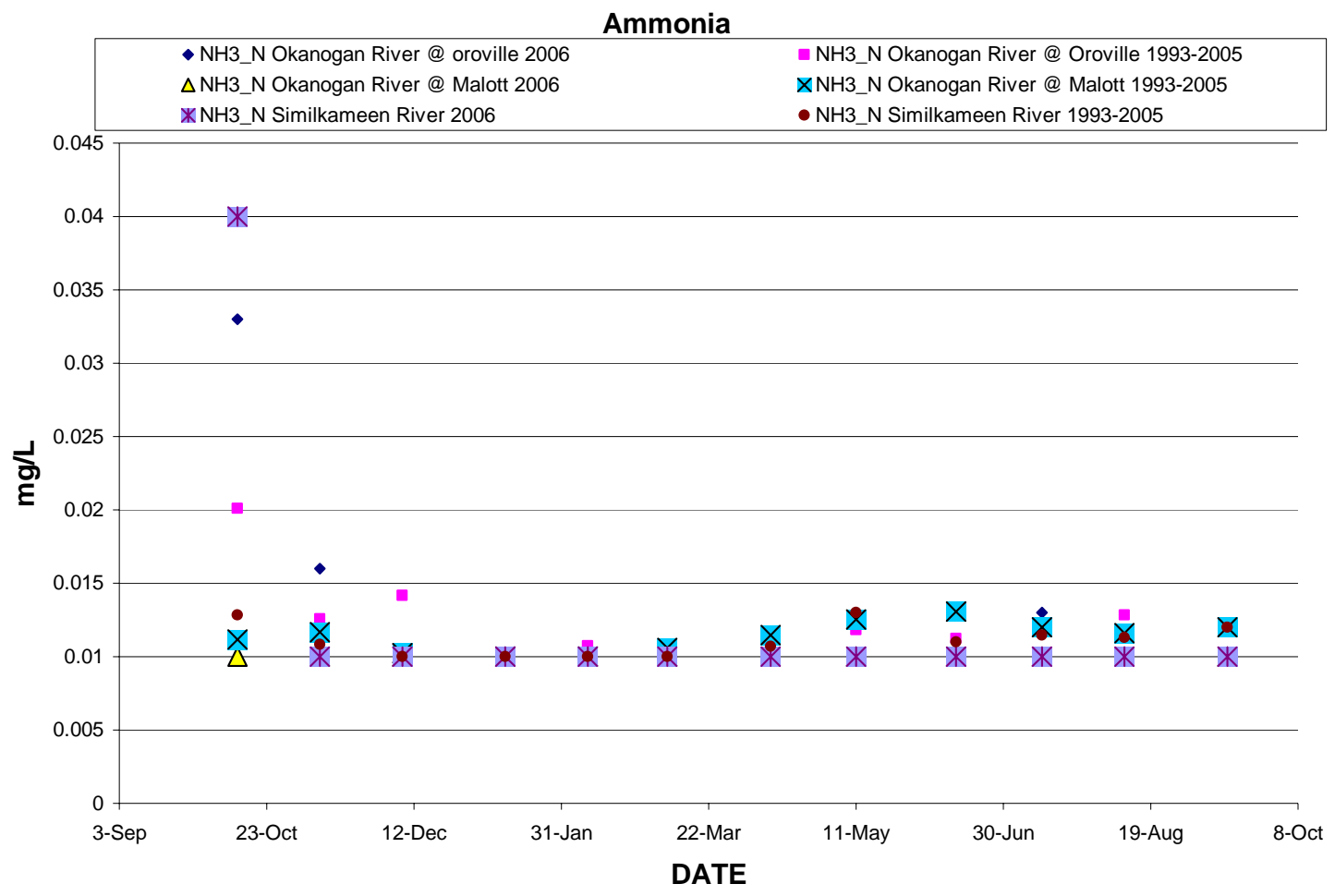

Figure 27. Status data collected in 2006 for Ammonia-nitrogen compared to the historical average from 1993 to 2005 at WDOE sites along the Okanogan River near the town of Malott, and Oroville, WA and the Similkameen River near Oroville, WA. 


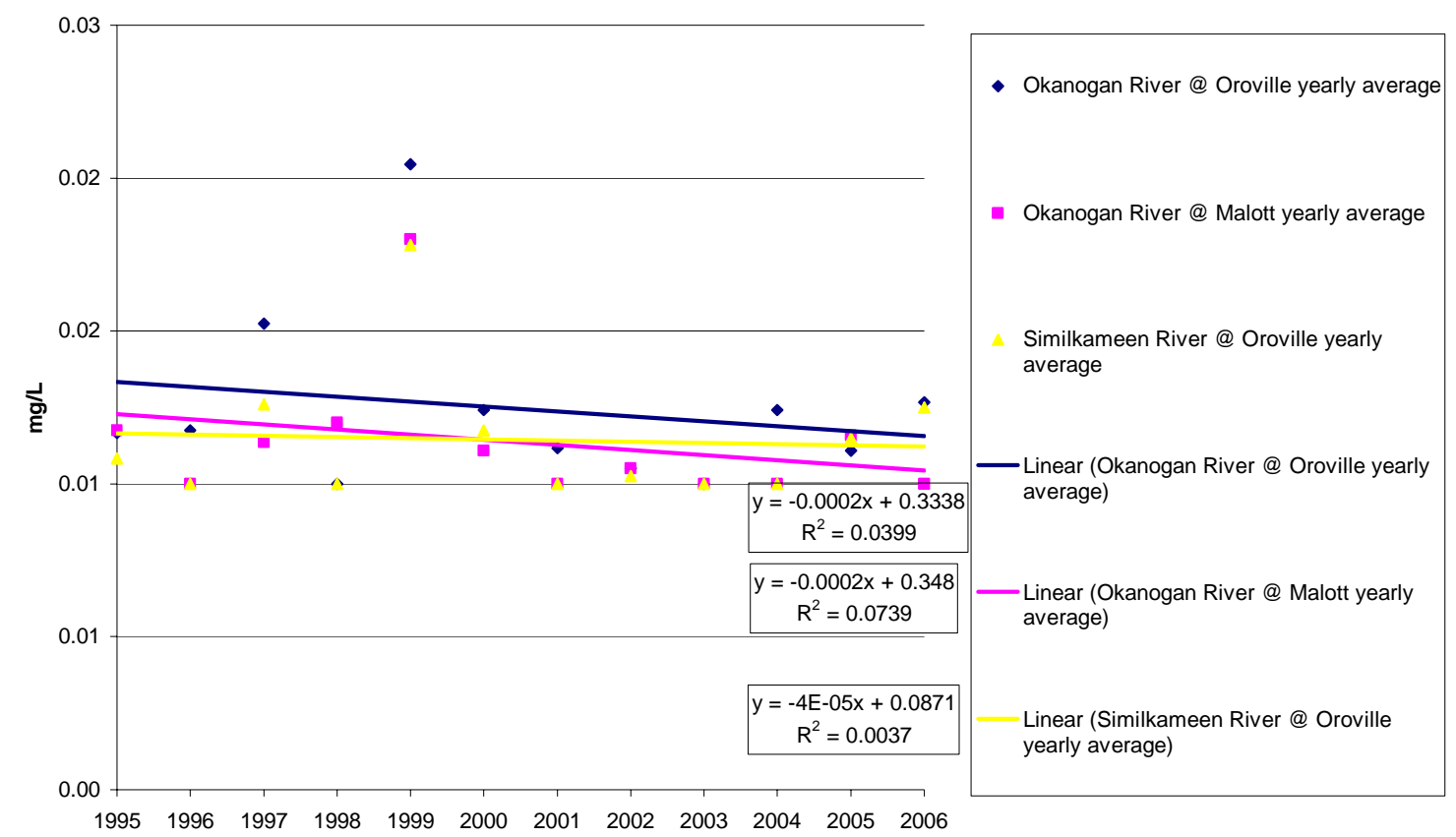

Figure 28. Mean annual trend data for Ammonia (NH3_N) over the 12 year period from 1995 to 2006 for WDOE sites located on the Okanogan River and Similkameen Rivers.

\section{Nitrogen and Phosphorus}

Total nitrogen is measured by WDOE at sites along the Okanogan and Similkameen rivers and consists of both Nitrite $\left(\mathrm{NO}_{2}\right)$, and Nitrate $\left(\mathrm{NO}_{3}\right)$. Nitrogen is an oxidation product of mainly ammonia in aquatic systems and the primary source of these nutrients is from erosion, fish waste, other biological processes, and both inorganic and organic fertilizers. Nitrogen nutrients are transformed by autotrophic bacteria from ammonia to nitrite to nitrate. Ammonia and nitrite are both toxic for fish but nitrate is not. However, for nitrite to be toxic it must be diffused across the gill membrane in the form of nitrous acid $\left(\mathrm{HNO}_{2}\right)$. Along the Okanogan River, only Nitrite is of possible concern and this form can only enter freshwater fish by the active chloride pump system (Summerfelt et al. 2001). Nitrite oxidizes the iron in hemoglobin, reducing oxygen transport of blood and can cause asphyxiation even when dissolved oxygen levels are not limiting (Russo and Thurston 1991). Nitrite toxicity is known as "brown blood disease" and is dependent on species, life stage, and the concentration of other ions especially chloride and calcium (Russo et al. 1981, Russo and Thurston 1991, and Wedemeyer 1996). Nitrite is more toxic for salmonids than other fish and can kill rainbow trout at concentrations above 0.2$0.4 \mathrm{mg} / \mathrm{L}$ (Wedemeyer 1996). The presence of dissolved chloride or calcium at concentrations of at least $50 \mathrm{mg} / \mathrm{L}$ can increase fish tolerance to nitrite by 50 fold.

Phosphorus is not considered to be toxic for fish at levels that are likely to be found in aquatic systems. However, the ecological relationships between nitrogen and phosphorous can increase or hinder fish growth by $50 \%$ due to increased algal growth. 
The ratio of nitrogen and phosphorus $(\mathrm{N}$ : $\mathrm{P})$ is used to determine which nutrient is limiting a given system. A ratio of 10 or less means that nitrogen is limiting while levels above 10 indicate phosphorus limited systems. Only the nutrient that is limiting is of biological value as the level of the other nutrient that is usable is constrained by the limiting nutrient.

In the Okanogan basin, we have phosphorous levels that are occasionally up to twice as high as nitrogen levels and $\mathrm{N}$ : P ratios remain well below the threshold of 10:1 during all times of the year (Figure 29-32). Nitrogen is always limiting in the Okanogan and Similkameen rivers from the Canadian border to the confluence with the Columbia River. Future monitoring should continue to be focused on nitrogen levels and more specifically nitrite levels as these would have the most potential for biological impacts on salmonids.

\section{Nitrogen and Phosphorus-Main-stem Status and Trend}

The status of nitrite as measured by WDOE is consistently from 2 to 10 times below any potentially harmful level and has been since 1993. However, the measurements taken at WDOE sites include both nitrite and nitrate so direct measurement of this indicator is not possible and the specific proportion of each can only be estimated at present. Specific nitrite levels are likely 4 to 20 times below the levels currently monitored (Figure 29). Peak nitrogen nutrient loads on the Okanogan River in January likely result from salmon carcass decay. The magnitude of nitrogen levels in 2006 on the Okanogan and Similkameen rivers were up to five times less than average nitrogen levels from 19932005 (Figure 29). Between sites the highest readings both historically $(0.095 \mathrm{mg} / \mathrm{L})$ and in $2006(0.067 \mathrm{mg} / \mathrm{L})$ occurred at the Okanogan River site near Malott with the lowest reading for all sites in 2006 being $0.01 \mathrm{mg} / \mathrm{L}$.

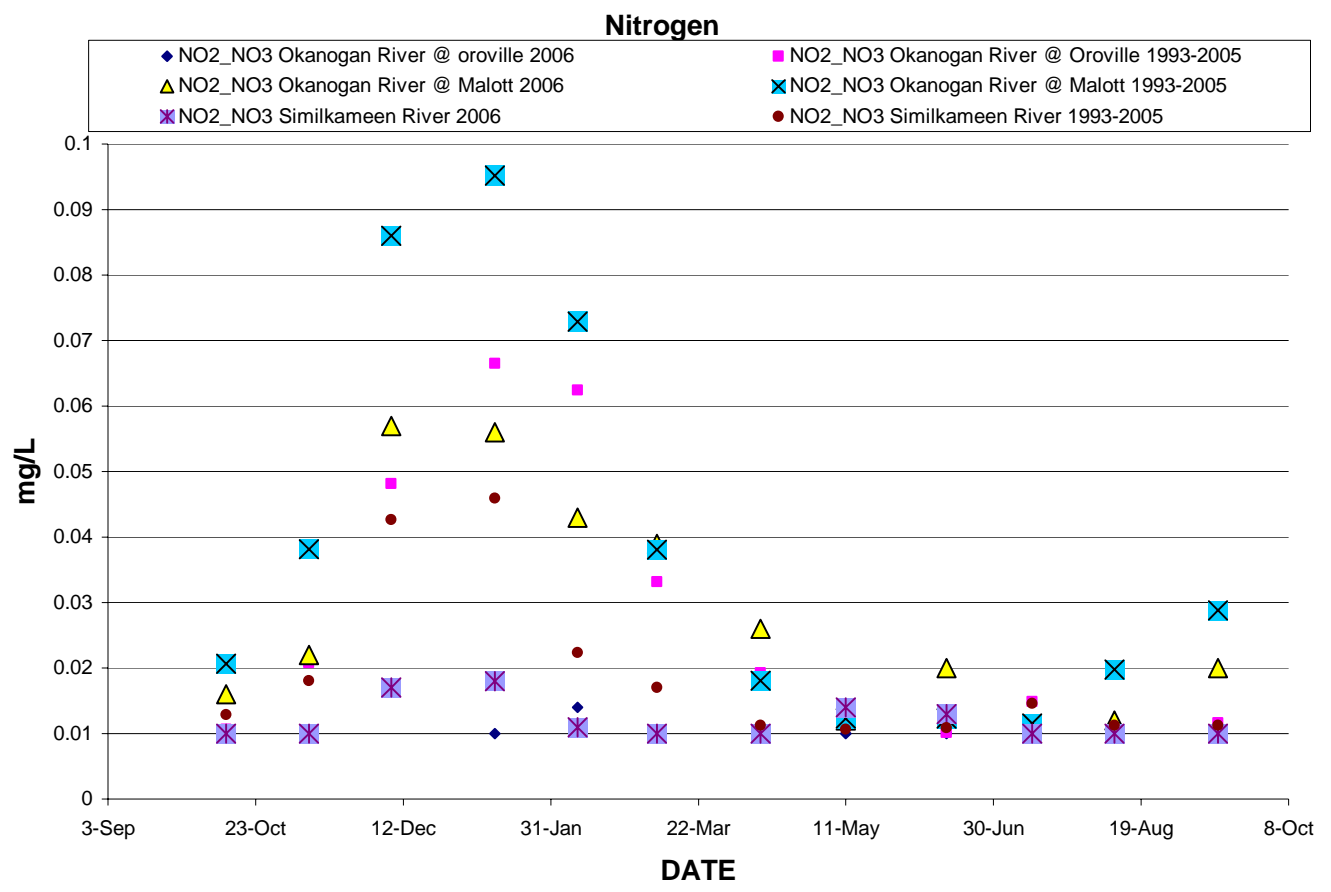

Figure 29. Status data for total nitrogen (nitrate + nitrite) comparing 2006 to the historical average readings from 1993 to 2005 collected at WDOE sites located along the Okanogan River near the town of Malott, and Oroville, WA and the Similkameen River near Oroville, WA. 
Although not limiting, phosphorous levels have been measured at the WDOE sites over the last 12 years of interest (Figure 30). Peak phosphorous nutrient loads typically occur from April through June as water runs off upland areas during the spring. The magnitude of phosphorous levels in 2006 on the Okanogan and Similkameen rivers were approximately half the average phosphorous levels recorded from 1993-2005 (Figure 29). Between sites the highest reading both historically and in 2006 occurred at the Okanogan River site near Malott with the exception during the peak runoff period when the highest values $(0.0923 \mathrm{mg} / \mathrm{L})$ were recorded at the Similkameen River site. The lowest readings $(0.0023 \mathrm{mg} / \mathrm{L})$ occurred at the Similkameen River site during most of the year except during peak runoff when the lowest phosphorous readings $(0.0071 \mathrm{mg} / \mathrm{L})$ were recorded at the Okanogan River site near Oroville.

We found that in the last 12 years mean annual nitrogen values for all sites were trending slightly downward (Figure 31). The Okanogan River at Malott showed the greatest rate of decline at $-0.0015 \mathrm{mg} / \mathrm{L} / \mathrm{yr}$. Mean annual phosphorous levels throughout the Okanogan subbasin are trending slightly downward with the highest rate of change $(-0.003 \mathrm{mg} / \mathrm{L} / \mathrm{yr})$ occurring on the Similkameen River (Figure 32). The reduction in phosphorous levels is likely related to changes in land use practices such as reduced use of fertilizers. Over the past 12 years the ratio of $\mathrm{N}$ : P has moved toward a more nitrogen limiting system.

Causative mechanisms for changes in nitrogen levels are currently not well understood.

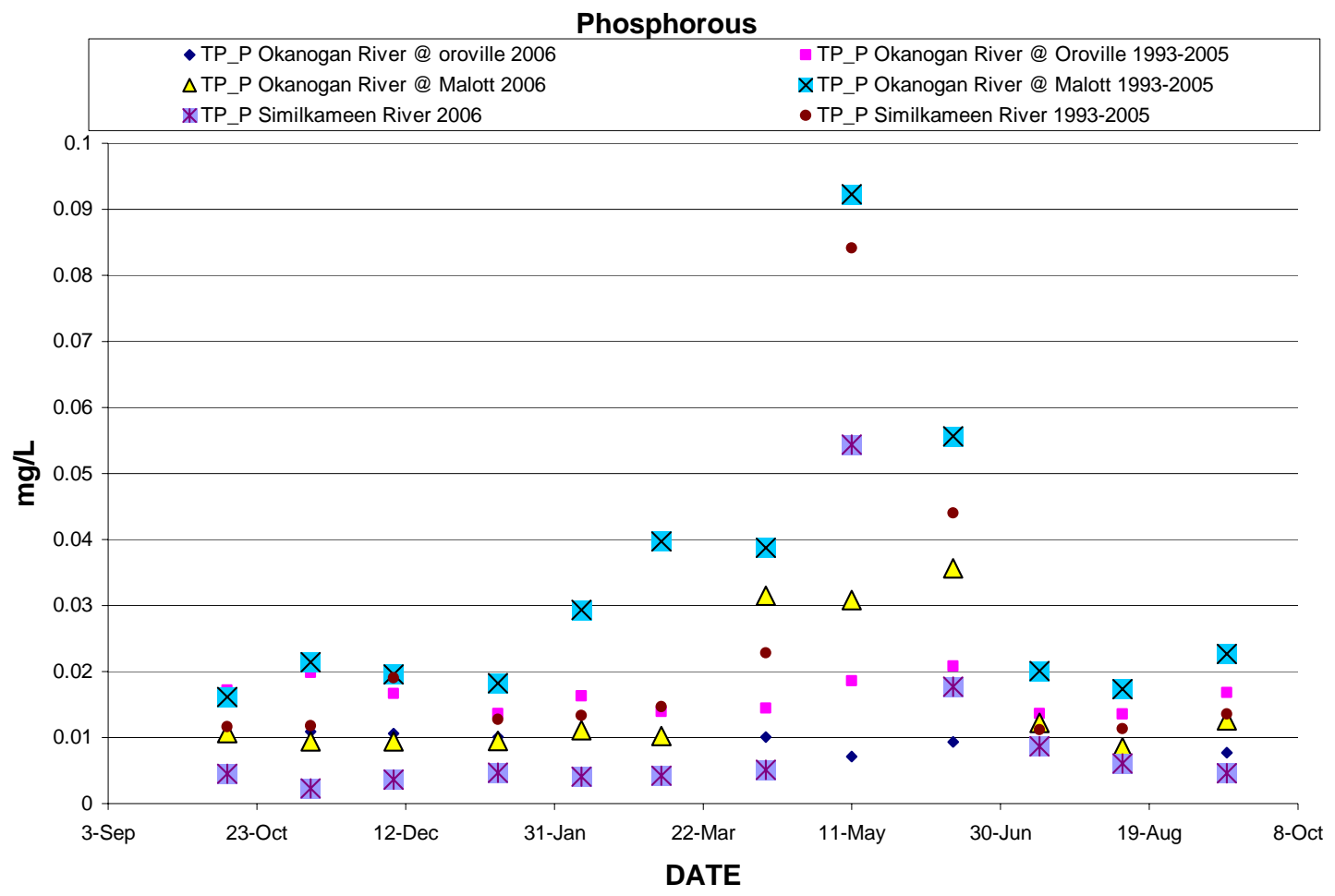

Figure 30. Status data for total phosphorous comparing 2006 to the historical average readings from 1993 to 2005 collected at WDOE sites located along the Okanogan River near the town of Malott, and Oroville, WA and the Similkameen River near Oroville, WA. 
Nitrogen (NO2_NO3) 12 Year Trend in the Okanogan and Similkameen Rivers

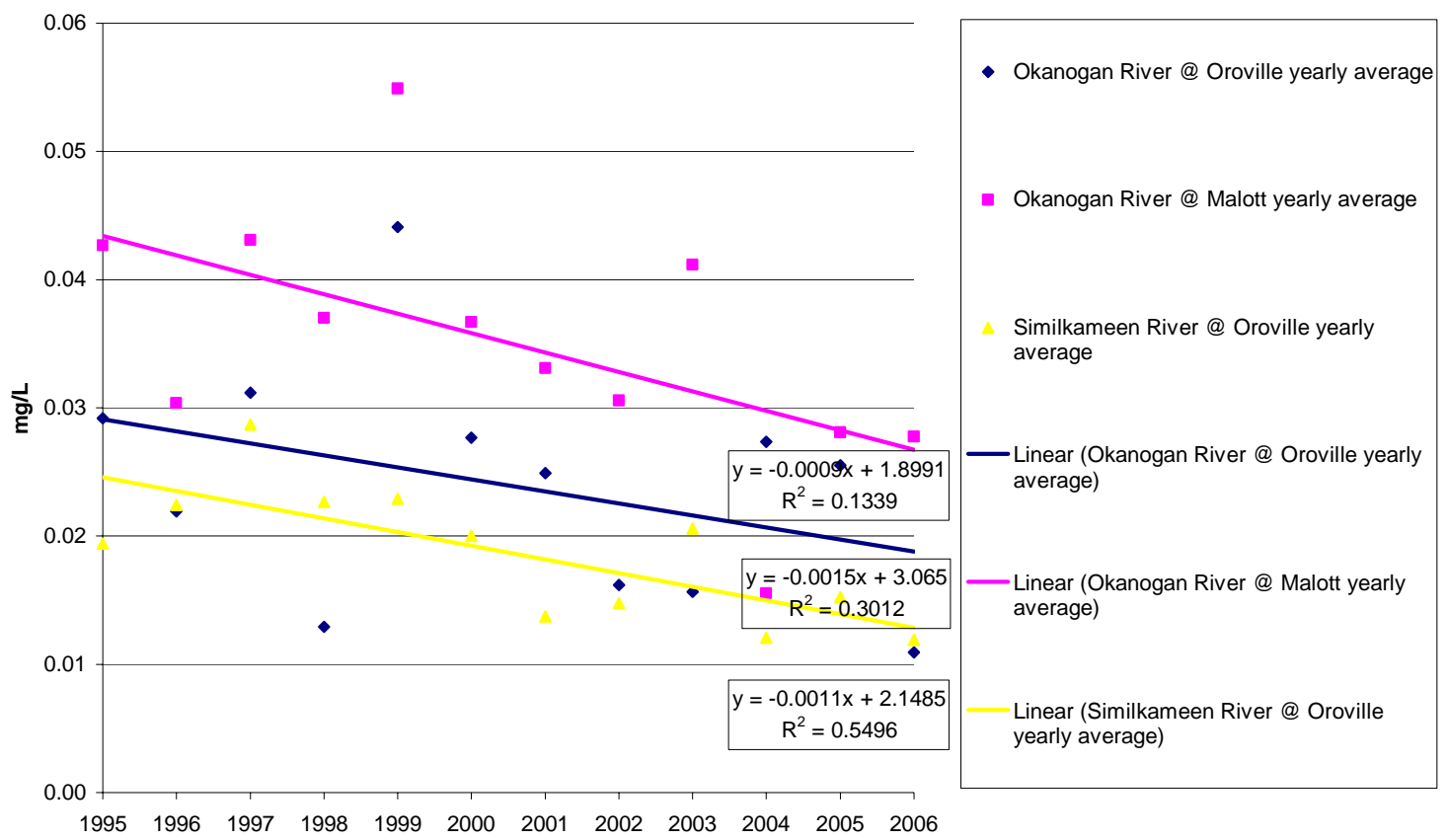

Figure 31.. Mean annual total nitrogen (NO2_NO3) trend during the 12 year period from 1995 to 2006 collected from the Okanogan and Similkameen rivers.

\section{Phosphorous (TP_P) trend in the Okanogan and Similkameen Rivers}

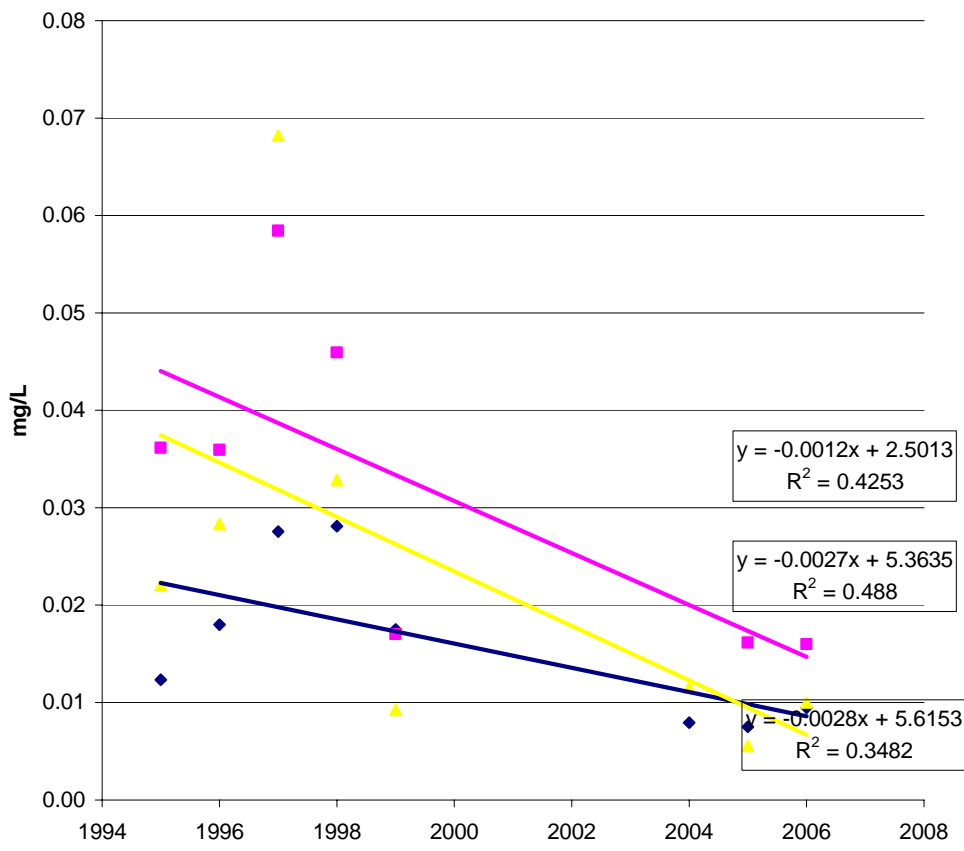

- Okanogan River @ Oroville yearly average

- Okanogan River @ Malott yearly average

Similkameen River @ Oroville yearly average

_Linear (Okanogan River @ Oroville yearly average)

_ Linear (Okanogan River @ Malott yearly average)

Linear (Similkameen River @ Oroville yearly average)

Figure 32. Mean annual total phosphorous (TP_P) trend during the 12 year period from 1995 to 2006 collected from the Okanogan and Similkameen rivers. 


\section{Conductivity}

Specific conductance in water is directly related to total ionic concentrations and to a much smaller degree this indicator is modified by water temperature. Water containing mostly inorganic compounds conduct electricity better than those containing mostly organic compounds because the later are more likely to dissociate in solution (APHA 1992). Distilled water has very low conductivity $(0.5-3.0 \mu \mathrm{S} / \mathrm{cm})$, freshwater typically has conductivity ratings from $50 \mu \mathrm{S} / \mathrm{cm}$ to $1,500 \mu \mathrm{S} / \mathrm{cm}$, and seawater is typically 500 times more conductive (Reynolds 1996). "Conductivity has been shown to have an effect on fish production, however, it's important to remember that these are only correlations (i.e., they do not demonstrate cause and effect). It is more than likely, both fish production and conductivity vary directly with some other covariate or covariates that would more directly explain these effects on fish production" (Tracy Hillman personal communication). Water conductivity is the most important environmental factor that impacts electrofishing. Extremely low conductivity such as below $20 \mu \mathrm{S} / \mathrm{cm}$ results in electro fishing devices being unable to cause involuntary muscle contractions but this can be remedied with the addition of sodium chloride. High conductivities such as above $1,500 \mu \mathrm{S} / \mathrm{cm}$ typically exceed the capacity of most electrofishing power sources (Reynolds 1996). NOAA Fisheries recommends not using electrofishing devices for collecting salmonids at conductivities above $350 \mu \mathrm{S} / \mathrm{cm}$ due to increasing concerns over potentially harmful side effects.

\section{Conductivity-Main-stem Status and Trend}

In 2006 readings on the Okanogan River at Malott, WA varied from $110 \mu \mathrm{S} / \mathrm{cm}$ in June to $339 \mu \mathrm{S} / \mathrm{cm}$ in September (Figure 33) and these readings were slightly higher than the 12year moving average. The Similkameen River near Oroville, WA, consistently had lower conductivity than the Okanogan River and readings in 2006 were slightly lower than the averages for the period from 1993 through 2005 (Figure 33). In 2006, the lowest conductivity reading was $80 \mu \mathrm{S} / \mathrm{cm}$ in June at the Similkameen site and the highest reading was $339 \mu \mathrm{S} / \mathrm{cm}$ in September at the Okanogan River site near Malott. During the spring runoff period (April through June) ionic concentrations become diluted especially on the Similkameen River and the Okanogan River downstream of its confluence resulting in lower conductivity during this period. The regulation of flow at Zosel Dam minimizes changes in conductivity on the Okanogan River near Oroville. Conductivity levels recorded at main-stem monitoring sites are unlikely to have any impact on salmon or steelhead survival or production.

The mean annual conductivity trend of the Okanogan River site located near Oroville, WA showed increasing conductivity levels over the last 12-years at a rate of $4.33 \mu \mathrm{S} / \mathrm{cm} / \mathrm{yr}$. The cause for these increased ionic concentrations is likely tied to the reduction in discharge documented earlier but direct causal mechanisms remain unknown (Figure 34). The Similkameen River has had very stable specific conductance readings over the last 12 years. The Okanogan River near Malott, WA appears to be intermediate between the other two forks and shows a slightly increasing trend. It is unlikely that the levels documented and rates of change in conductivity throughout the Okanogan River subbasin will have any meaningful impact on salmonid survival or production. 


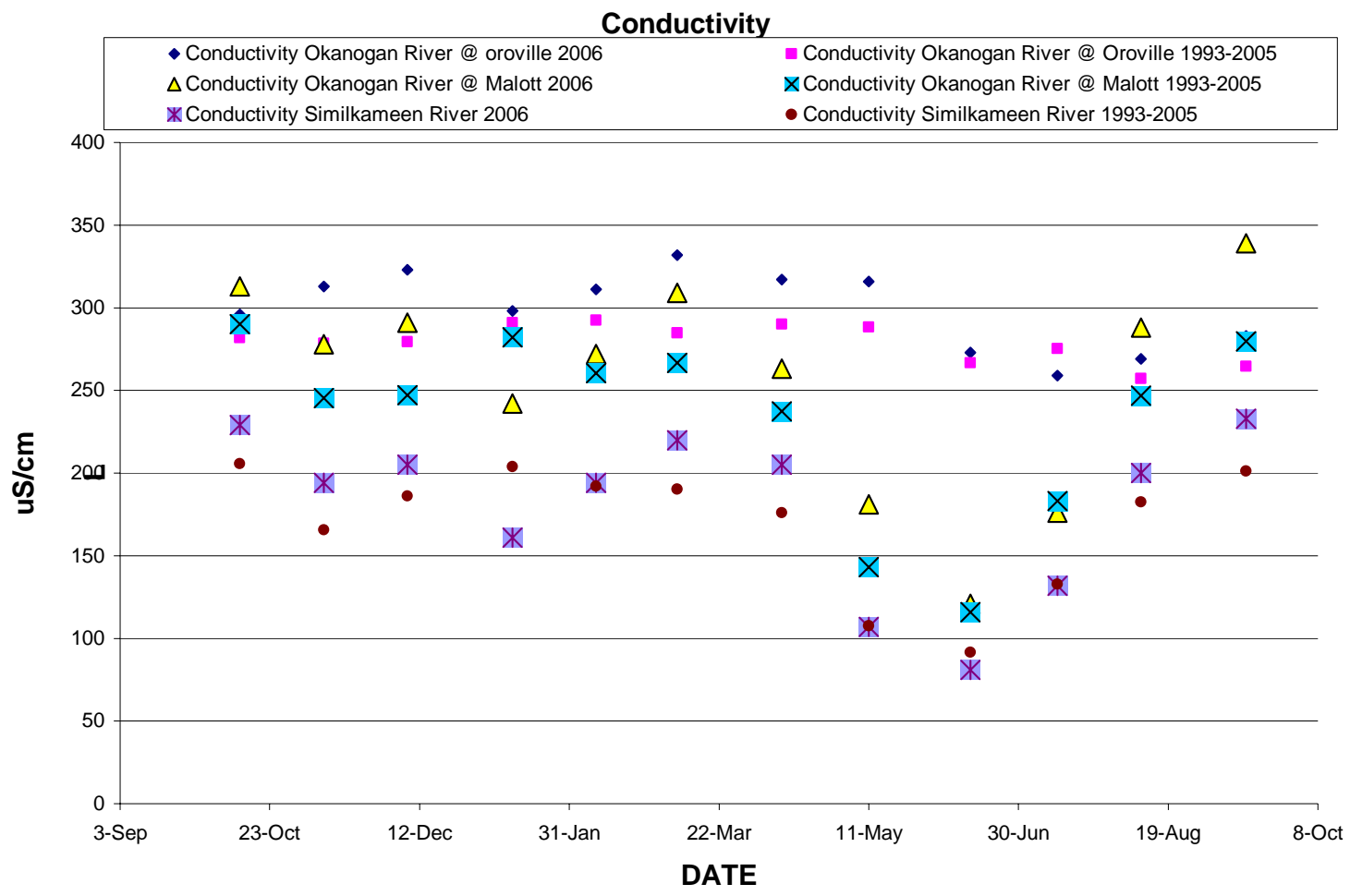

Figure 33. Specific conductivity levels in 2006 compared to the historic average from 1993 to 2005 at WDOE sites along the Okanogan and Similkameen rivers.

\section{Conductivity 12 Year Trend in the Okanogan and Similkameen Rivers}

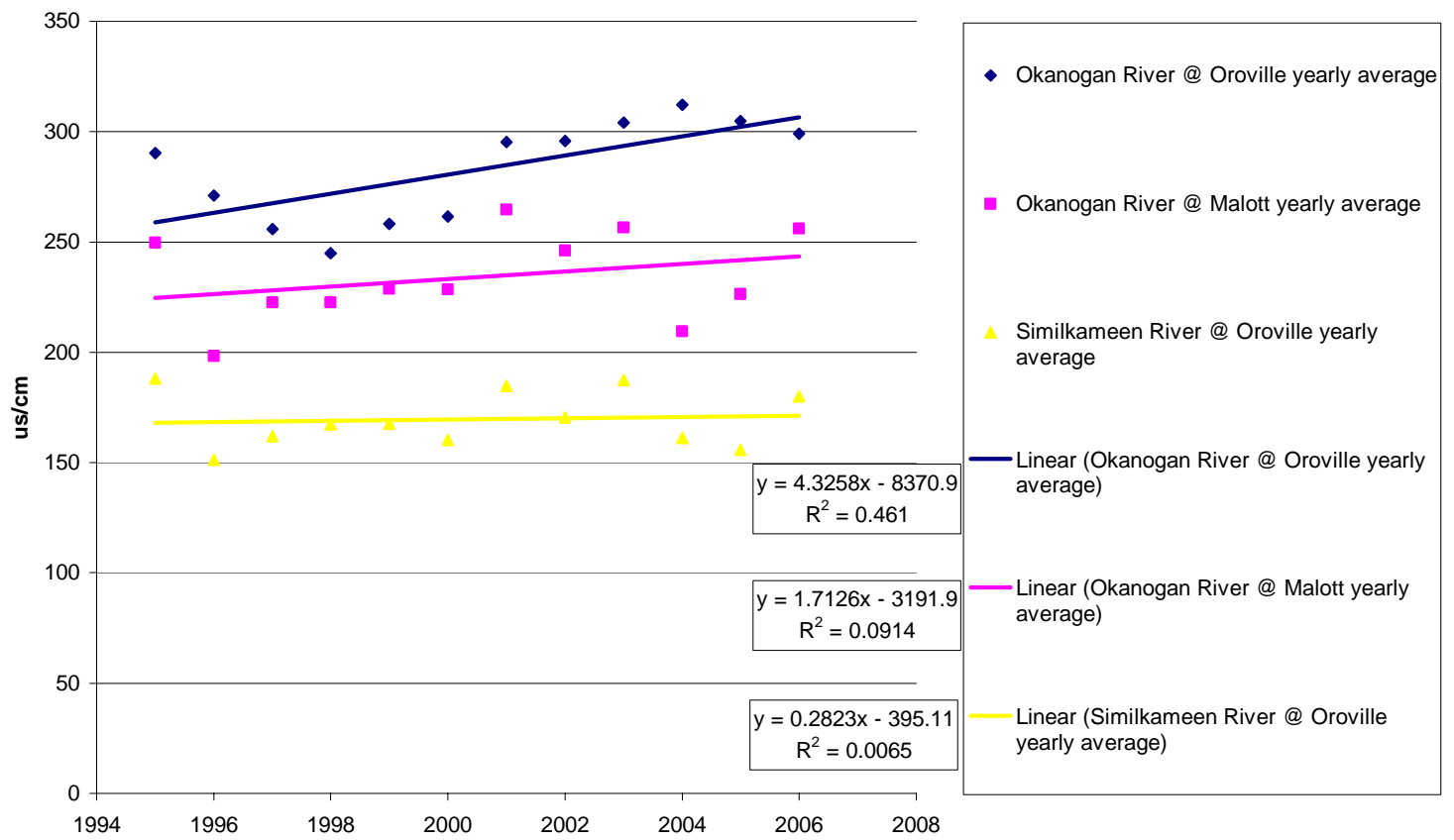

Figure 34. Mean annual data for conductivity trends during the last 12 years from 1995 to 2006 for WDOE sites located along the Okanogan and Similkameen rivers. 


\section{Conductivity-Tributary Status}

We collected additional conductivity data at OBMEP tributary sites located throughout the Okanogan River basin in 2006 (Figure 35). Tributaries to the Okanogan River showed a great deal of variability in specific conductivity readings. The lowest reading was $50 \mu \mathrm{S} / \mathrm{cm}$ at Bonaparte Creek in December. The highest reading was $960 \mu \mathrm{S} / \mathrm{cm}$ at Tonasket Creek in April. The pattern in the data showed that most tributaries peaked in February and March and had their lowest levels in June.
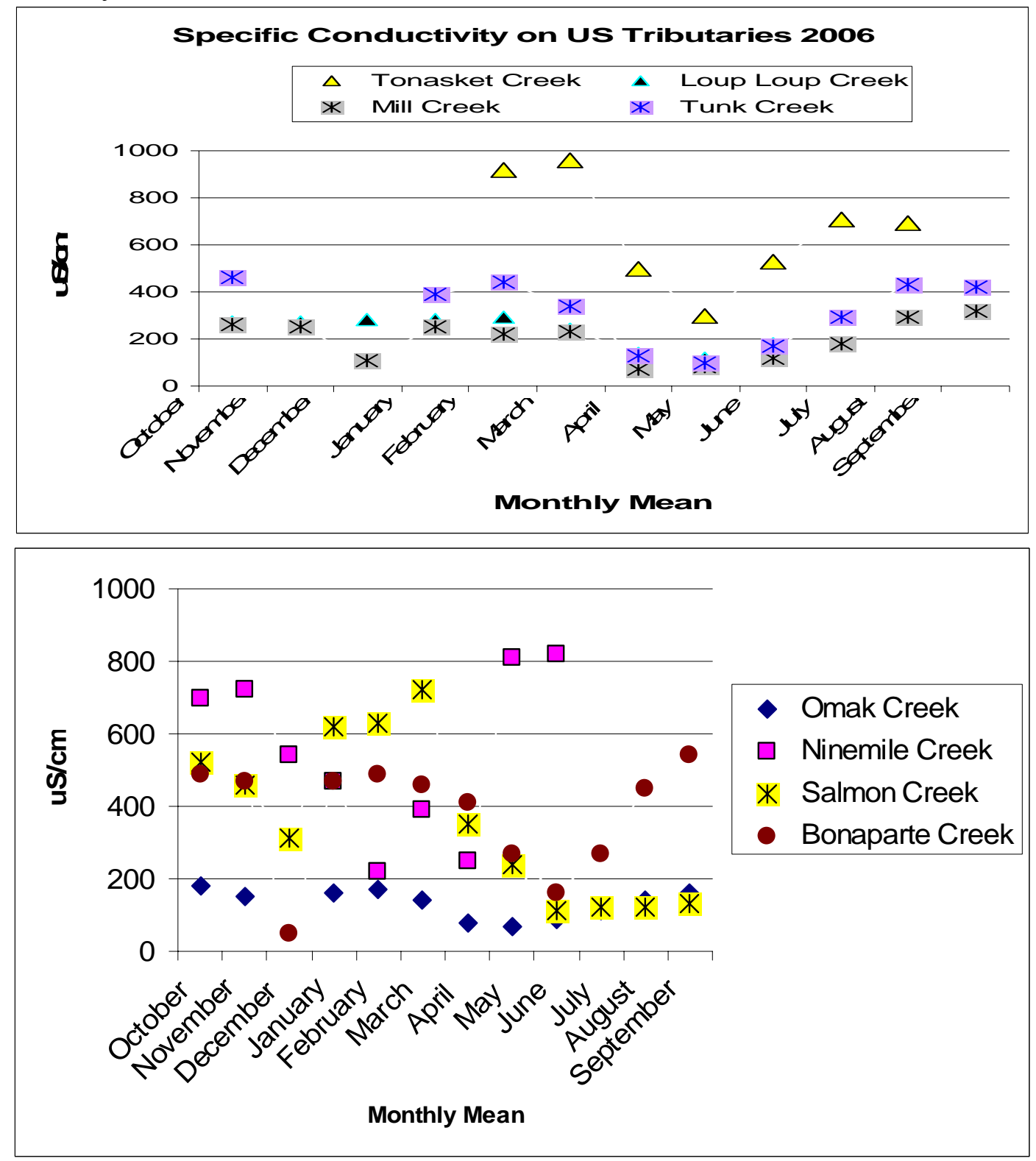

Figure 35. Mean monthly specific conductivity values for 8 tributary sub watersheds within the Okanogan River basin derived from data collected by the Colville Tribes during 2006.

\section{Temperature}

Temperature data was collected by the Colville Tribes Fish and Wildlife Department near the Town of Malott, WA on the Okanogan River using Onset temperature data loggers 
that recorded mean temperature data once every hour from 1995 through 2004. However, data loggers were removed each winter to avoid damage therefore little data exists from the end of January to the middle of March. Starting in 2005 the OBMEP project provided funding to enhance the USGS stream gauging station to include real-time temperature data collection and these data are collected once every 15-minutes year round (http://waterdata.usgs.gov/nwis/uv?12439500). For our analysis we averaged all hourly or 15-minute data into mean daily average temperatures as this is the most commonly used measure of temperature reported in the research literature. A comprehensive temperature document will be completed in 2008 that will analyze real-time, hourly temperature readings collected by the USGS, Environment Canada and the Colville Tribes from many sites throughout the Okanogan River basin.

Salmonids exhibit avoidance behavior for waters that are warmer than $20^{\circ} \mathrm{C}$ while temperatures above $21^{\circ} \mathrm{C}$ are known to be stressful to most salmonids and this occurs in most years. Salmonids will begin to delay migration into rivers once temperatures reach $21^{\circ} \mathrm{C}$ and OBMEP video data suggests that migration will be completely halted once temperatures exceed $24^{\circ} \mathrm{C}$. Direct mortality begins to occur at temperatures above $25^{\circ} \mathrm{C}$ (Jenkins and Burkhead 1993).

In the Okanogan River subbasin summer migrants can encounter a condition termed "The Similkameen Trap". This trap is set-up when rapidly warming waters exiting Canada in the upper Okanogan River reach $24^{\circ} \mathrm{C}$ prior to the Similkameen River. Because fish try to avoid these warm water conditions the fish that enter the Okanogan River prior to the thermal barrier occurring in the Lower Okanogan River below Malott, WA become "trapped" above the confluence with the upper Okanogan and Similkameen Rivers. Early arriving migrants are more susceptible to becoming trapped and in some years high pre-spawn mortality has occurred to both Chinook and sockeye salmon. Pre-spawn mortality typically occurs when fish are trapped for extended periods or during periods of very warm water temperatures on the Similkameen River below Enloe Dam. Fish that arrive later and remain in the Columbia River until such time as temperature conditions favor migration in September (Figure 36) typically avoid any negative effects of the Similkameen Trap.

\section{Temperature-Main-stem Status and Trend}

The historical data from 1995 to 2005 indicates that lower water temperatures likely occur during the months of December through February and high summer water temperatures occur from late June to early September. During 2006, temperatures of $0^{\circ} \mathrm{C}$ were recorded through most of the month of December followed by rapid warming in March and June. Water temperatures exceeded $22^{\circ} \mathrm{C}$ starting on June $27^{\text {th }}$ and continued above this point until the end of July. In 2006, the Okanogan River at Malott had a peak mean daily temperature on $7 / 25 / 2006$ of $27.7^{\circ} \mathrm{C}$. In 2006 , average daily temperatures exceeded $25^{\circ} \mathrm{C}$ for eight days in July at the Malott site. Temperatures hovered around $22^{\circ} \mathrm{C}$ until August $27^{\text {th }}$ when the temperatures declined below this threshold for good (Figure 36). Mild summer air temperatures throughout the months of August and September likely resulted from major forest fires that burned locally throughout this period. The fires produced dense smoke clouds that blocked the suns rays and reduced air temperatures and thermal inputs. 
We were able to construct a 10 year trend for temperature for the Okanogan River site located at Malott, WA (Figure 37). In order to develop this trend requires struggling with several issues; 1) Defining a period that is biologically important to salmonids, 2) Determining the magnitude of the indicator of biological significance; and 3) how to most transparently present the trend information. To do this we looked at many possible alternatives. We chose to focus on the delayed migration of adult salmon that occurs when temperatures exceed $22^{\circ} \mathrm{C}$. This has been a well documented problem in the Okanogan subbasin for many years (Hyatt et al. 2003). As the salmon experience more days of delayed migration the probability that they will successfully spawn is reduced.

Over the last 10 years delays in migration have increased at a rate of 1.82 days per year due to increased warm water temperatures. Increases in water temperature can be linked to many anthropogenic activities such as building reservoirs that release only warm surface water during summer months, reduced stream sinuosity and riparian shading, reduced cold water inputs from spring development and diversion of coldwater tributaries, and climate change brought on by fossil fuel burning and other industrial waste products. Increasing water temperatures within the Okanogan River watershed represent the single most limiting factor facing salmonids in main-stem habitats.

Tributary habitats are more limited by a lack of water and both indicators represent critical items for monitoring habitats related to salmonids today and into the foreseeable future.

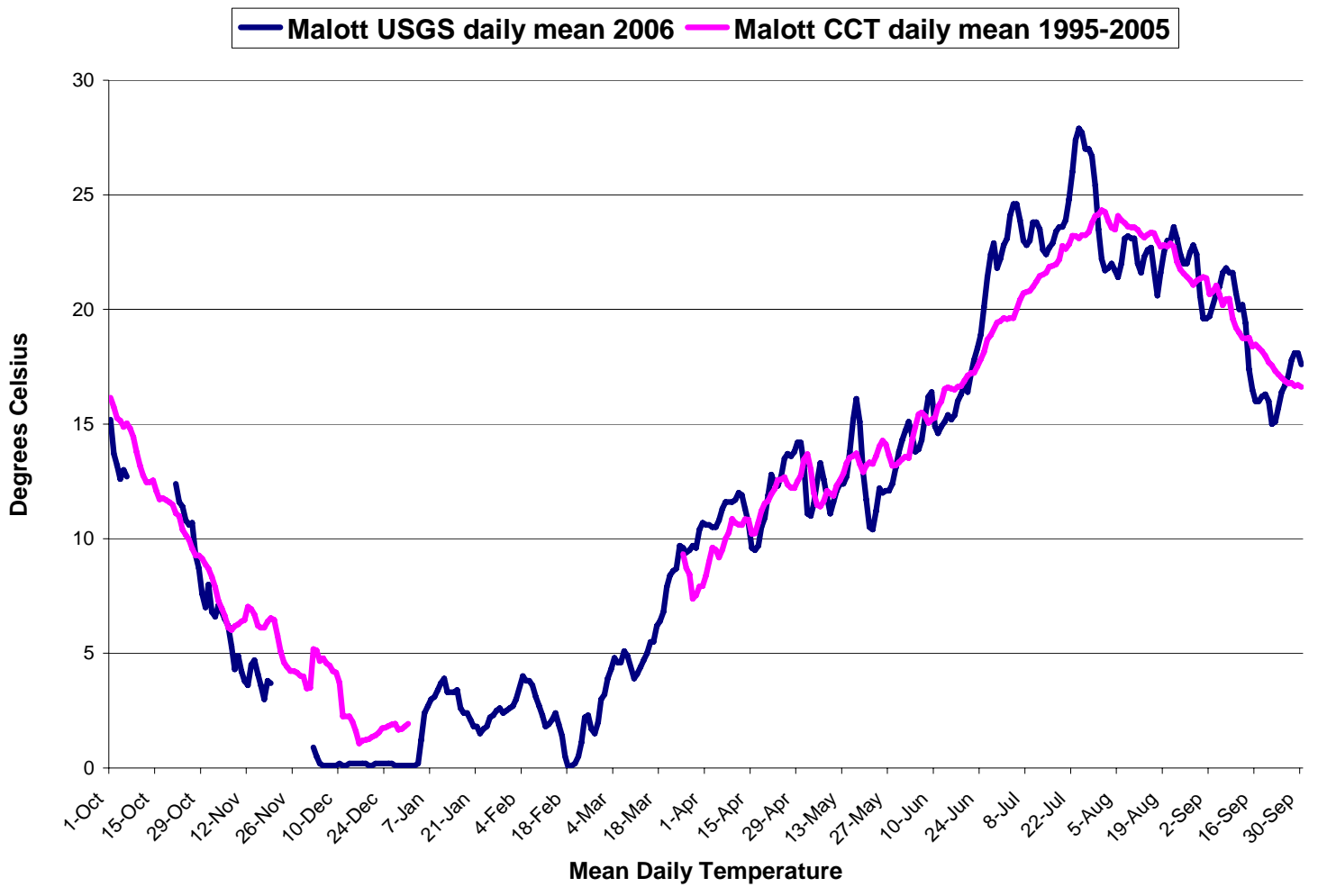

Figure 36: Mean daily temperature data comparing the historic average from 1995 through 2005 to 2006 on the Okanogan River near the town of Malott, WA. Missing data in 2006 is from equipment malfunctions. 


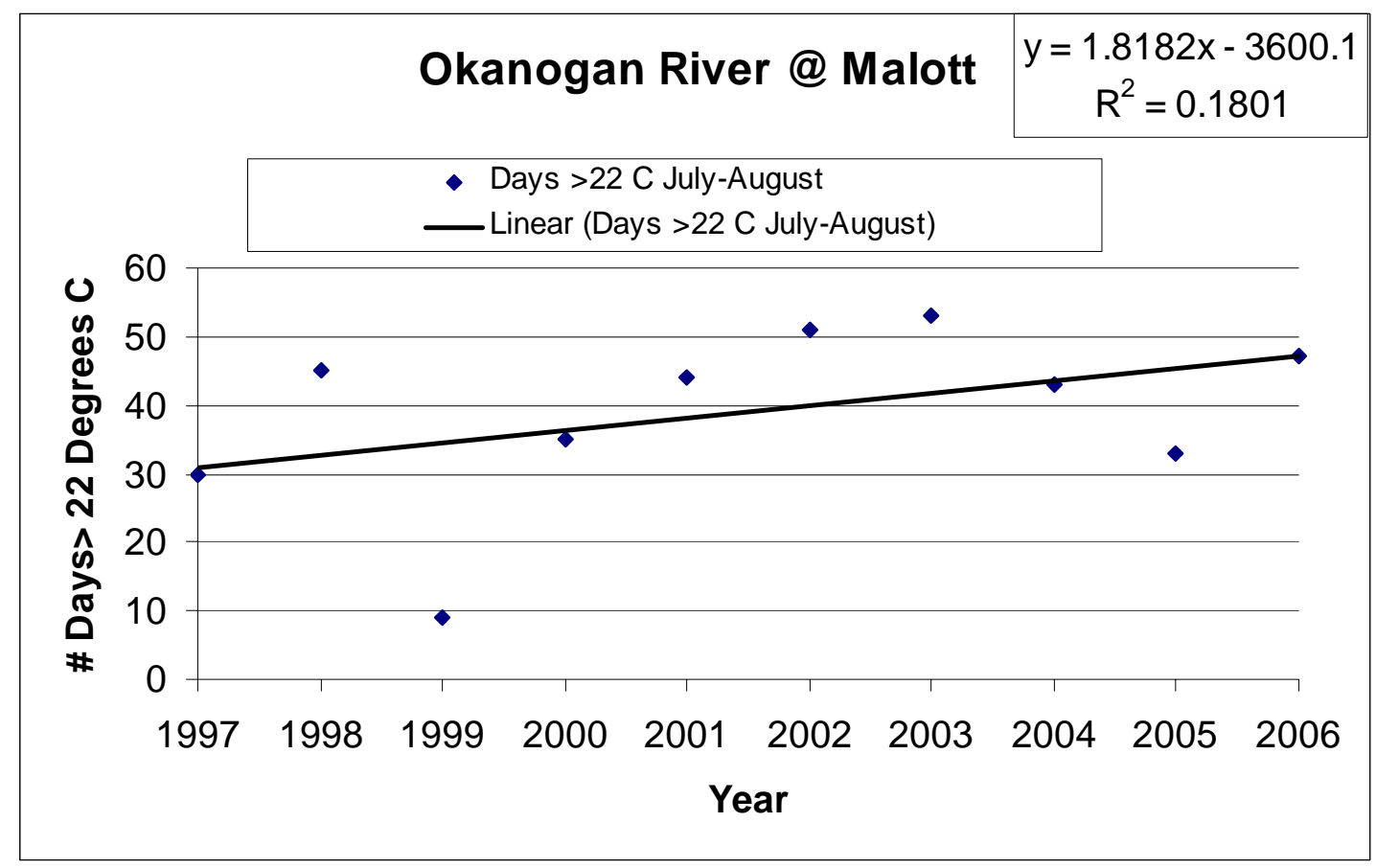

Figure 37: The number of days that migration is delayed into the Okanogan River over the last 10 years assuming migration becomes delayed at 22 degrees Celsius.

\section{Conclusions}

The OBMEP staff complied data collected by the USGS, WDOE and Environment Canada in addition to collecting there own data using Eureka Manta water quality probes. Results from compiled data were more consistent and reliable than the data collected with the water quality probes. The water quality probes were not as maintenance free as we had hoped. During initial data collection we relied on calibrating the probes once every few months. We noticed there was a need for more calibration due to inaccurate readings. In the future we would recommend that we collect water quality samples and have them analyzed at a water quality lab for the best data results. If that option is deemed cost prohibitive we recommend a more rigorous calibration schedule so the readings we do get from the probes are more accurate and reliable. Regardless of these and other technological glitches, the water quality data presented in this report represents the best available information related to salmonid survival and productivity for the Okanogan River basin to date.

Our results showed peak discharge in United States tributaries and Okanogan main-stem sites in 2006 to be higher than average peak flows from previous years sampled. 2006 was an abundant water year. In the Similkameen River, 2006 dischargs was nearly twice as high when compared to the average discharge from the previous four years. Peak flows in 2006 were a month earlier (May) then average peak flows. All 12 year trends for the main stem Okanogan and Similkameen had what appeared to be a slightly decreasing trend. The greatest decrease over 12 years was on the Okanogan River at Malott. This decreasing trend in discharge is not beneficial for salmonid production and efforts to reverse this trend should be strongly encouraged. 
Dissolved oxygen levels were within the low end of acceptable limits for healthy salmonid reproduction, hatching and rearing. We found that for the past 12 years dissolved oxygen levels have been on a slightly downward trend during summer/fall Chinook egg incubation. Trends in decreasing dissolved oxygen levels are consistent with trends in increasing temperature and are therefore likely covariates.

Turbidity levels were only a concern on the Similkameen and some of the Okanagon River tributaries, as they reached 70-90NTUs during spring runoff. This had the potential of reducing primary productivity but also may act as a catalyst for smolt outmigration. The Okanogan River site at Malott and the sampling site on the Similkameen River at Oroville had a marginally detectable decreasing 12 year trend in turbidity. However, these data were highly variable and appear to be influenced by the magnitude of spring runoff.

The $\mathrm{pH}$ values lack much fluctuation between space and over time which indicates that the Okanogan River basin has excellent buffering characteristics that protect it from fluctuating $\mathrm{pH}$ levels. The 12 year trends for $\mathrm{pH}$ indicate that levels are remaining stable along the entire Okanogan River. However, within the Similkameen drainage dramatic annual changes in the mean $\mathrm{pH}$ values have occurred resulting in a declining trend for $\mathrm{pH}$.

Ammonia, nitrogen and phosphorous levels on the mainstem Okanogan and Similkameen Rivers were all within acceptable values for healthy salmonid populations. After assembling 12-years of status data for this indicator at WDOE sites ammonia levels have been well below any levels of biological importance to salmonids, this brings into question the value of continued monitoring for this indicator within this watershed. Over the past 12 years the ratio of $\mathrm{N}$ : P has moved toward a more nitrogen limiting system.

Conductivity levels were similar on the mainstem Okanogan and Similkameen when comparing the historic 12 year averages versus the data for 2006. We had uncertainty about high readings that exceeded $800 \mu \mathrm{S} / \mathrm{cm}$ for Ninemile Creek during May and June and readings over $900 \mu \mathrm{S} / \mathrm{cm}$ for Tonasket Creek which occurred in March and April. Both of these creeks are near the border of Washington and Canada and appear to contain higher levels of inorganic compounds than other creeks throughout the basin but the exact cause for these high readings remains unknown. However, it is unlikely that the levels documented and rates of change in conductivity throughout the Okanogan River subbasin will have any meaningful impact on salmonid survival or production.

Temperature is one of the main limiting factors for salmonid production in the Okanogan River basin. Temperature on the mainstem Okanogan River in 2006 peaked at over $25^{\circ} \mathrm{C}$ at Malott in July and August for eight days. Temperatures similar to these are normal during the warm summer months and salmonids have adapted to avoid these temperatures by waiting in the Columbia River until temperatures cool in early September. Trends indicate that adult salmon are being increasingly delayed when attempting to migrate into the Okanogan River due to increasing water temperatures. Future water quality monitoring efforts in the Okanogan River Basin should focus on temperature and discharge, as they are found to be the main limiting factors for salmonid health in the basin. 


\section{$\underline{\text { Literature Cited }}$}

Arterburn, J. E., K. Kistler, C. Fisher, M.Rayton. 2007. 2007 Okanogan Basin Steelhead Spawning Ground Surveys. BPA project \#200302200. Colville Confederated Tribes Fish and Wildlife Department. Nespelem, WA.

Arterburn, J. E., K. Kistler, M. Rayton. 2006b. 2005 Okanogan Basin Monitoring and Evaluation Program Annual Report. BPA project \#200302200. Colville Confederated Tribes Fish and Wildlife Department. Nespelem, WA.

Arterburn, J. E., K. Kistler. 2006. 2006 Okanogan Basin Steelhead Spawning Ground Surveys. BPA project \#200302200. Colville Confederated Tribes Fish and Wildlife Department. Nespelem, WA.

Arterburn, J. E., K. Kistler, P. Wagner, J. Nuggent, and R. Dasher 2006a. Field Manual for the Okanogan basin Monitoring and Evaluation Program. Habitat Protocol, Version 6/16/2006. http://nrd.colvilletribes.com/obmep/pdfs/Draft\%20Physical\%20Habitat\%20Protoc ols\%2006\%202.pdf

Arterburn, J. E., K. Kistler. 2005. 2004 Okanogan Basin Monitoring and Evaluation Program Annual Report. BPA project \#200302200. Colville Confederated Tribes Fish and Wildlife Department. Nespelem, WA.

Arterburn, J. E., K. Kistler, and M. Rayton 2005a. Field Manual for the Okanogan basin Monitoring and Evaluation Program. Water Quality Sampling Protocols, Version $11 / 23 / 2005$. http://nrd.colvilletribes.com/obmep/pdfs/Draft $\% 20$ water $\% 20$ quality $\% 20$ Protocols .$p d f$

Arterburn, J. E., K. Kistler, P. Wagner, and R. Dasher 2005b. Field Manual for the Okanogan basin Monitoring and Evaluation Program. Biological Protocols, Version 05/25/2005. http://nrd.colvilletribes.com/obmep/pdfs/Draft $\% 20$ Biological\%20Protocols\%20_2 .pdf

Arterburn, J. E., K. Kistler, and R. Dasher. 2005c. 2005 Okanogan Basin Steelhead Spawning Ground Surveys. BPA project \#200302200. Colville Confederated Tribes Fish and Wildlife Department. Nespelem, WA.

Benson, R, M. Squakin and K. Wodchyc. 2006. Okanogan Basin Monitoring and Evaluation Program (OBMEP) 2006 Annual Report for sites in Canada Prepared by the Okanagan Nation Alliance Fisheries Department, Westbank, BC. http://nrd.colvilletribes.com/obmep/pdfs/OBMEP $\% 20$ Annual $\% 20$ Report $06 \% 20 \mathrm{FI}$ NAL.pdf 
Bisson, P. A. and R.E. Bilby. 1982. Avoidance of suspended sediment by juvenile coho salmon. North American Journal of Fisheries Management. 2 (4):371-374.

Bjornn, T. C., and D. W. Reiser. 1991. Habitat requirements of salmonids in streams. American Fisheries Society Special Publication 19: 83-138.

Burrows, R.E. 1964. Effects of acclimated excretory products on hatchery-reared salmonids, Washington DC, Fish and Wildlife Service, US Department of the Interior, $12 \mathrm{pp}$ (Research Report 66).

Butkus, S. 2005. Quality Assurance Monitoring Plan, Streamflow Gauging Network. Washington State Department of Ecology, Publication Number 05-03-304 http://www.ecy.wa.gov/biblio/0503204.html

Davis, J. C. 1975. Minimal dissolved oxygen requirements of aquatic life with emphasis on Canadian species: a review. Journal of the Fisheries Research Board of Canada 32:2295-2332.

Hyatt, K. D., M. M. Stockwell, and D. P. Rankin. 2003. Impact and adaptation responses of Okanogan River sockeye salmon (Oncorhynchus nerka) to climate variation and change effects during freshwater migration: stock restoration and fisheries management implications.

Jenkins, R. E., and N. M. Burkhead. 1993. Freshwater fishes of Virginia. American Fisheries Society, Bethesda, MD.

Kistler K., and J. Arterburn. 2007. 2006 Okanogan Basin Snorkel Survey Report. BPA project \#200302200. Colville Confederated Tribes Fish and Wildlife Department. Nespelem, WA

Kistler K, and J. Arterburn. 2007. 2006 Steelhead Spawning Ground Surveys, Final Report. Bonneville Power Administration Department of Fish and Wildlife, Portland, Oregon.

Kistler K., and J. Arterburn. 2006. 2005 Okanogan Basin Snorkel Survey Report. BPA project \#200302200. Colville Confederated Tribes Fish and Wildlife Department. Nespelem, WA.

Kresch, D. and S. Tomilson. 2004. Surface-Water Quality-Assurance Plan for the Washington District, U.S. Geological Survey, Water Resources Discipline. U.S. Geological Survey, Open-File Report 03-490 Version Number 1.10, September 2004.

LaPerriere, J. D., and 5 coauthors. 1983. Effects of gold placer mining on interior Alaska stream ecosystems. Pages 12/1-12/34 in j. w. Aldrich, editor. Managing water resources for Alaska's development. University of Alaska, Institute of water resources report IWR-105, Fairbanks, AK. 
Lloyd, D.S. 1987. Turbidity as a water quality standard for salmonid habitat in Alaska. North American Journal of Fisheries management 7: 34-45.

Norris, L. A., H. W. Lorz, and S. V. Gregory, 1991. Forest Chemicals. American Fisheries Society Publication 19:207-295.

Piper, Robert G.,et. al. 1982. Fish Hatchery Management. US Department of the Interior, Fish and Wildlife Service, Washington D.C.

Russo, R. C., V. R. Thurston, and K. Emerson. 1981. Acute toxicity of nitrite to rainbow trout (salmon gairdneri): effects of $\mathrm{pH}$, nitrite species, and anion species. Canadian Journal of Fisheries and Aquatic Sciences 38:387-393.

Russo, R. C., V. R. Thurston. 1991. Toxicity of ammonia, nitrite, and nitrate to fishes. Pages 58-89 in D.E. Brune and J. R. Tomasso, editors. Aquaculture and water quality. World Aquaculture Society, Baton Rouge, LA..

Reynolds, J. B. 1996. Electrofishing. Pages 221-253 in: B. R. Murphy and D. W. Willis, editors. Fisheries techniques, $2^{\text {nd }}$ edition. American Fisheries Society, Bethesda, MD.

Sigler, J.W. 1984. Effects of chronic turbidity on density and growth of steelhead and coho salmon. Transactions of the American Fisheries Society 113: 142-150.

Sorenson, D. L., M. M. McCarthy, E. J. Middlebrooks, and D. B. Porcella. 1977. Suspended and dissolved solids effects on freshwater biota. U. S. Environmental Protection Agency, EPA-600/3-77-042.

Summerfelt, S., J. Bebak-Williams, and S. Tsukuda. 2001. Controlled systems: water reuse and circulation. Pages 285-395 in G. A, Wedemeyer, editor. Fish hatchery management, second edition. American Fisheries Society, Bethesda, MD.

Wedemeyer, Gary A. 1996. Physiology of Fish in Intensive Culture Systems. Chapman Hall, New York, New York. 